FELIPE GRABARZ

CÉLULAS NKT, MACRÓFAGOS M2 E O DESENVOLVIMENTO DA FIBROSE PULMONAR

Dissertação apresentada ao Programa de Pós-Graduação em Imunologia do Instituto de Ciências Biomédicas da Universidade de São Paulo para obtenção do Título de Mestre 
FELIPE GRABARZ

\section{CÉLULAS NKT, MACRÓFAgOS M2 E O DESENVOLVIMENTO DA FIBROSE PULMONAR}

\footnotetext{
Dissertação apresentada ao Programa de Pós-Graduação em Imunologia do Instituto de Ciências Biomédicas da Universidade de São Paulo para obtenção do Título de Mestre Área de Concentração: Imunologia Celular e Molecular

Orientador: Prof. Dr. Niels Olsen Saraiva Câmara

Versão original
} 
DADOS DE CATALOGAÇÃO NA PUBLICAÇÃO (CIP)

Serviço de Biblioteca e Informação Biomédica do

Instituto de Ciências Biomédicas da Universidade de São Paulo

(c) reprodução total

Grabarz, Felipe.

Células NKT, macrófagos M2 e o desenvolvimento da fibrose pulmonar / Felipe Grabarz. -- São Paulo, 2014.

Orientador: Prof. Dr. Niels Olsen Saraiva Câmara.

Dissertação (Mestrado) - Universidade de São Paulo. Instituto de Ciências Biomédicas. Departamento de Imunologia. Área de concentração: Imunologia. Linha de pesquisa: Inflamação, regulação Th1/Th2, fenotipagem celular.

Versão do título para o inglês: NKT Cells, M2 Macrophages and the development of pulmonary fibrosis.

$\begin{array}{llll}\text { 1. Bleomicina } & \text { 2. Células NKT } & \text { 3. Macrófagos M2 4. Fibrose }\end{array}$ Pulmonar I. Câmara, Prof. Dr. Niels Olsen Saraiva II. Universidade de São Paulo. Instituto de Ciências Biomédicas. Programa de PósGraduação em Imunologia III. Título. 
Candidato(a):

Título da Dissertação:
Felipe Grabarz.

Células NKT, macrófagos M2 e o desenvolvimento da fibrose pulmonar.

Orientador(a):

Prof. Dr. Niels Olsen Saraiva Câmara.

A Comissão Julgadora dos trabalhos de Defesa da Dissertação de Mestrado, em sessão pública realizada a ................, considerou
( ) Aprovado(a)
( ) Reprovado(a)

Examinador(a): Assinatura:

Nome:

Instituição:

Examinador(a): Assinatura:

Nome:

Instituição:

Presidente: Assinatura:

Nome:

Instituição: 


\section{UNIVERSIDADE DE SÃO PAULO \\ INSTITUTO DE CIÊNCIAS BIOMÉDICAS}

Cidade Universitária "Armando de Salles Oliveira"

Av. Prof. Lineu Prestes, 2415 - CEP. 05508-000 São Paulo, SP - Brasil

Telefone :(55) (011) 3091.7733 - e-mail: ceplicb.usp.br

\section{Certificado}

Certificamos que o protocolo registrado sob $n^{\circ} 135$ nas fls. 94 do livro 02 para uso de animais em experimentação, sob a responsabilidade do Prof(a) Dr(a) Niels Olsen Saraiva Câmara, Coordenador(a) da Linha de pesquisa Efeito da HO-1 sobre o desenvolvimento da fibrose pulmonar induzida pela bleomicina em camundongos deficientes em cêlulas NKT invariantes do qual participam o(s) alunos Felipe Grabarz e os pesquisadores Mariastela de Almeida Vitta Landgraf, Ricardt Gama Landgraf, está de acordo com os Principios Éticos de Experimentação Animal adotado pela Sociedade Brasileira de Ciência de Animais de Laboratório (SBCAL) e foi aprovado pela COMISSÃO DE ÉTICA NO USO DE ANIMAIS (CEUA) em 08.12.2010, com validade de 3 anos.

São Paulo, 08 de dezembro de 2010.
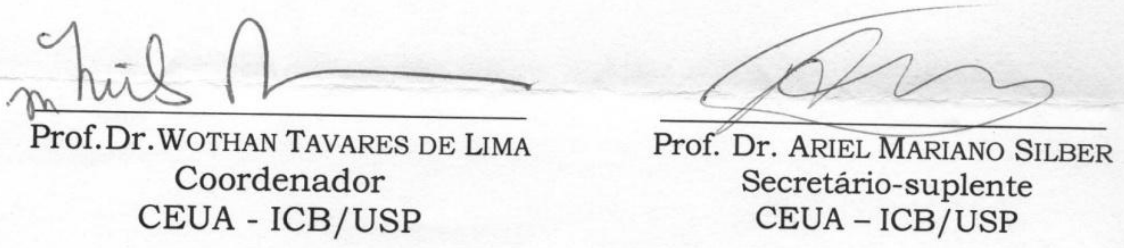


\section{Certificado}

Certificamos que o protocolo registrado sob $n^{\circ} \mathbf{0 2 0}$ nas fls. 03 do livro 03 para uso de animais em experimentação, sob a responsabilidade do Prof(a) $\operatorname{Dr}(\mathrm{a})$ ) Niels Olsen

Saraiva Câmara, Coordenador (a) da Linha de pesquisa "Células NKT, macrófagos M2 e o desenvolvimento da fibrose pulmonar" do qual participam o(s) aluno(s)Felipe Grabarz, Vinicius Andrade, Tárcio Teodoro Braga, está de acordo com os Princípios Éticos de Experimentação Animal adotado pela Sociedade Brasileira de Ciência de Animais de Laboratório (SBCAL) e foi aprovado pela COMISSÃO DE ÉTICA NO USO DE ANIMAIS (CEUA) em 17.05.2013, com validade de 4 anos.

São Paulo, 22 de maio de 2013.

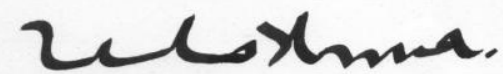

Prof. Dr. WOTHAN TAVARES DE LIMA Coordenador-CEUA - ICB/USP

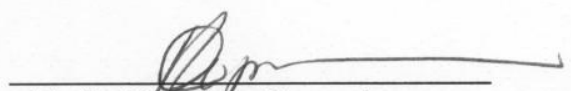

Profa. Dra. ANa PAULA LePIQUE Secretária- CEUA - ICB/USP 


\section{AGRADECIMENTOS}

A meus pais, Judite e Moises, por me apoiarem em minhas decisões e me darem o suporte que eu preciso;

Ao meu grande amigo e irmão, Allan, por conversas inspiradoras e pela ajuda contínua na batalha da vida;

À minha namorada, Anna que sempre esteve do meu lado, oferecendo ajuda e paciência e a toda a família Sfreddo.

Ao Professor Niels, por confiar em mim e me dar esta oportunidade e orientação; Ao Professor Benedito Corrêa e à Tatiana Alves Correia, por fazerem parte da minha trajetória científica;

À minha prima Renata, que considero minha segunda orientadora e sempre me ajudou muito;

Ao meu Professor Alexandre Lourenço por me apoiar e acreditar no meu potencial; À minha grande amiga Tainah, por ter me trazido ao mundo da pesquisa e ser uma grande amiga e companheira;

À todo o laboratório de Imunobiologia de Transplantes (LIT), por ter me ajudado tanto no desenvolvimento deste projeto;

A Matheus, Tárcio, Flávia, Cris, Maristella, Vinícius, Richardt, Meire, Reinaldo e Marina por terem me ajudado nas mais diversas metodologias, análise de resultados e principalmente, pela paciência;

A Andrea Glatt pela ajuda nos experimentos em Citometria de Fluxo;

Ao Israel, que nunca hesitou em me ajudar no Biotério;

A todos os funcionários do Instituto de Ciências Biomédicas;

A todos que contribuíram de outras formas para o desenvolvimento deste projeto. 
“A resposta certa não importa nada: o essencial é que as perguntas estejam certas." Mario Quintana 


\section{RESUMO}

Grabarz F. Células NKT, macrófagos M2 e o desenvolvimento da fibrose pulmonar. [dissertação (Mestrado em Imunologia)]. São Paulo: Instituto de Ciências Biomédicas, Universidade de São Paulo; 2014.

A fibrose pulmonar é uma via comum de várias doenças agudas e crônicas do interstício pulmonar que pode resultar na cicatrização anormal do pulmão em resposta à lesão do epitélio alveolar. Neste processo, ocorre acúmulo excessivo das proteínas da matriz extracelular (MEC) produzidas, principalmente, pelos fibroblastos e miofibroblastos, levando a desestruturação das paredes alveolares, perda da elasticidade do tecido e consequente perda das funções ventilatórias e de trocas gasosas pelos pulmões. As células NKT são grande fonte de citocinas de padrão Th2 e podem ser cruciais na ativação e polarização de macrófagos para o fenótipo M2, contribuindo na fibrogênese pulmonar. A partir destes fatos, nosso projeto construiu uma hipótese de que as células NKT pudessem influenciar o desenvolvimento de fibrose pulmonar via modulação da ativação de macrófagos. Assim, em um modelo de fibrose pulmonar experimental induzida pela bleomicina, estudamos a interação entre células NKT e macrófagos alveolares. Para isso, animais selvagens e knockout para células NKT invariante (Ja18-/-) foram submetidos ao protocolo de indução de fibrose pulmonar pela bleomicina. As células NKT foram ativadas com dois ligantes diferentes: a $\alpha$-galactosilceramida e o sulfatídeo. A participação de diferentes populações celulares, em especial as células NKT e macrófagos, bem como o infiltrado inflamatório, a produção e a deposição de colágeno e a expressão gênica de citocinas envolvidas em processos de inflamação e fibrose, foram avaliados por citometria de fluxo e qPCR. Os resultados indicam que o grupo Ja18/- assim como os grupos experimentais que receberam agonistas para células NKT apresentaram uma proteção contra a fibrose pulmonar uma vez que houve menor síntese de hidroxiprolina e deposição de colágeno. Nestes grupos, há também a diminuição de citocinas pró-fibróticas e a manutenção de um fenótipo M1 dos macrófagos no tecido pulmonar. Nossos dados sugerem que as células NKT sejam uma das responsáveis em modular o padrão da resposta inflamatória neste modelo experimental, contribuindo para o desenvolvimento da fibrose.

Palavras-chave: Células NKT. Macrófagos M2. Fibrose Pulmonar. Bleomicina. 


\begin{abstract}
Grabarz F. NKT Cells, M2 Macrophages and the Development of Pulmonary Fibrosis. [Masters thesis (Immunology)]. São Paulo: Instituto de Ciências Biomédicas, Universidade de São Paulo; 2014.

Pulmonary fibrosis is a common pathway of various acute and chronic interstitial lung diseases that may result in abnormal wound healing of the lungs in response to damage of the alveolar epithelium. During this process, there is excessive accumulation of extracellular matrix proteins (ECM) produced mainly by fibroblasts and myofibroblasts, leading to disruption of the alveolar walls, loss of tissue elasticity and loss of ventilatory function and gas exchange in the lungs. NKT cells are a major source of Th2 cytokines and may be crucial in the activation and polarization of macrophages to the M2 phenotype, contributing to pulmonary fibrogenesis. From these facts, our project has built a hypothesis that NKT cells could influence the development of pulmonary fibrosis via modulation of macrophage activation. Thus, in an experimental model of pulmonary fibrosis induced by bleomycin, we studied the interaction between NKT cells and alveolar macrophages. For this, wild and knockout invariant NKT cells (Ja18 $\left.{ }^{-/-}\right)$mice were subjected to the protocol of bleomycin induced pulmonary fibrosis. NKT cells were activated with two different ligands: the a-galactosylceramide and sulfatide. Participation of different cell populations, especially NKT cells and macrophages, as well as the inflammatory infiltrate and deposition of collagen production and gene expression of cytokines involved in the inflammation and fibrosis, were evaluated by flow cytometry and qPCR. The results indicate that the Ja18/- mice, as well as the experimental groups receiving agonists for NKT cells, showed protection against lung fibrosis, since there was less hydroxyproline synthesis and deposition of collagen. In these groups, there is also the decrease of pro-fibrotic cytokines and maintaining of the M1 phenotype of macrophages in lung tissue. Our data suggest that NKT cells may be one of the responsible to modulate the pattern of the inflammatory response in this experimental model, contributing to the development of fibrosis.
\end{abstract}

Keywords: NKT Cells. M2 Macrophages. Lung Fibrosis. Bleomycin. 


\section{LISTA DE FIGURAS}

Figura 1. Análise do desenvolvimento da fibrose pulmonar em resposta a instilação intratraqueal da bleomicina 33

Figura 2. Análise histológica da deposição de colágeno no tecido pulmonar 34

Figura 3. Análise do desenvolvimento da fibrose pulmonar induzida pela bleomicina em camundongos WT e Ja18

Figura 4. Análise histológica de deposição de colágeno no tecido pulmonar.

Figura 5. Contagem diferencial de células no BAL..............................................39

Figura 6. Análise de transcrito gênico.................................................................40

Figura 7. Curva de sobrevida .........................................................................41

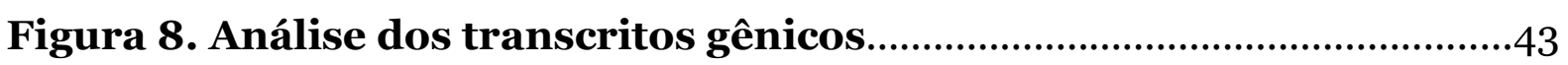

Figura 9. Análise dos transcritos gênicos e quantificação proteica.............44

Figura 10. Análise dos transcritos gênicos e quantificação proteica...........45

Figura 11. Síntese proteica de vimentina no tecido pulmonar......................46

Figura 12. Análise histológica da síntese de Vimentina................................46

Figura 13. Dosagem proteica..........................................................................48

Figura 14. Análise por citometria de fluxo......................................................50

Figura 15. Análise por citometria de fluxo......................................................50

Figura 16. Análise por citometria de fluxo.......................................................51

Figura 17. Análise por citometria de fluxo.................................................

Figura 18. Representação gráfica da análise fenotípica de células TCD4+ e células NKT pelo método de citometria de fluxo...............................................53

Figura 19. Análise de transcritos gênicos..................................................54

Figura 2o. Análise de transcritos gênicos de produtos e fatores de transcrição relacionados a fenótipo e recrutamento macrofágico................55 Figura 21. Representação gráfica da análise fenotípica dos macrófagos pelo método de citometria de fluxo. 


\section{LISTA DE ABREVIATURAS E SÍMBOLOS}

aGalCer: $\alpha$-Galactosilceramida

ADAM: Desintegrinas e Metaloproteases de Membrana

APC: Células Apresentadora de Antígeno

Arg-1: Arginase-1

a-SMA: Alfa Actina de Músculo Liso

BAL: Lavado Broncoalveolar

BSA: Albumina de Soro Bovino

BLM: Bleomicina

CD: Grupo de Diferenciação (cluster of differentiation)

CCL: Ligante de Quimiocina

CXCR3: Receptor de Quimiocina

cDNA: Ácido desoxirribonucleico complementar

C57Bl/6: Camundongo Isogênico 'Black 6'

DAB: Diaminobenzidina

DC: Células Dendríticas

EDTA: Ácido Etilenodiamino Tetra-Acético

FIZZ1: Molécula Semelhante a Resistina Alfa-1

FPI: Fibrose Pulmonar Idiopática

FoxP3: Fator de Transcrição para Células T Regulatórias

HPRT: Hipoxantina-guanina Fosforibosiltransferase

IFN- $\boldsymbol{~}$ : Interferon- $\gamma$

IL: Interleucina

IHQ: Imunohistoquímica

iNKT: Células NKT invariantes

iNOS: Óxido Nítrico Sintase

IRF: Fator Regulatório de Interferon

IP: Intraperitonial

IV: Intravenoso

IT: Intratraqueal

IgE: Imunoglobulina $\mathrm{E}$

Ja18 ${ }^{-/-}$: Camundongos deficientes para células NKT tipo I

KO: Camundongos deficientes 
LPS: Lipopolissacarídeo

mRNA: RNA mensageiro

M1: Macrófagos do tipo M1

M2: Macrófagos do tipo M2

MCP-1: Proteína Quimiotática de Monócitos-1

MEC: Matriz Extra Celular

MHC: Complexo Principal de Histocompatibilidade

MMP: Metaloproteases da Matriz

NK: Células Natural Killers

NKT: Células T Natural Killers

NF-кB: Fator Nuclear Kappa B

NO: Óxido Nítrico

OVA: Ovoalbumina

PBS: Tampão Fosfato-Salino

PCR-RT: Reação de Polimerase em Tempo Real

PDGF: Fator de Crescimento Derivado de Plaquetas

RNA: Ácido Ribonucleico

STAT: Transdutor de Sinal e Ativador de Transcrição

Smad: Proteína envolvida na Transdução de Sinais Intracelulares

TBS: Tampão Tris-Salina

TCR: Receptor de Célula T

Th: Células T Helper

TLR: Receptores do tipo Toll-like

TGF- $\beta$ : Fator Transformador de Crescimento- $\beta$

TIMP: Inibidor Tecidual de Metaloprotease

TNF-a: Fator de Necrose Tumoral- $\alpha$

WT: Camundongo Selvagem 


\section{SUMÁRIO}

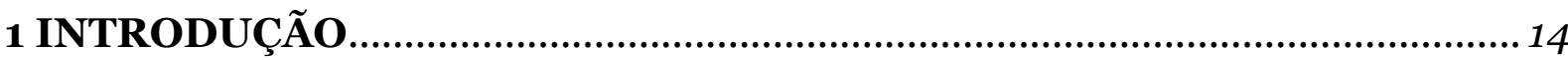

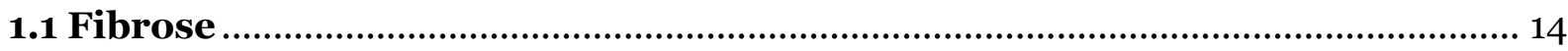

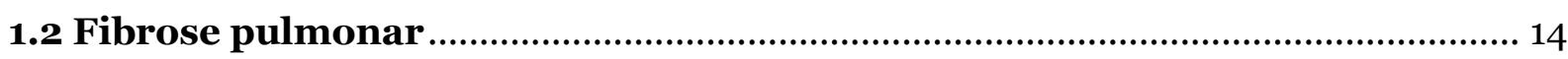

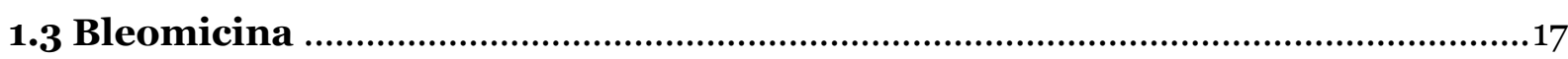

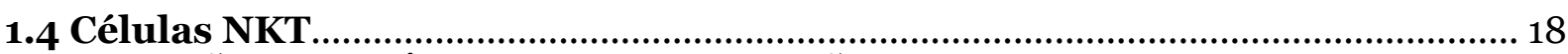

1.4.1 FUNÇÕES DAS CÉLULAS NKT NO PULMÃO E NA FIBROSE PULMONAR …….......... 19

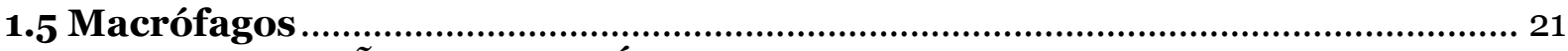

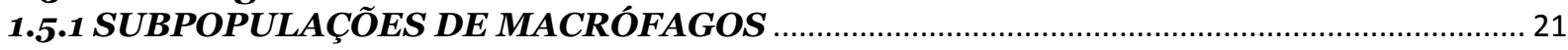

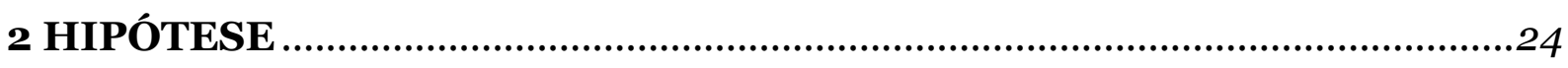

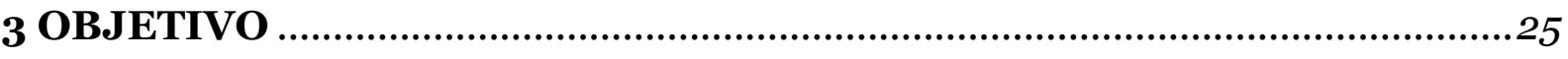

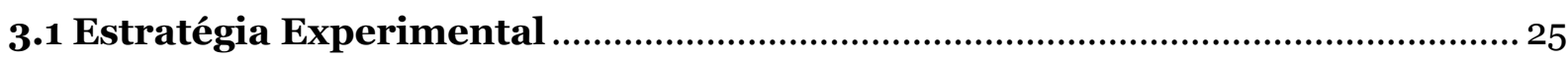

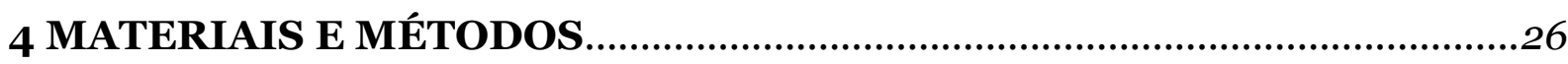

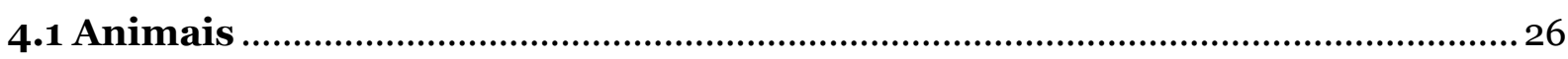

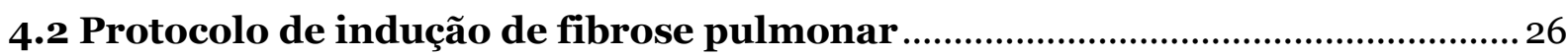

4.3 Administração de a-Galactosilceramida e Sulfatídeo …....................................26

4.4 Obtenção do Lavado Broncoalveolar (BAL) ...................................................... 27

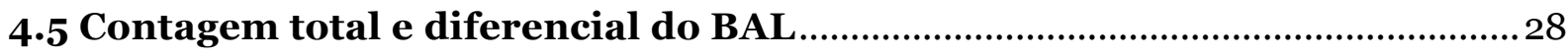

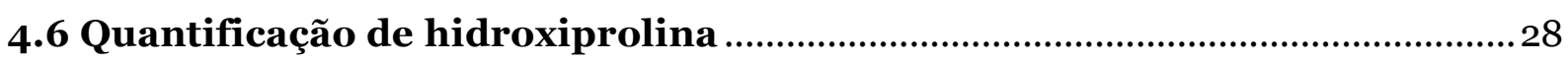

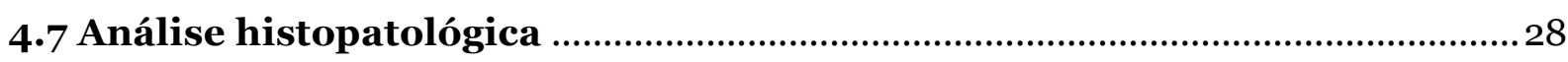

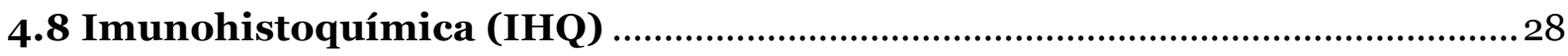

4.9 Extração do RNA total e análise de transcritos gênicos .................................29

4.10 Quantificação proteica por BioPlex …................................................................ 30

4.11 Análise de infiltrado celular por citometria de fluxo ........................................

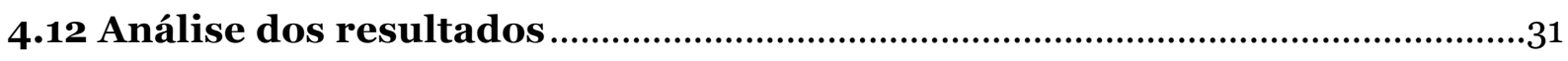

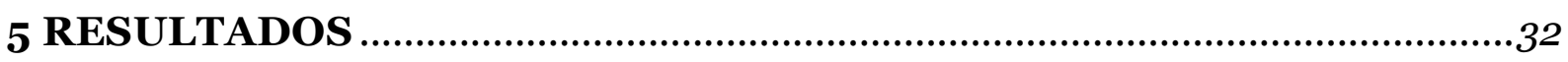

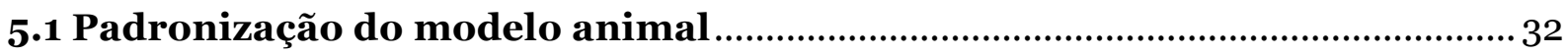

5.2 Análise de parâmetros fibróticos nos grupos experimentais ……….............. 35

5.3 Curva de sobrevida nos grupos experimentais...................................................40

5.4 Transcritos gênicos relacionados à fibrose e a inflamação.............................. 41

5.5 Estratégia de análise para citometria de fluxo ................................................49

5.6 Regulação de padrão Th1/Th2 é em parte mediada por linfócitos T CD4+ $\ldots 52$

5.7 Transcritos gênicos dos fenótipos M1 e M2 nos grupos experimentais ……... 53

5.8 Identificação fenotípica de macrófagos por citometria de fluxo …...................56

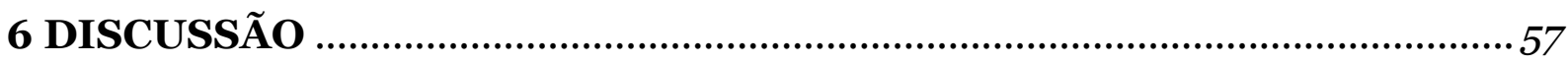

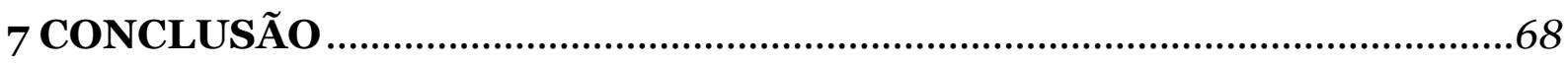

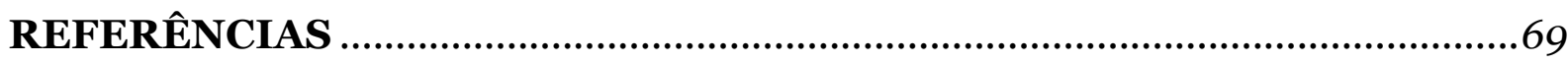




\section{INTRODUÇÃO}

\subsection{Fibrose}

A fibrose é um processo patológico progressivo que acarreta em uma expansão gradual da massa fibrótica, levando à destruição dos tecidos e órgãos envolvidos. No processo fisiológico da cicatrização, há um balanço entre o processo de formação e degradação da matriz extracelular (MEC), que se encontra prejudicado na fibrose. Vários trabalhos indicam que a proliferação de células produtoras da matriz, com consequente superprodução e acúmulo de proteínas da matriz, contribuem para a doença fibrótica [1-6].

\subsection{Fibrose pulmonar}

A fibrose pulmonar é uma doença potencialmente fatal, resultante de doenças agudas e crônicas do interstício pulmonar [7]. Este processo patológico tem sido proposto como resultado da cicatrização anormal do pulmão em reposta à lesão do epitélio alveolar [8], sendo que o acúmulo excessivo das proteínas da MEC, produzidas principalmente pelos fibroblastos e miofibroblastos, é responsável pela desestruturação das paredes alveolares, pela perda da elasticidade do tecido e pelo consequente desenvolvimento do pulmão rígido. A progressão da fibrose pulmonar resulta no aumento da matriz intersticial, com eventual destruição do parênquima pulmonar normal, e danos importantes aos capilares, provocando insuficiência ventilatória [9].

A Fibrose Pulmonar Idiopática (FPI) é a mais comum das pneumonias intersticiais e que também carrega o pior prognóstico [10], levando a óbito de $50 \%$ a 70 \% dos pacientes em até cinco anos após o diagnóstico da doença. A incidência masculina desta patologia tem sido estimada em 10.7 casos por 100.000 pessoas/ano e a incidência feminina, 7.4 casos por 100.000 pessoas/ano. A prevalência da doença é estimada em 29 casos em 100.000 pessoas para população masculina e $27 \mathrm{em}$ 100.0oo pessoas para a população feminina [11]. Em indivíduos afetados, há tosse improdutiva, esforço ao respirar e falta de ar, além da deficiência na função pulmonar, com redução de troca gasosa [12]. 
Apesar de a doença ser de etiologia idiopática, estudos epidemiológicos demonstram diversos fatores de risco (ambientais e ocupacionais) que podem contribuir para o surgimento da doença. A exposição à sílica e areia pode aumentar o risco de desenvolver fibrose pulmonar. Pó de metais pesados, como o níquel, silício e alumínio, também parecem ter um papel importante no desenvolvimento da doença. Trabalho realizado no campo, como agricultura e pecuária, são mencionados como fatores para o desenvolvimento da FPI [13]. Além disso, infecções virais, exposição à radioterapia, quimioterapia e toxinas ambientais que podem ser inaladas contribuem para o aparecimento da doença. Outros fatores de risco envolvem o transplante de medula óssea, quando ocorre a doença do enxerto contra o hospedeiro, além de pacientes com esclerodermia e artrite reumatoide [14], demonstrando o amplo espectro na qual a FPI pode surgir.

O processo da progressão da fibrose pulmonar pode ser dividido em três eventos gerais: eventos desencadeadores iniciais, eventos inflamatórios e eventos fibróticos. Estas fases, por vezes, se sobrepõem [9].

1. Eventos desencadeadores iniciais: as causas da fibrose são diversas e incluem vapores tóxicos, poeiras inorgânicas, drogas, fatores genéticos e radiação, além de outros fatores não identificados (idiopáticos) [11]. Estes estímulos lesivos podem desencadear a ativação ou lesão das células epiteliais alveolares, levando a reações inflamatórias no interstício. Células inflamatórias e residentes induzem a produção/liberação de vários fatores mitogênicos e fibrogênicos, que atuam sobre as células intersticiais, provocando a sua proliferação, diferenciação e consequente liberação de citocinas e fatores de crescimento, que contribuem para a produção de cicatriz ou formação do tecido colagenoso em resposta e este dano (Figura 1).

2. Eventos inflamatórios: nesta fase, as células do epitélio alveolar lesionadas atuam junto a outras células residentes, liberando mediadores inflamatórios que recrutam outras células (também liberadoras de mediadores inflamatórios) e colaboram para o desenvolvimento da fibrose pulmonar. A grande presença de neutrófilos, eosinófilos, linfócitos, mastócitos, monócitos e macrófagos alveolares é uma característica histológica marcante da fase inicial de várias doenças pulmonares fibróticas. Estas células inflamatórias ativadas são fontes de uma grande quantidade de mediadores.

Os macrófagos são células importantes no desenvolvimento da fibrose pulmonar, pois produzem grande quantidade de Interleucina-8 (IL-8), que é um 
importante agente quimiotático para neutrófilos; também produzem PDGF e TGF- $\beta$ (potente agente fibrótico), que induzem fibroblastos e miofibroblastos a produzirem várias proteínas de matriz [15]. A Interleucina-4 (IL-4) também apresenta importante papel na patogênese da fibrose pulmonar, uma vez que ativa as células mononucleares e fibroblastos, estimulando a síntese de colágeno [16].

Um aspecto importante deve ser considerado: nem toda citocina deve ser prófibrótica, pois o Interferon- $\gamma$ (IFN- $\gamma$ ) inibe a síntese de colágeno pelos fibroblastos. Desta forma, sugere-se um balanço entre as citocinas reguladoras positivas e negativas na modulação da resposta fibrótica a uma lesão [12].

3. Eventos fibróticos: O acúmulo de proteínas da MEC é essencial para a cicatrização e, justamente por isso, há um equilíbrio entre formação e degradação da matriz. Em doenças fibróticas, há um desequilíbrio, ocorrendo aumento na produção e diminuição da degradação de proteínas da matriz [1; 2]. Esta degradação ocorre predominantemente pela atividade de enzimas proteolíticas, como as metaloproteases, desintegrinas e mataloproteases de membrana (ADAM), sendo que os inibidores de metaloprotease (TIMP) também são de suma importância no remodelamento da matriz, em decorrência da inibição da atividade das metaloproteinases [17].

No pulmão, o acúmulo excessivo de colágeno intersticial (principalmente do tipo I, III e IV) é responsável pela destruição da arquitetura pulmonar e consequente falha na troca gasosa; vale a pena reforçar a importância das células epiteliais alveolares (pneumócitos) do tipo II neste processo fibrótico, uma vez que estas células são as principais produtoras de fatores fibrogênicos [18; 19]. 


\subsection{Bleomicina}

A Bleomicina é um antibiótico e quimioterápico produzido pela bactéria Streptomyces verticillus [2o]. Inicialmente, a droga se mostrou eficaz em tratamentos de carcinomas de células escamosas sem induzir toxicidade renal. Porém, com o uso desta substância em crescimento, a toxicidade pulmonar da bleomicina ficou evidenciada pela capacidade da droga em induzir fibrose pulmonar acompanhada de metaplasia epitelial [21].

Atualmente, a fibrose pulmonar induzida pela bleomicina em camundongos é o modelo experimental mais comum para estudo da fibrose pulmonar idiopática humana [22]. Para exercer seu efeito citotóxico, a droga circulante deve alcançar e entrar no endotélio pulmonar. A sensibilidade particular deste tecido é provavelmente relacionada com o baixo nível da enzima inativadora da droga [21].

A hidrolase da bleomicina (enzima inativadora da bleomicina) influencia diretamente a ação do fármaco em diferentes tecidos. O pulmão mantém baixos níveis desta enzima, o que o torna um alvo mais suscetível da ação desta substância do que outros tecidos [20].

A pneumonia induzida pela bleomicina é caracterizada por dano no epitélio alveolar e endotelial, metaplasia do epitéleio bronquial, dano a membrana basal e infiltrado de células inflamatórias nos alvéolos e septos alveolares. Estudos em pacientes com FPI demonstraram que o dano pulmonar provocado pela bleomicina pode progredir para um quadro de fibrose pulmonar, quando a alveolite gerada não se resolve adequadamente. Este quadro é basicamente caracterizado pelo acúmulo de fibras de colágeno no parênquima pulmonar [23]. Durante a primeira semana após a administração da droga de forma intratraqueal, o recrutamento de leucócitos e edema pulmonar é observado. No decorrer da segunda semana, pode ser observado respostas fibróticas, como a proliferação de fibroblastos e síntese de componentes da MEC. Vários tipos celulares do sistema imune, incluindo macrófagos e neutrófilos, têm sido indicados com papel essencial no desenvolvimento desta doença [22].

A elevada síntese de citocinas pró inflamatórias [Interleucina-1 (IL-1), Fator de Necrose Tumoral- $\alpha$ (TNF- $\alpha$ ), Interleucina-6 (IL-6) e IFN- $\gamma$ ] é seguida pelo aumento de expressão de marcadores pró-fibróticos (TGF- $\beta$, fibronectina, pró-colágeno 1), com um pico ao redor do $14^{\circ}$ dia. A mudança entre a inflamação e a fibrose parece acontecer por volta do $9^{\circ}$ dia após a administração da bleomicina [20]. 


\subsection{Células NKT}

Por definição, os linfócitos $\mathrm{T}$ incluem todas as células que expressam em sua superfície um receptor antigênico (TCR) associado com as moléculas do complexo CD3 [24]. As células NKT são um subconjunto de linfócitos $\mathrm{T}$ que expressam receptores de superfície característicos das linhagens de células T e NK, incluindo o TCR e o marcador celular NK 1.1 (CD161 em humanos) [25].

Nos vertebrados, as moléculas do MHC de classe I e de classe II capturam os peptídeos derivados de patógenos no retículo endoplasmático ou no compartimento endossômico e os apresentam na superfície celular para reconhecimento de linfócitos $\alpha \beta$ TCR CD8+ ou CD4+, respectivamente. Em contraste, as moléculas CD1, uma família de moléculas semelhantes ao MHC de classe I, apresentam lipídios ao invés de peptídeos para as células T, sendo o CD1d o único isótipo de CD1 que interage com o subconjunto de células restrito a esta molécula, as células NKT [26]. O CD1d é expresso predominantemente por células hematopoiéticas e em células apresentadores de antígenos [25].

As células NKT restritas ao CD1d foram divididas em dois grupos: NKT tipo I e NKT tipo II. As células NKT tipo I também são chamadas de células NKT invariantes (iNKT), por expressarem um TCR invariante codificado pelo segmento do gene Va14Ja18, em camundongos, e Va24Ja18, em humanos, pareado com uma das cadeias $\mathrm{V} \beta(\mathrm{V} \beta 8, \mathrm{~V} \beta 7$ e $\mathrm{V} \beta 2$ em camundongos e $\mathrm{V} \beta 11$ em humanos) [27].

$\mathrm{O}$ entendimento do fenótipo, do desenvolvimento e da modulação deste tipo celular tem sido feito a partir de estudos que usam um antígeno substituto identificado em uma esponja marinha. O glicolipídio a-galactosilceramida ( $\alpha$-GalCer) é um forte ativador das iNKT e reconhecido pelo TCR no contexto das moléculas CD1d [28], resultando em secreção de citocinas, diminuição na expressão do TCR e apoptose [29]. Os invertebrados marinhos são conhecidos por ser um grande reservatório de moléculas bioativas. As esponjas, animais multicelulares mais simples e antigos da Terra, são uma das principais fontes de cerebrosídeos. Estas moléculas pertencem à família dos glicoesfingolipídios, que consiste em uma parte de ceramida conectado a um resíduo polar (monossacarídeo ou polissacarídeo).

$\mathrm{O}$ uso deste glicolipídeo sintético desencadeia uma reação no sistema imunológico após a interação com as células NKT, ativando linfócitos B, linfócitos T e 
macrófagos para atuar contra tumores e infecções (Th1) ou proteção contra doenças autoimunes (Th2) [45].

As células NKT tipo II tem um repertório mais diverso de TCR e são uma população celular menos estudada que as NKT tipo I. No entanto, o papel das NKT tipo II foi descrito em modelo transgênico de infecção viral de Hepatite $\mathrm{B}$, infecção por Trypanosoma cruzi e na colite humana ulcerativa [3o]. A participação das NKT tipo II também é descrita em diversas doenças autoimunes [27]. Mesmo com pouco conhecimento sobre suas funções fisiológicas, a estimulação das NKT tipo II tem sido feita pelo uso de sulfatídeos, que agem seletivamente neste subconjunto de células [30] através da sua forte ligação com as moléculas CD1 em humanos, e CD1d em camundongos [29].

Os sulfatídeos são glicoesfingolipídeos próprios derivados da mielina, descritos como capazes de modular diferentes doenças em camundongos [46]. Esta substância consiste em uma variedade de isoformas existentes com diferentes propriedades físico-químicas. A composição das isoformas difere entre os organismos, onde o sulfatídeo presente na bainha de mielina é predominantemente composto por ácidos graxos de cadeia longa e insaturados ou hidroxilados, enquanto o sulfatídeo proveniente das células $\beta$ do pâncreas contém uma alta proporção de isoformas de ácidos graxos de cadeia curta que não foram hidroxilados. Alguns estudos demonstram que o comprimento da cadeia de ácidos graxos é o que determina a capacidade dessas moléculas estimularem células NKT restritas a CD1d e promover sua função biológica [76].

\subsubsection{FUNÇÕES DAS CÉLULAS NKT NO PULMÃO E NA FIBROSE PULMONAR}

A via aérea é a principal rota de entrada de patógenos no corpo e a habilidade das células NKT em responder rapidamente contra estas infecções demonstra a importâncias destas células na infecção pulmonar aguda, além de evidências também indicarem sua importância na regulação de infecções crônicas e inflamações. Durante a infecção, a resposta imune inata no pulmão tem que ser induzida rapidamente, mas a inflamação tem que ser balanceada para evitar lesões nas estruturas da via aérea [31]. 
Estas células agem como uma ponte entre a resposta imune inata e resposta imune adaptativa e podem apresentar propriedades pró e anti-inflamatórias dependendo do seu modo de ativação, ambiente de citocinas, força e duração de ativação, assim como outros parâmetros [25]. Portanto, a dimensão da ativação dessas células no pulmão depende do balanço de citocinas pró-inflamatórias e fatores reguladores. Em inflamações persistentes, pode haver desregulação na cicatrização, desencadeando acúmulo de proteínas da MEC e consequente perda da função das vias aéreas [31].

A ação das células NKT e a habilidade de secretar altas quantidades de citocinas têm demonstrado que esta população tem um importante papel na iniciação da resposta imune protetora [32], formando sinapses com diferentes tipos celulares que integram sinais inibitórios e ativadores, além de representarem uma importante fonte de citocinas, particularmente o IFN- $\gamma$ [31]. De forma curiosa, as células iNKT são capazes de produzir uma grande quantidade de citocinas, incluindo IL-2, IL-4, IL-6, IL-10, IL-13, TGF- $\beta$, IFN- $\gamma$ e TNF- $\alpha$ que, quando secretadas, podem ativar rapidamente uma variedade de outros tipos celulares, como células dendríticas, macrófagos, células B e células T convencionais, além de outros tipos de células NKT [33].

Este grupo celular também pode mediar um efeito protetor contra a fibrose. As células NKT são capazes de produzir IFN- $\gamma$, que, por ser uma citocina de padrão Th1, desempenha um papel crítico na polarização da resposta imune contra a lesão ao invés da fibrose progressiva e suprime a atividade de proliferação dos fibroblastos e produção de colágeno. Em modelos de fibrose pulmonar induzida por bleomicina, a ausência do recrutamento de células NKT resultou na falta de IFN- $\gamma$ e exacerbou a fibrose. O tratamento com IFN- $\gamma$ promoveu efeito terapêutico, demonstrando a importância desta citocinas liberada pelas células NKT na regulação da fibrose pulmonar [34; 35]. Pacientes portadores da FPI tratados com IFN- $\gamma$ apresentaram mudanças na expressão de biomarcadores da fibrose, imunomodulação e atividade antimicrobiana. Estes resultados reforçam a ideia de que o IFN- $\gamma$ atua na FPI por diferentes vias [34]. Assim sendo, as NKT tem função vital exercendo imunoregulação devido a sua liberação rápida e massiva de citocinas de padrão tipo Th1 e Th2, especialmente o IFN- $\gamma$ e a IL-4 [24].

Como estas células podem direcionar a atividade dos macrófagos para M1 ou M2 e influenciar diretamente o desenvolvimento da fibrose, acreditamos que o 
melhor entendimento e caracterização dos fenótipos das NKT, assim como das citocinas produzidas (Th1/Th2) e a consequente modulação da doença a níveis celulares e moleculares, possa ser mais uma ferramenta para uma abordagem terapêutica, visando o tratamento dessa doença.

\subsection{Macrófagos}

Os macrófagos compreendem uma população heterogênea de células que pertencem ao sistema de fagócitos mononucleares [36]. Macrófagos residentes e infiltrados realizam um vasto repertório de funções na saúde com lesões e infecções. Entre outras funções, os macrófagos executam a fagocitose e destroem uma diversa gama de micro organismos infecciosos, além de também fagocitar detritos de tecidos, de células do parênquima e de neutrófilos que sofreram apoptose.

Estas células orquestram o reparo de tecidos danificados e servem como uma ponte entre o sistema imune inato e adaptativo, além de serem importantes imunorreguladores e atuarem na homeostase dos tecidos. Populações de macrófagos podem ser distintas funcionalmente e, juntamente com as células dendríticas de um mesmo tecido, atuam em papéis críticos, como em iniciação e reparação de cicatrizes. De acordo com todas estas atividades, os macrófagos adquirem diferentes fenótipos, ditados pela forma, estágio e local de ativação [36; 37 .

Os macrófagos alveolares e intersticiais representam as duas maiores populações deste tipo celular, que ocupam diferentes compartimentos no pulmão, servindo e agindo como importantes sentinelas no reconhecimento de patógenos invasores e células apoptóticas. Esses se originam dos monócitos circulantes nos vasos sanguíneos e povoam os tecidos sob estado de inflamação [38].

\subsubsection{SUBPOPULAÇÕES DE MACRÓFAGOS}

A polarização de macrófagos foi dividida entre dois diferentes fenótipos [37] que apresentam padrões de ativações diferentes após exposição de citocinas e/ou agonistas do receptor Toll-like. Ao menos dois subconjuntos de macrófagos funcionais foram extensivamente estudados [38]: os macrófagos M1 e M2, ativados pela via clássica e pela via alternativa, respectivamente. Este nome foi dado por analogia ao padrão de citocinas Th1/Th2 secretadas por linfócitos T CD4+ auxiliares, 
que interagem com os macrófagos [39] e direcionam para o perfil M1 ou M2 no micro ambiente onde esta população celular se encontra [40].

A “ativação clássica” de macrófagos (M1) tem perfil pró-inflamatório e é dependente de moléculas secretadas por linfócitos T CD4+ auxiliares ativados, de padrão Th1 ou de células Natural Killers (NK), em particular o IFN- $\gamma$, além de outros agentes pró-inflamatórios, como o TNF-a e o lipopolissacarídeo bacteriano (LPS). A ativação clássica resulta em uma população de macrófagos com aumento na sua capacidade microbicida e aumento na secreção de citocinas pró-inflamatórias [39] como TNF-a, IL-1, IL-12, IL-8 e IL-6 [40] e, com o aumento também nos níveis de produção de óxido nítrico (NO), apresentando um importante papel na proteção contra patógenos intracelulares [38].

Em contraste, citocinas como a IL-4 e IL-13, que são pertencentes ao grupo de linfócitos T CD4+ auxiliares de padrão Th2, são indutores da via de "ativação alternativa" dos macrófagos [39] e tem um papel importante na alergia, infecções parasitárias e envolvimento no controle de reparo tecidual [40]. Este grupo, também chamado de M2, tem um perfil anti-inflamatório e exibe hiporeatividade aos ligantes de M1, como o LPS. Os macrófagos se convertem para o fenótipo de M2 nos estágios finais de uma resposta de M1. Como resultado, os macrófagos inicialmente diminuem sua atividade pró-inflamatória e mudam sua função em direção a resolução local da inflamação e do reparo tecidual [37]. A iniciação da via alternativa pelas citocinas de padrão Th2 induz a ativação do gene de transdução de final e ativador da transcrição6 (STAT6), que leva à produção de fatores pró-fibróticos [38].

Os macrófagos tem um perfil caracterizado pela sua plasticidade, no qual a sua expressão gênica pode ser influenciada pelo tipo, concentração e longevidade de agentes estimulantes, como as citocinas de padrão Th1 e Th2. Ao contrário de induzir uma diferenciação estável em subconjuntos distintos de macrófagos, esses agentes estimulantes geram um padrão funcional transitório que volta ao seu estado basal após 3-7 dias. Esta plasticidade representa uma resposta adaptativa a estímulos diferentes em micro ambientes, onde os macrófagos migram em resposta a sinais quimiotáticos ou quimiocinas, fagocitam células mortas ou detritos e interagem com subconjuntos diferentes de células T [39].

Em casos de fibrose pulmonar em humanos e em modelos experimentais em animais, foi observado que o aumento da síntese de tecido conjuntivo é quase sempre precedido pela intensificação no influxo de células inflamatórias 
ativadas. Destas células, os macrófagos alveolares foram as células mais proeminente no espaço alveolar, compreendendo mais de $95 \%$ do total de células [41].

Estudos sugerem que há evidências suficientes para afirmar que macrófagos alveolares possuem um papel na inflamação pulmonar e fibrose. Além do número de macrófagos aumentarem no local, foi demonstrado que este tipo celular é capaz de produzir diversas citocinas capazes de regular leucócitos e fibroblastos, como IL-1, PDGF, TNF- $\alpha$, TGF- $\beta$, e proteínas, como a fibronectina [41].

O TGF- $\beta$, em especial, é uma citocina chave na formação da fibrose [42], tendo papel essencial na regulação do processo fibrótico, modulando o fenótipo de fibroblastos e regulando o metabolismo da matriz [43]. É um dos mais potentes reguladores da inflamação e da síntese de tecido conjuntivo in vitro e in vivo [41]. Em modelos de fibrose pulmonar, níveis elevados na expressão do gene do TGF- $\beta$ precederam as perturbações na expressão dos genes das proteínas da matriz extracelular [42].

A persistência de macrófagos do tipo M2 em tecidos tem sido ligada à fibrose clínica e experimental. O macrófago M2 tem um aumento de expressão da molécula FIZZ1, que está relacionada à ativação de fibroblastos e sua diferenciação em miofibroblastos. As funções do M2 são dependentes da via da arginase-1 que leva ao crescimento celular, a deposição de colágeno e à síntese de MEC [44].

É relatado também que macrófagos de pacientes com fibrose respondem especificamente às citocinas IL-4 e IL-10, ativando a sinalização intracelular para a transcrição dos genes STAT6 e STAT3, respectivamente. Este resultado suporta a sugestão na qual a indução e manutenção do fenótipo M2 de macrófagos alveolares é uma característica específica da fibrose pulmonar e destaca também, a importância do papel do macrófago alveolar polarizado para o fenótipo M2 na patogênese deste tipo de fibrose [40]. 


\section{HIPÓTESE}

Neste contexto, foi formulada a hipótese de que as células NKT influenciariam o desenvolvimento da fibrose pulmonar induzida pela bleomicina via modulação de subpopulações de macrófagos, em especial, os macrófagos M2. 


\section{OBJETIVO}

Comparar o desenvolvimento da fibrose pulmonar induzida pela bleomicina em camundongos selvagens e knockouts para células NKT, na presença ou não de ativadores para este grupo celular e, entender os mecanismos celulares e moleculares envolvidos neste cenário.

\subsection{Estratégia Experimental}

Inicialmente, o modelo animal foi estabelecido. A avaliação do lavado broncoalveolar (BAL), da síntese de hidroxiprolina e deposição de colágeno foram os parâmetros utilizados para avaliar a dose e tempo utilizados no protocolo que, finalmente, foi escolhido como $5 \mathrm{mg} / \mathrm{kg}$ e 14 dias de intervalo para ação da droga.

Camundongos Ja18 ${ }^{-/-}$foram utilizados para avaliar o papel das células NKT no desenvolvimento da doença. O BAL, assim como a síntese de hidroxiprolina e a deposição de colágeno, foram avaliados. Os transcritos gênicos (mRNA) foram quantificados por RT-PCR e quantificados por Bioplex. A participação celular foi analisada por citometria de fluxo. Todas as análises convergem para a necessidade de avaliar a expressão de fatores inflamatórios e anti-inflamatórios (TNF- $\alpha$, IL-6, IL-10 e FoxP3), pró-fibróticos (TGF- $\beta$ e Vimentina) e o balanço Th1/Th2, assim como o infiltrado celular e a produção de citocinas por células T CD4+ e NKT.

A participação dos macrófagos foi analisada indiretamente pela quantificação de transcritos gênicos (mRNA) por RT-PCR para detecção de recrutamento macrofágico (MCP-1), marcadores de M1 (iNOS, IRF5), marcadores de M2 (arginase-1, IRF4), assim como a análise celular por citometria de fluxo para a detecção do infiltrado celular através da marcação de células CD11b+F4/80+CD86+ (M1) e CD11b+F4/80+CD206+ (M2). 


\section{MATERIAIS E MÉTODOS}

\subsection{Animais}

Foram utilizados camundongos machos $\mathrm{C} 57 \mathrm{Bl} / 6$ e camundongos knockout para células NKT invariantes ( $\mathrm{Ja18}^{-/}$), com 8 a 12 semanas de idade, provenientes do biotério de camundongos isogênicos do Instituto de Ciências Biomédicas da Universidade de São Paulo ou fornecidos pelo Centro de Desenvolvimento de Modelos Experimentais para Medicina e Biologia - CEDEME da UNIFESP. Os protocolos experimentais utilizados foram submetidos à Comissão de Ética em Experimentação Animal (CEEA), ICB/USP e estão de acordo com os princípios éticos na experimentação animal adotado pelo Colégio Brasileiro de Experimentação Animal (COBEA). Os grupos estudados foram: SHAM/Controle, WT BLM (selvagens estimulados com bleomicina i.t.), Ja18\%- BLM (animais knockouts estimulados com bleomicina i.t.), BLM + aGalCer e BLM + Sulfatídeo (camundongos selvagens estimulados com bleomicina e ativadores de células NKT tipo I e tipo II, respectivamente).

\subsection{Protocolo de indução de fibrose pulmonar}

Os animais foram anestesiados com cetamina/xilasina e receberam $5 \mathrm{mg} / \mathrm{kg}$ de sulfato de bleomicina (1.5-2.o unidades/mg, Sigma-Aldrich, St. Louis, Missouri, EUA) $(40 \mu \mathrm{l})$ diluída em $\mathrm{NaCl} 0.9 \%$ por via intratraqueal. Os animais controles receberam apenas salina. Após 14 dias, os animais foram eutanasiados para coleta de tecido.

\subsection{Administração de a-Galactosilceramida e Sulfatídeo}

Para a ativação das células NKT, foi utilizado o $\alpha$-GalCer (KRN70oo - 1mg Alexis Biochemicals/Alexis Corporation, Lausen, Suiça, armazenamento a $-20{ }^{\circ} \mathrm{C}$ ) e o sulfatídeo (sulfatídeos obtidos de cérebro bovino - $5 \mathrm{mg}$ Sigma-Aldrich, armazenamento a $-20^{\circ} \mathrm{C}$ ).

A $\alpha$-GalCer foi diluída e uma solução clorofórmio:metal (2:1) e aliquotada em tubos de vidro contendo $5^{0} \mu \mathrm{g}$ da substância. No dia do uso, cada amostra foi 
ressuspendida em $2 \mathrm{~mL}$ de solução de PBS $1 \mathrm{x}+$ Tween20 0,5 \% e colocada no sonicador por 90 minutos a $60{ }^{\circ} \mathrm{C}$. Foi injetado $200 \mu \mathrm{l}$ (i.p.) (5 $\mu \mathrm{g}$ de $\alpha$-GalCer) em cada animal no dia do início da administração da bleomicina.

O sulfatídeo foi diluído em solução metanol:clorofórmio:água (1:2:0,1) e aliquotado em tubos de vidro contendo $200 \mu \mathrm{g}$ da substância. No dia do uso, cada amostra foi ressuspendida em $2 \mathrm{~mL}$ de solução de PBS 1x + Tween20 0,5 \% e colocada no sonicador por 60 minutos a $60{ }^{\circ} \mathrm{C}$. Após esse processo, foi injetado 200 $\mu \mathrm{L}$ (i.p.) (20 $\mu \mathrm{g}$ de sulfatídeo) em cada animal no dia do início da administração da bleomicina (Esquema 1).

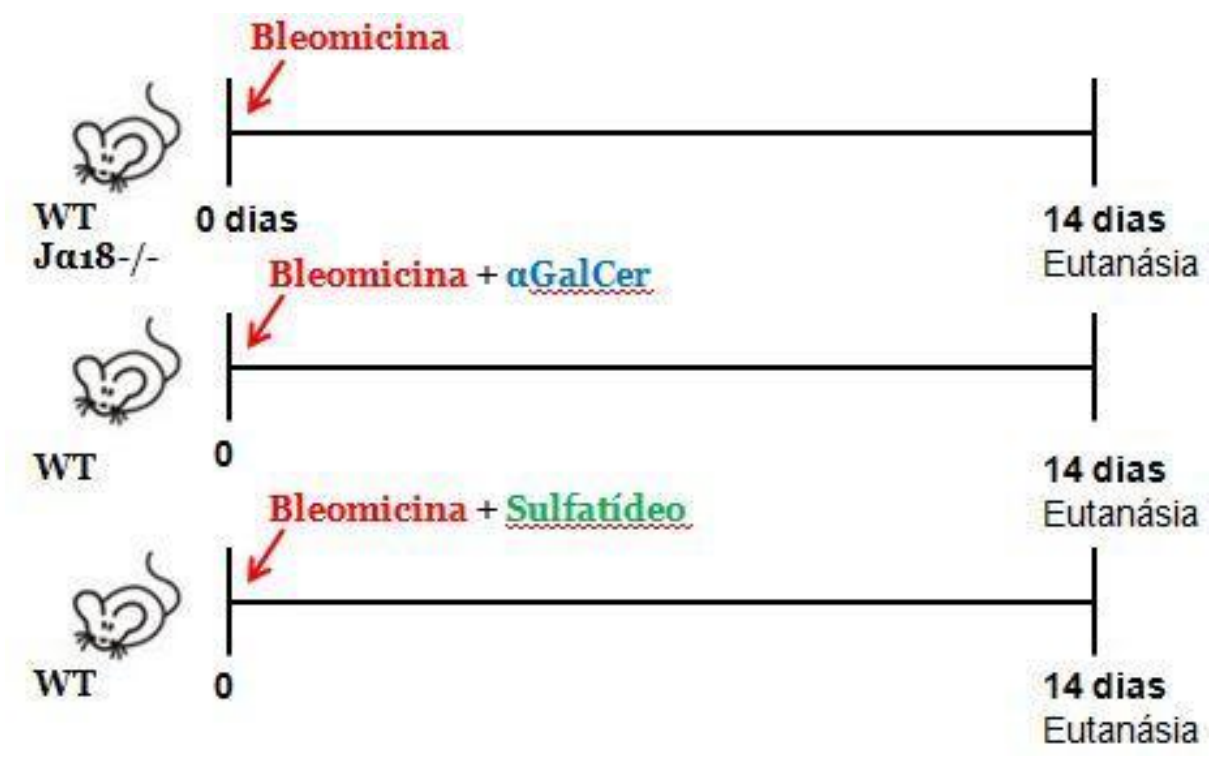

Esquema 1. Representação esquemática do processo de indução de fibrose pulmonar. Bleomicina com ou sem ativadores das células NKT foram administrados no dia zero (i.t. e i.p., respectivamente). A análise dos dados conta com aspiração do lavado broncoalveolar (BAL), soro, separação dos lobos pulmonares para análise histológica de transcritos gênicos e para análise por citometria de fluxo. $\mathrm{n}=5$ por grupo.

\subsection{Obtenção do Lavado Broncoalveolar (BAL)}

Os animais eutanasiados com excesso de anestésico (14 dias após a indução da fibrose com a bleomicina) tiveram a traqueia canulada e o BAL coletado, injetando-se $1 \mathrm{~mL}$ de PBS (solução tampão) e aspirando-se em seguida. Este procedimento foi realizado 2 vezes. 


\subsection{Contagem total e diferencial do BAL}

$\mathrm{O}$ BAL foi centrifugado ( $170 \mathrm{Xg}$, por 10 minutos, a $4{ }^{\circ} \mathrm{C}$ ), o sobrenadante removido e o botão celular foi ressuspendido em $1 \mathrm{~mL}$ de PBS. Um volume de uma solução contendo 0,5 \% de cristal violeta dissolvido em $30 \%$ de ácido acético foi adicionado a 9 volumes de suspensão celular. O número total de células foi determinado por contagem em uma câmara de Neubauer. A contagem diferencial de células foi feita pelo método de centrifugação em Cytospin coradas com hematoxilina-eosina para posterior análise em microscópio.

\subsection{Quantificação de hidroxiprolina}

Para a quantificação do aminoácido, os pulmões foram descongelados e liofilizados. Uma solução de hidróxido de sódio na concentração de $2 \mathrm{~N}$ e 3,3 $\mathrm{N}$ foi adicionada às amostras e aos pontos da curva feita pela diluição seriada do padrão de hidroxiprolina, respectivamente. As amostras foram autoclavadas a $120{ }^{\circ} \mathrm{C}$ por 20 minutos e acrescidas de $450 \mu \mathrm{L}$ de cloramina T. Em seguida, foi adicionado 500 $\mu \mathrm{L}$ do reagente de Ehrlich para a formação do cromóforo. As amostras foram analisadas por espectrofotometria no comprimento de onda de $500 \mathrm{~nm}$ e a concentração de hidroxiprolina quantificada proporcionalmente ao peso da amostra.

\subsection{Análise histopatológica}

Os pulmões foram retirados e fixados em solução de formalina (10 \%) tamponada com PBS por 24 hs, e depois mantidos em álcool 70 \% para fixação. Após a fixação, os fragmentos foram incluídos em parafina, cortados e corados pelo método de picrosirius para quantificação de colágeno.

\subsection{Imunohistoquímica (IHQ)}

O tecido extraído foi fixado e colocado em lâminas desparafinizadas para o começo do protocolo. A recuperação antigência foi feita utilizando o tampão Tris/EDTA ph 9,0 para, posteriormente, ser realizado o bloqueio da peroxidase endógena com peróxido de hidrogênio a $3 \%$. Um bloqueador de proteínas foi 
utilizado para bloqueio de ligações inespecíficas, sendo incubado nesta solução por 30 min. O anticorpo primário foi utilizado na diluição de 1:50, permanecendo incubado a temperatura ambiente por uma hora. A visualização foi feita utilizando o Kit Envision+/HRP Dual Link (Cod. K4061, Dako, Glostrup, Dinamarca), juntamente com o substrato $\mathrm{DAB}$, fornecendo o cromóforo para a revelação. A contra coloração foi feita com hematoxilina e as lâminas analisadas em microscópio de luz, onde foram escolhidos dez campos aleatórios. A quantificação foi feita baseada no número de marcações positivas por campo.

\subsection{Extração do RNA total e análise de transcritos gênicos}

O RNA total foi isolado usando o método de TRIzol (Invitrogen, Carlsbad, California, EUA) e a concentração de RNA foi determinada pela leitura de absorbâncias de 260nm pelo nanodrop (ND10o Thermo Scientific, Delaware, EUA). O cDNA foi sintetizado pela transcriptase reversa MML-V (Promega, Wisconsin, EUA). O RT-PCR foi realizado usando o ensaio de PCR quantitativo com sonda Taqman (Applied Biosystem, Massachusetts, EUA). A sequência dos primers foi desenhada de acordo com a sequência de RNA publicada no genebank. As condições de termociclamento foram determinadas para cada primer. A análise dos resultados foi feita pelo programa Sequence Detection Software 1.9 (SDS) e a expressão do mRNA de cada molécula foi normalizada pela abundância do gene HPRT (housekeeping gene); subsequentemente, todos os resultados foram expressos em unidades arbitrárias em n-vezes diferente em relação ao respectivo grupo controle. A expressão relativa foi calculada através da fórmula $2^{\wedge}-\Delta \Delta \mathrm{Ct}$.

Foram analisados transcritos gênicos para TGF- $\beta$, IL-4, Vimentina, IFN- $\gamma$, TNF- $\alpha$, IL-10, FoxP3, assim como fatores de transcrição e produtos de macrófagos, como MCP-1, IRF4, IRF5, iNOS e Arginase-1, todos provenientes de tecido pulmonar. A quantificação de células NKT também foi feita através do primer para a região Va14Ja18. 


\subsection{Quantificação proteica por BioPlex}

Os níveis de citocinas foram medidos e analisados através do sistema BioPlex. Foi utilizado o mouse base kit da Bio-Rad (Bio-Rad, Hercules, CA, EUA), analisando IL-4, IL-5, IL-6, IL-13, TNF- $\alpha$ e IFN- $\gamma$. O ensaio foi desenvolvido de acordo com o protocolo do fabricante. Brevemente, $50 \mu \mathrm{l}$ do homogeneizado do tecido pulmonar, extraído com RIPA e $50 \mu \mathrm{l}$ de citocina recombinante como curva do padrão diluída previamente conforme instruções do manual foram distribuídas em placa com 96 poços na presença de filtros. Em seguida foram adicionadas as esferas conjugadas com os anticorpos anti-citocinas. Após três horas de incubação em temperatura ambiente ou durante a noite sob agitação em geladeira, a placa foi novamente lavada com "Wash Buffer", sendo então, adicionado a cada poço o anticorpo biotinilado de detecção para cada citocina, formando um sanduiche de anticorpos. Após incubação por uma hora, a placa foi novamente lavada e então, foram acrescentados $50 \mu \mathrm{l}$ de Streptavidina conjugada com PE (Bio-Rad), que se liga ao anticorpo biotinilado. Seguiu-se incubação por 30 minutos. Novas lavagens foram realizadas com tampão específico. A leitura foi realizada no Luminex 200, e os dados foram analisados utilizando Bioplex software Manager 6.o.

\subsection{Análise de infiltrado celular por citometria de fluxo}

Os pulmões foram perfundidos e colocados em solução de colagenase IV (Sigma-Aldrich) (1 mg/mL) por 1 hora, a $37^{\circ} \mathrm{C}$. Em seguida, o tecido foi homogeneizado e filtrado. Após a centrifugação (1300 rpm, $10 \mathrm{~min}, 4^{\circ} \mathrm{C}$ ), o botão celular foi ressuspendido em meio de cultura; as células foram, então, submetidas à marcação com anticorpos.

Para marcação de macrófagos, foi utilizado anticorpos anti-CD11b e antiF4/80. A identificação fenotípica da população foi feita pela marcação com anticorpos anti-CD86, para população M1, e anti-CD206, para população M2.

A marcação de linfócitos $\mathrm{T} \mathrm{CD}_{4}+$ e FoxP3+ foi feita através do uso dos anticorpos anti-TCR $\beta$, anti-CD4 e anti-FoxP3. A marcação de células NKT foi feita utilizando anticorpos anti-TCR $\beta$, anti-NK1.1 juntamente com a utilização do tetrâmero de mCD1d conjugado com PBS57 e seus respectivos controles não 
conjugados, fornecidos pelo NIH Tetramer Core Facility da Emory University, Atlanta, EUA. A marcação intracelular para IL-4 e IFN- $\gamma$ também foi feita.

Os anticorpos foram adicionados às células e incubados por 20 minutos a 4 ${ }^{\circ} \mathrm{C}$. As células foram lavadas com PBS contendo 0,01\% de azida sódica e $2 \%$ de soro fetal bovino (tampão FACS) e, posteriormente, transferidas para tubos de leitura de FACS. A leitura foi feita com o aparelho FACS Canto II da empresa BD.

\subsection{Análise dos resultados}

Os resultados foram expressos como média \pm erro padrão da média (EPM) e avaliados utilizando o programa GraphPad 5.0 com análise de variância (ANOVA), seguido do teste Bonferroni para comparações múltiplas ou teste "t" Student, quando apropriado. $\mathrm{O}$ valor de $\mathrm{P}<0,05$ foi utilizado como nível de significância.

Quando os grupos controles de linhagem selvagem e knockout não demonstrarem diferença entre si, a referência utilizada para análise estatística será o controle da linhagem selvagem. 


\section{RESULTADOS}

\subsection{Padronização do modelo animal}

Para validar o protocolo de indução de fibrose pulmonar pela bleomicina, duas concentrações diferentes da droga foram testadas (2 mg/kg e $5 \mathrm{mg} / \mathrm{kg}$ ) em diferentes intervalos de tempo. Através deste procedimento, o experimento serviu como ferramenta para determinar qual dose e intervalo de tempo deveriam ser considerados para criar o melhor modelo animal que mimetizasse a doença da FPI.

A administração da bleomicina pela via intratraqueal levou a um aumento do infiltrado celular nos pulmões avaliados pelo lavado broncoalveolar. Foi observado que o grupo que recebeu a dose de $5 \mathrm{mg} / \mathrm{kg}$ com intervalo de tempo de 7 e 14 dias depois da instilação da droga tiveram níveis aumentados em relação ao controle (Figura 1A). Esta mesma dose levou a um maior desenvolvimento da fibrose, sendo refletida pelo aumento substancial da síntese de hidroxiprolina (Figura 1B) e deposição de colágeno no grupo de 14 dias, análise feita através de cortes histológicos (Figura 1C e Figura 2). 

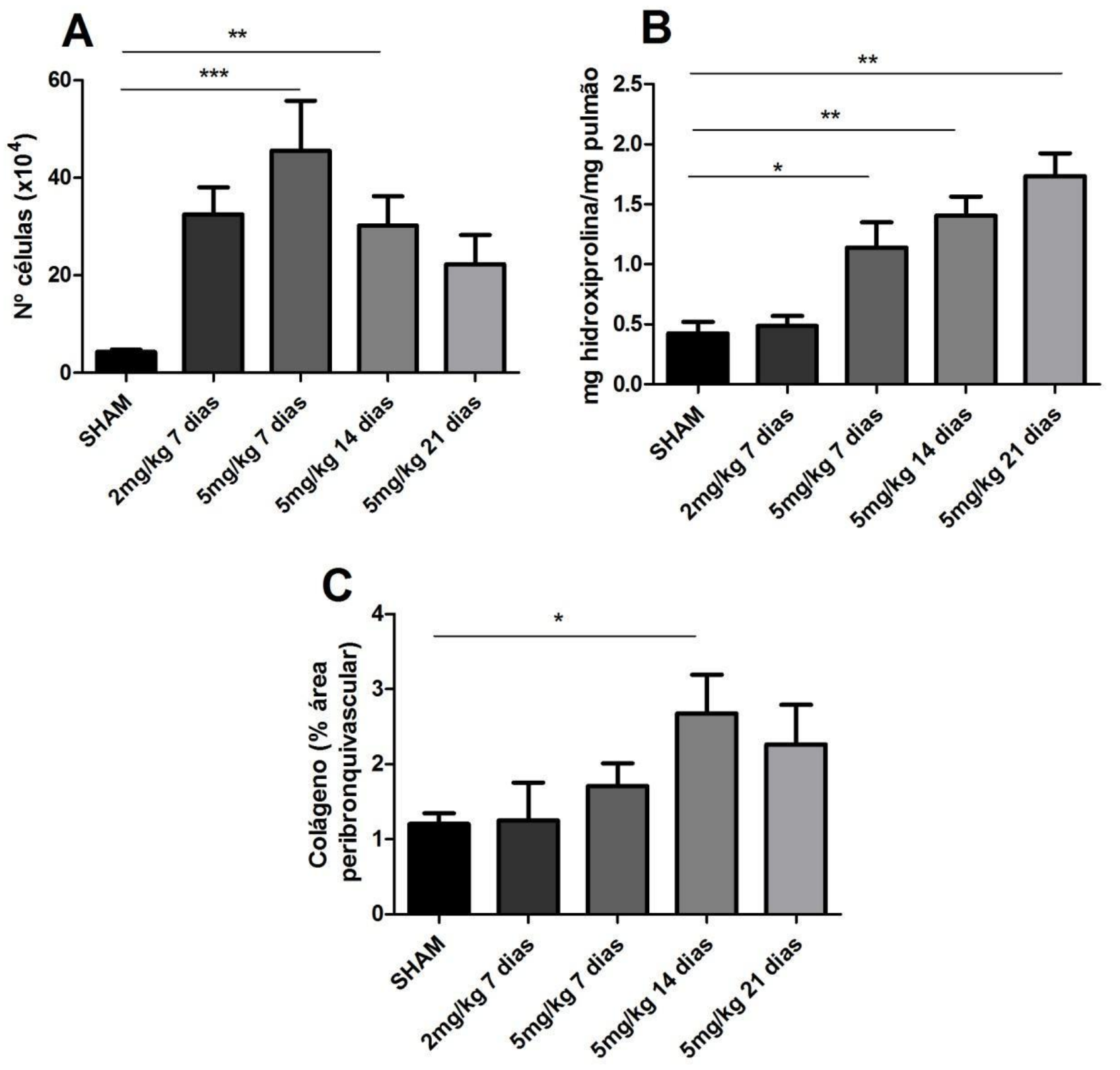

Figura 1. Análise do desenvolvimento da fibrose pulmonar em resposta à instilação intratraqueal da bleomicina. Animais $\mathrm{C} 57 \mathrm{Bl} / 6$ receberam 2 ou $5 \mathrm{mg} / \mathrm{kg}$ de bleomicina e tiveram o infiltrado celular avaliado por (A) BAL; (B) síntese de hidroxiprolina e (C) deposição de colágeno. ${ }^{* * *} \mathrm{p} \leq 0.0001 ;{ }^{* *} \mathrm{p} \leq 0.001 ;{ }^{*} \mathrm{p} \leq 0.05 . \mathrm{n}=5$ por grupo. 

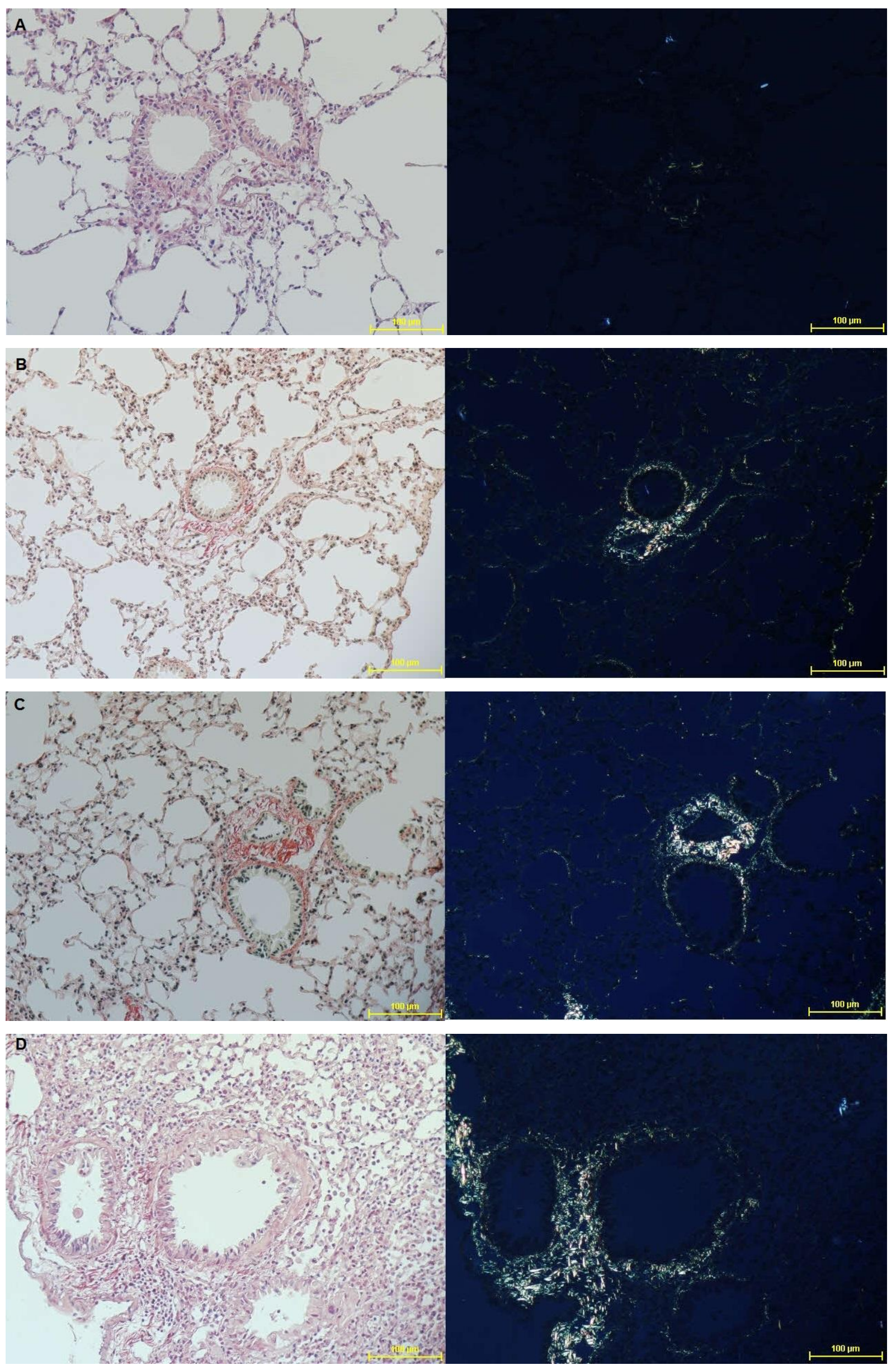


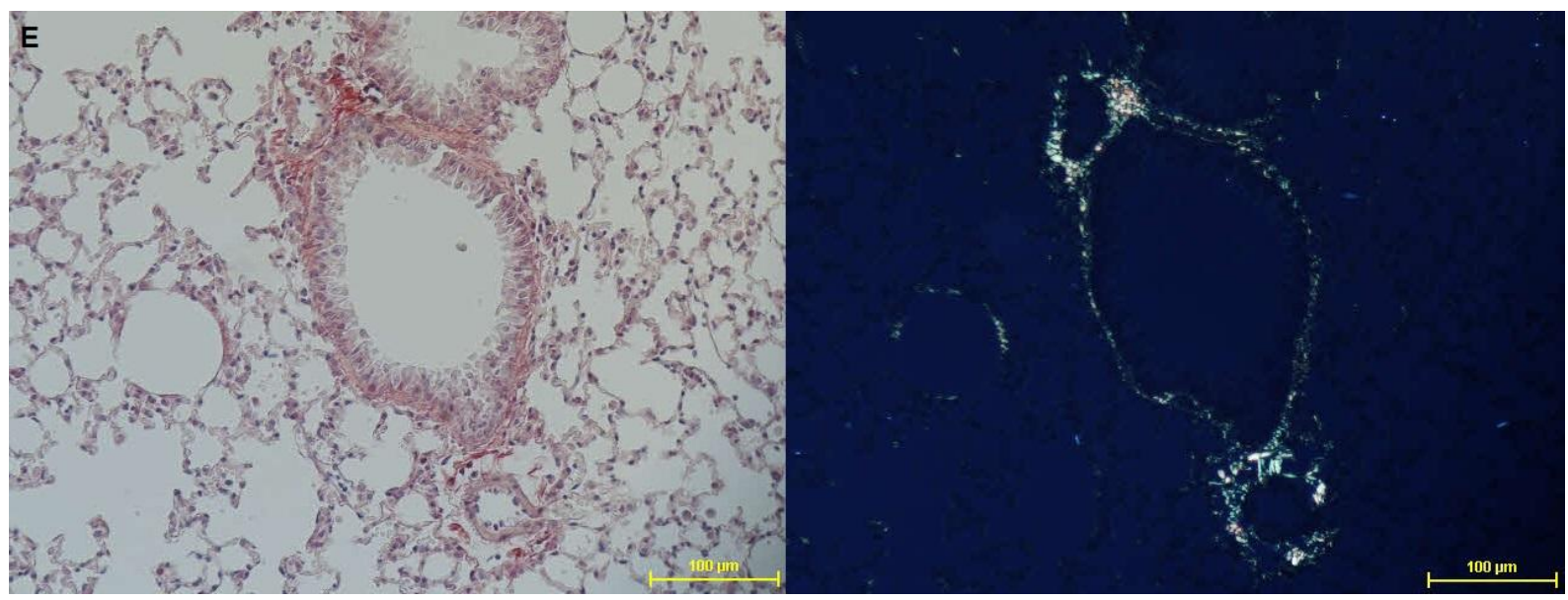

Figura 2. Análise histológica da deposição de colágeno no tecido pulmonar. Os camundongos estimulados com bleomicina ou não, tiveram seus pulmões retirados após 7, 14 ou 21 dias e foram analisados através do método de Picrosirius. Fotos demonstram cortes histológicos do grupo (A) sham; (B) $2 \mathrm{mg} / \mathrm{kg} 7$ dias; (C) $5 \mathrm{mg} / \mathrm{kg} 7$ dias; (D) $5 \mathrm{mg} / \mathrm{kg} 14$ dias e (E) $5 \mathrm{mg} / \mathrm{kg} 21$ dias. Aumento de 20x.

\subsection{Análise de parâmetros fibróticos nos grupos experimentais}

Após ter um modelo animal com indução de fibrose estabelecido de forma consistente, o próximo passo foi avaliar o papel das células NKT no desenvolvimento da doença. Os resultados demonstram que animais Ja18\%- são protegidos contra a lesão da bleomicina, apesar de não ter sido detectada diferença do infiltrado celular no BAL entre os camundongos knockout e selvagens (Figura 3A).

A contagem diferencial de células do BAL foi feita com o intuito de verificar as diferentes populações de linhagem linfóide e/ou mielóide presentes no órgão alvo. Após o tratamento com a bleomicina ou com os ativadores das NKT, as diferentes populações celulares analisadas mantiveram as proporções, seguindo o padrão do grupo controle. A maioria das células detectadas eram macrófagos (cerca de 80\%), seguido pelos linfócitos (cerca de 20\%) e Neutrófilos, que tiveram uma baixa contagem, se não nula (Figura 5).

A infiltração de células NKT no tecido pulmonar não pode ser detectada pelo método de microscopia; portanto, a estratégia escolhida para identificar a presença deste grupo de células específicas foi baseada na amplificação do primer relativo ao TCR invariante presente neste grupo. Os resultados demonstram que o grupo tratado apenas com bleomicina teve uma diminuição da infiltração destas células no órgão alvo (Figura 6). 
No entanto, quando utilizamos a a-galactosilceramida, o agonista de células NKT tipo I, a amplificação do primer Va14Ja18 se eleva novamente, voltando ao seu estado basal (Figura 6).

A síntese de hidroxiprolina no grupo Ja18\%- e nos grupos tratados com agonistas para NKT foi significantemente menor que do grupo selvagem (Figura 3B). O uso da a-galactosilceramida assim como o sulfatídeo, atenuou o processo fibrótico, diminuindo a síntese de hidroxiprolina e deposição de colágeno nos camundongos selvagens (Figura 3B, 3C e Figura 4). 

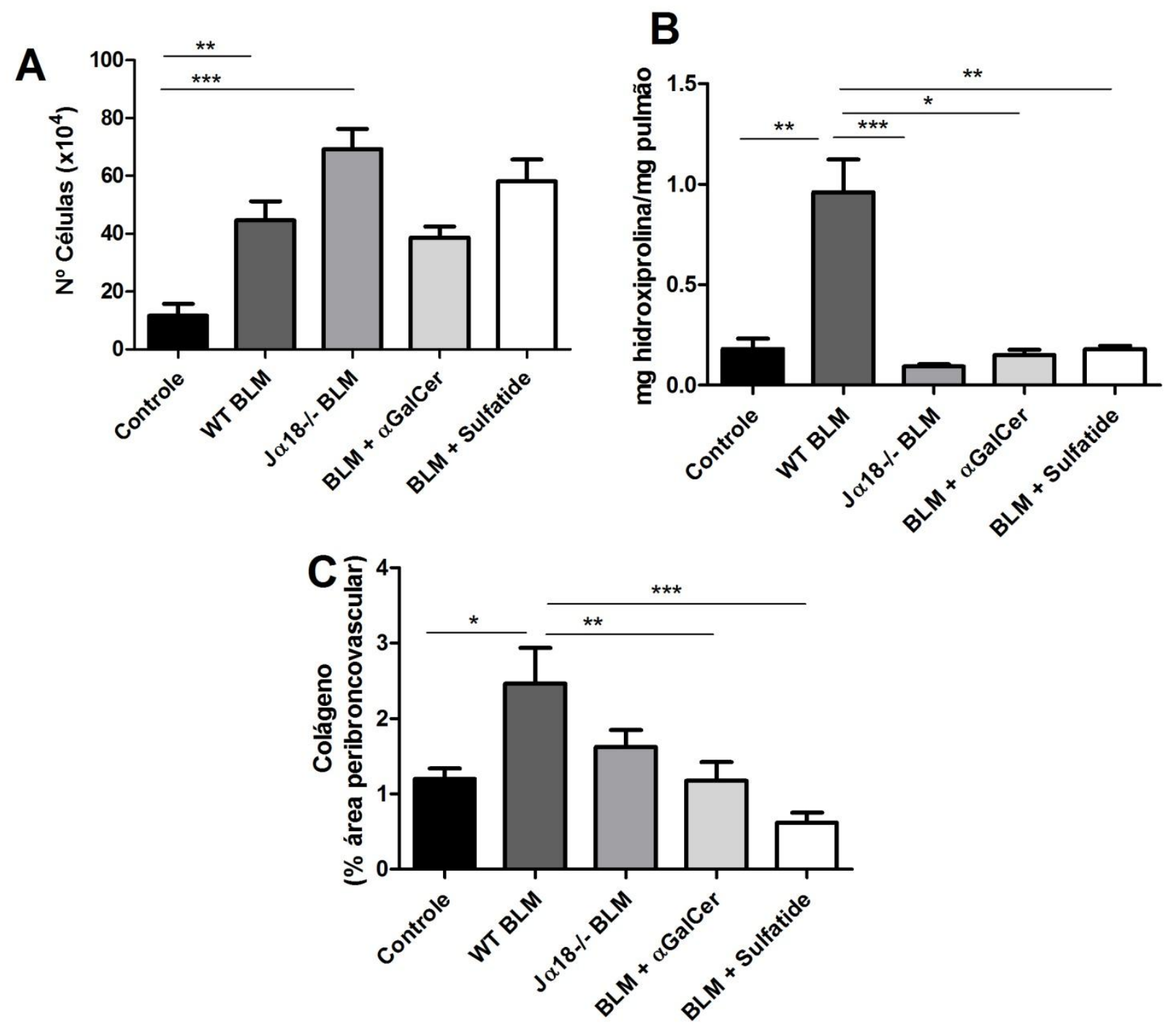

Figura 3. Análise do desenvolvimento da fibrose pulmonar induzida pela bleomicina em camundongos WT e Ja18-/-. Após passarem pelo protocolo de indução de fibrose pulmonar pela bleomicina ( $5 \mathrm{mg} / \mathrm{kg}$ durante 14 dias) na presença ou não de agonistas para células NKT tipo I e tipo II, os camundongos selvagens e knockout tiveram o (A) BAL; (B) síntese de hidroxiprolina e (C) deposição de colágeno avaliados. ${ }^{* * *} \mathrm{p} \leq 0.0001 ;{ }^{* *} \mathrm{p} \leq 0.001 ;{ }^{*} \mathrm{p} \leq 0.05 . \mathrm{n}=5$ por grupo. 

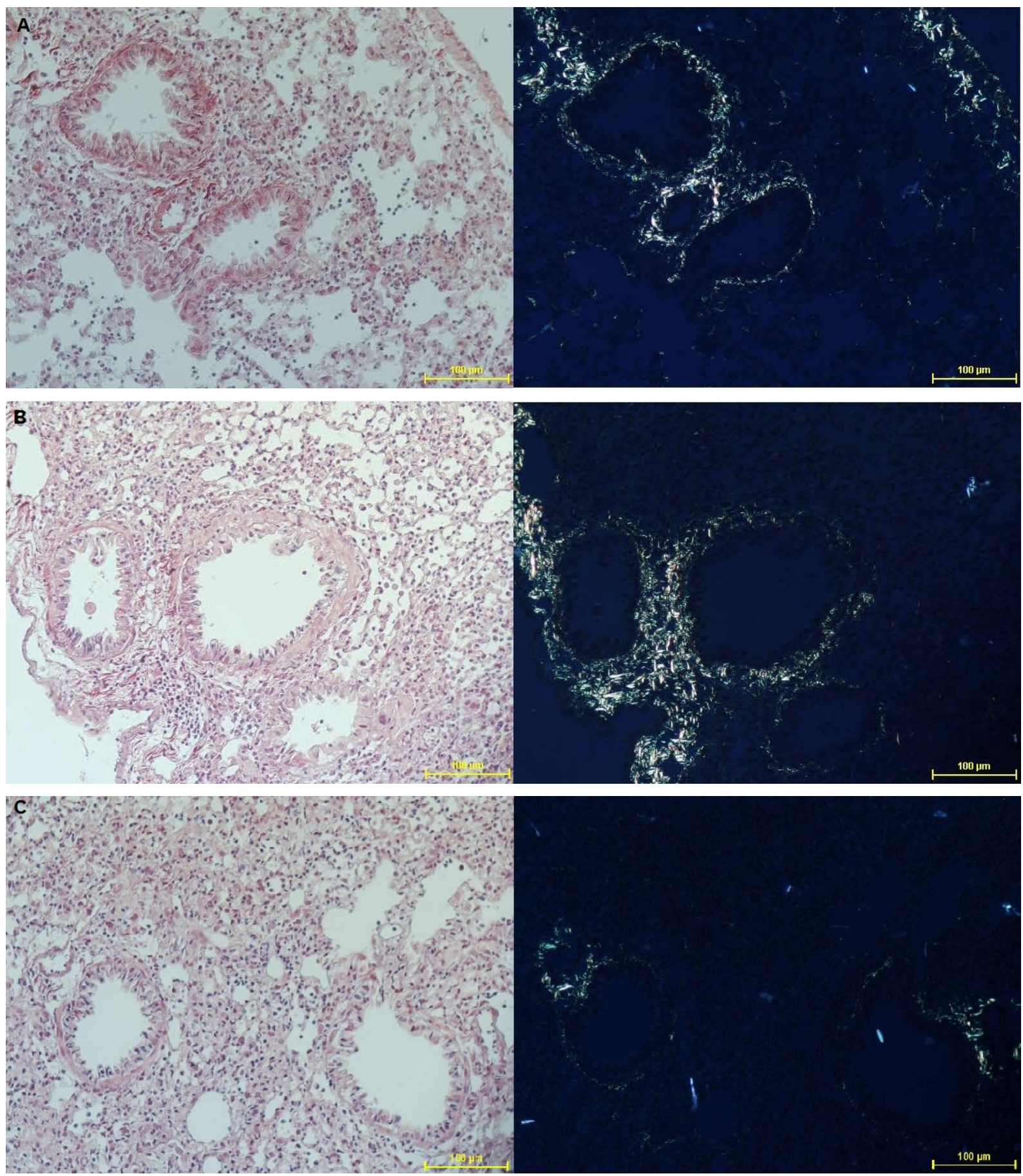


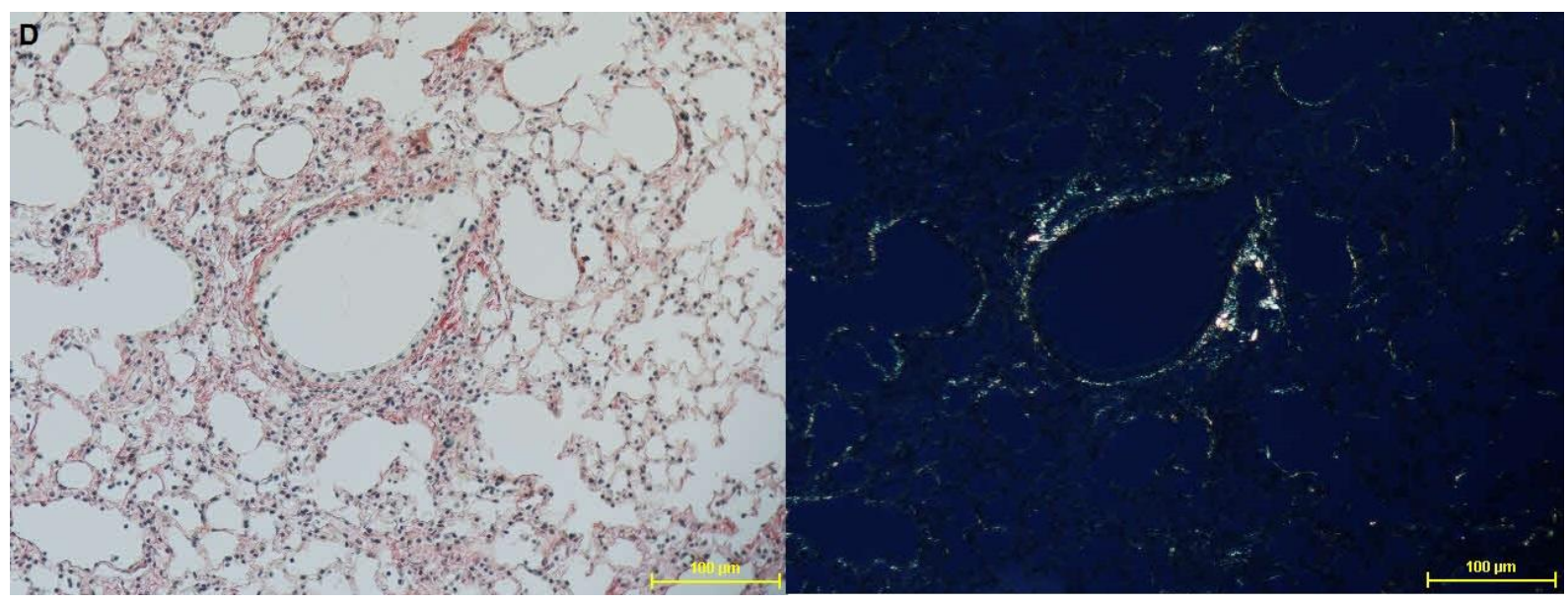

Figura 4. Análise histológica de deposição de colágeno no tecido pulmonar.

Camundongos Ja18 /- e C57Bl/6 estimulados com bleomicina e agonistas das células NKT tiveram seus pulmões retirados após 14 dias para análise de deposição de colágeno através do método de picrosirius. Análise demonstra cortes histológicos do grupo (A) Ja18 //- BLM; (B) WT BLM; (C) WT BLM + aGalCer; (D) WT BLM+Sulfatídeo. Aumento de 20x.
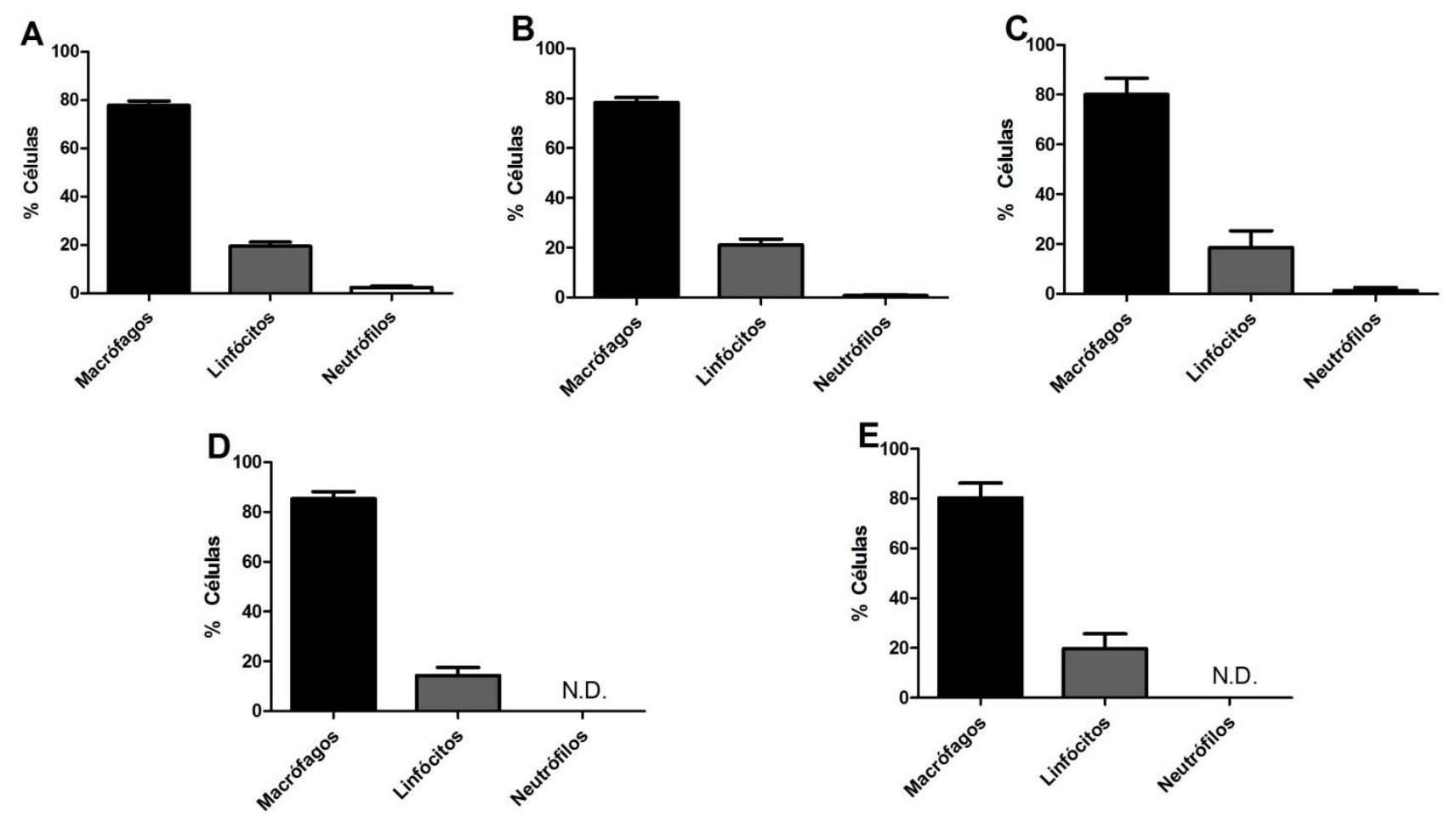

Figura 5. Contagem diferencial de células no BAL. Camundongos selvagens e knockout para células NKT tiveram o fluído pulmonar aspirado após passarem pelo protocolo de fibrose pulmonar. A contagem diferencial de células foi feita por microscopia e está expressa em porcentagem. Os grupos analisados foram (A) SHAM; (B) WT BLM; (C); Ja18 $8^{-/-}$; (D) BLM + aGalCer e (E) BLM + Sulfatídeo. $n=5$ por grupo. 


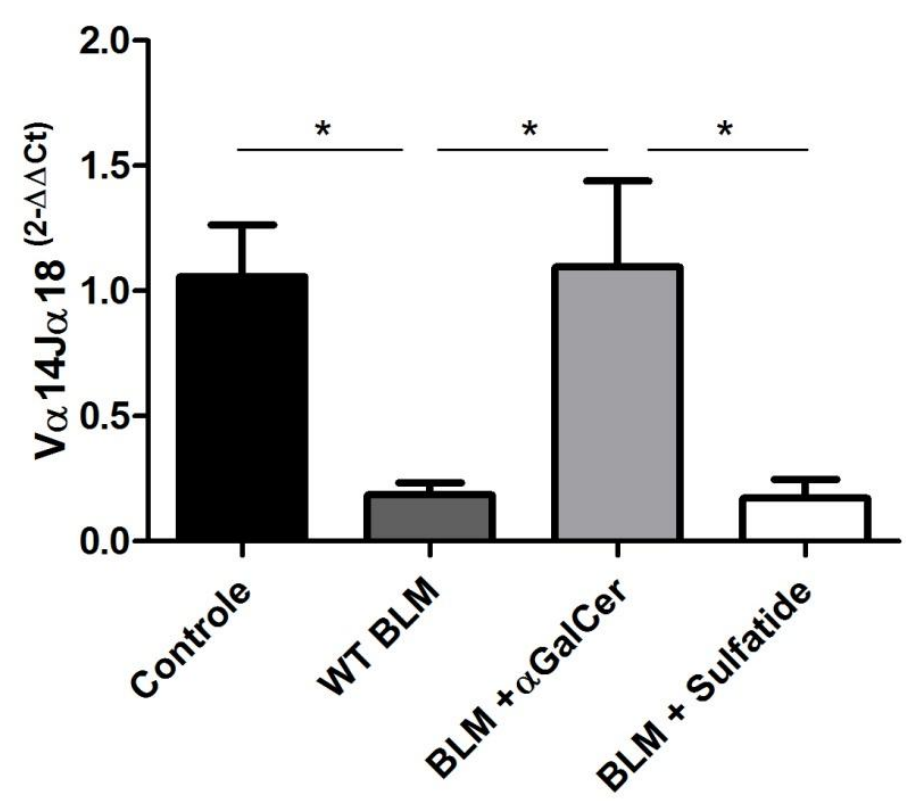

Figura 6. Análise de transcrito gênico. Camundongos selvagens foram estimulados com bleomicina além da administração de agonistas para células NKT. A análise do mRNA tecidual foi avaliada com foco no TCR invariante relativo às células NKT tipo I. ${ }^{*} \mathrm{p} \leq 0.05 . \mathrm{n}=5$ por grupo.

\subsection{Curva de sobrevida nos grupos experimentais}

A análise de sobrevida de camundongos que passaram pelo protocolo de indução de fibrose pulmonar pela bleomicina indica que a deficiência das células NKT como também a utilização de agonistas para as NKT tipo I e NKT tipo II, melhoram a curva de sobrevida, quando comparadas ao grupo experimental que apenas recebeu a bleomicina (Figura 7).

Como de esperado, não foi detectada nenhuma morte nos grupos controles que receberam apenas solução salina de forma intratraqueal. O grupo experimental que recebeu apenas bleomicina teve um elevado número de óbitos que começou a se concretizar após o oitavo dia da administração da droga. Este efeito foi revertido nos grupos que receberam a a-galactosilceramida e sulfatídeo, agonistas para células NKT tipo I e tipo II, respectivamente. Ainda mais, os grupos deficientes para células NKT tipo I também tiveram uma diminuição no número de morte de camundongos, quando comparados ao grupo que recebeu apenas bleomicina (Figura 7). 


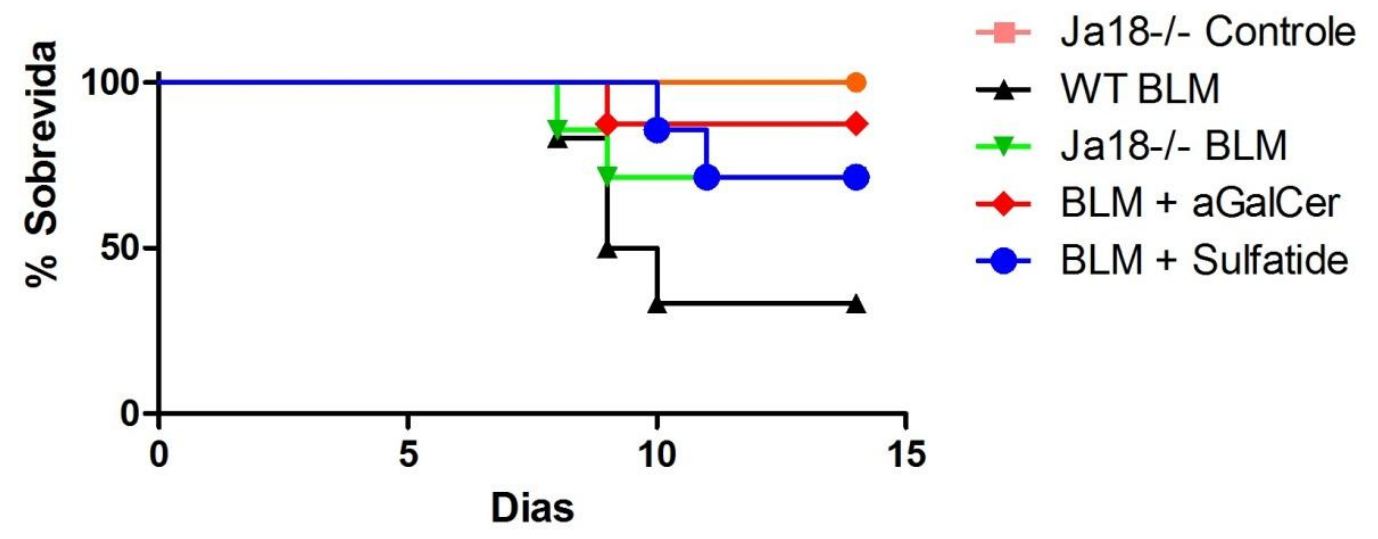

Figura 7. Curva de sobrevida. Camundongos selvagens e knockout para células NKT tipo I foram estimulados ou não com bleomicina, além da administração de agonistas para células NKT. A curva de sobrevida foi baseada na observação de óbito espontâneo dos grupos experimentais. $\mathrm{n}=5$ por grupo.

\subsection{Transcritos gênicos relacionados à fibrose e a inflamação}

Para uma análise global de como o desenvolvimento da fibrose pulmonar atua, é necessário dosar e quantificar citocinas possivelmente envolvidas neste processo para entender o nível molecular da doença.

Nos experimentos, camundongos selvagens estimulados com bleomicina tiveram aumento considerável de TGF- $\beta$ em relação a todos os grupos, com exceção dos animais que receberam a $\alpha$-galactosilceramida (Figura 8A).

Nenhum dos grupos avaliados teve diferença estatística na expressão de mRNA de IL-4 (Figura 9C). No entanto, quando esta proteína é quantificada, podemos perceber que o sinal que é mandado para a síntese proteica a nível transcricional é passado, e a proteína codificada (Figura 9D).

O grupo selvagem que recebeu apenas bleomicina, e apresenta o maior grau fibrótico entre todos os grupos estudados, teve um aumento significante de IL-4 em relação ao grupo knockout para células NKT, os tratados com sulfatídeo, como também o seu respectivo grupo controle (Figura 9D).

De forma a ter uma análise mais completa do padrão Th2, citocinas complementares que são sintetizadas por este grupo celular, como IL-5 e IL-13, foram quantificadas no tecido pulmonar. 
Os resultados alcançados demonstram aumento tanto na quantificação de IL-5, quanto de IL-13 no grupo selvagem que recebeu apenas bleomicina. Desta forma, podemos ter um panorama geral da resposta Th2 que está sendo desenvolvida neste grupo e revertida pela ausência de células NKT, ou até na administração de ativadores das NKT tipo I e tipo II (Figura 13B e 13C).

A polarização da resposta Th1/Th2 é de extrema importância, pois o IFN- $\gamma$ tem efeito anti-fibrótico por inibir a síntese de IL-4 e a consequente ação nos fibroblastos [12]. A quantificação do mRNA, assim como a dosagem proteica do IFN- $\gamma$, não demonstrou diferença estatística entre os grupos (Figura 9A e 9B).

Citocinas pró e anti-inflamatórias foram avaliadas para entender como a inflamação estava se comportando nos animais. Não houve diferença substancial nos níveis de TNF- $\alpha$ entre os grupos estudados (Figura 10A e 10B).

Outra citocina avaliada foi a IL-6 para complementar a análise do processo inflamatório nos animais estudados. Os resultados mostram que o grupo selvagem que apenas recebeu bleomicina como tratamento obteve níveis proteicos aumentados de IL-6, quando comparado ao seu respectivo controle a o grupo knockout, que é considerado protegido. O grupo experimental que recebeu a bleomicina juntamente com o sulfatídeo não apresentou diferença em relação ao grupo tratado apenas com bleomicina (Figura 13A).

Adicionalmente, houve um aumento da regulação da inflamação no grupo que recebeu a a-galactosilceramida, uma vez que há o aumento de IL-10 e maior expressão do fator de transcrição FoxP3 neste mesmo grupo (Figura 1oC e 1oD).

Outro parâmetro interessante a ser analisado é a expressão de vimentina, produto de fibroblastos ativados. Após a indução da fibrose, nenhum grupo experimental apresentou alteração na expressão de mRNA (Figura 8B); Porém, a expressão proteica aumentou significativamente no grupo de animais selvagens que receberam apenas a bleomicina (Figura 11). 

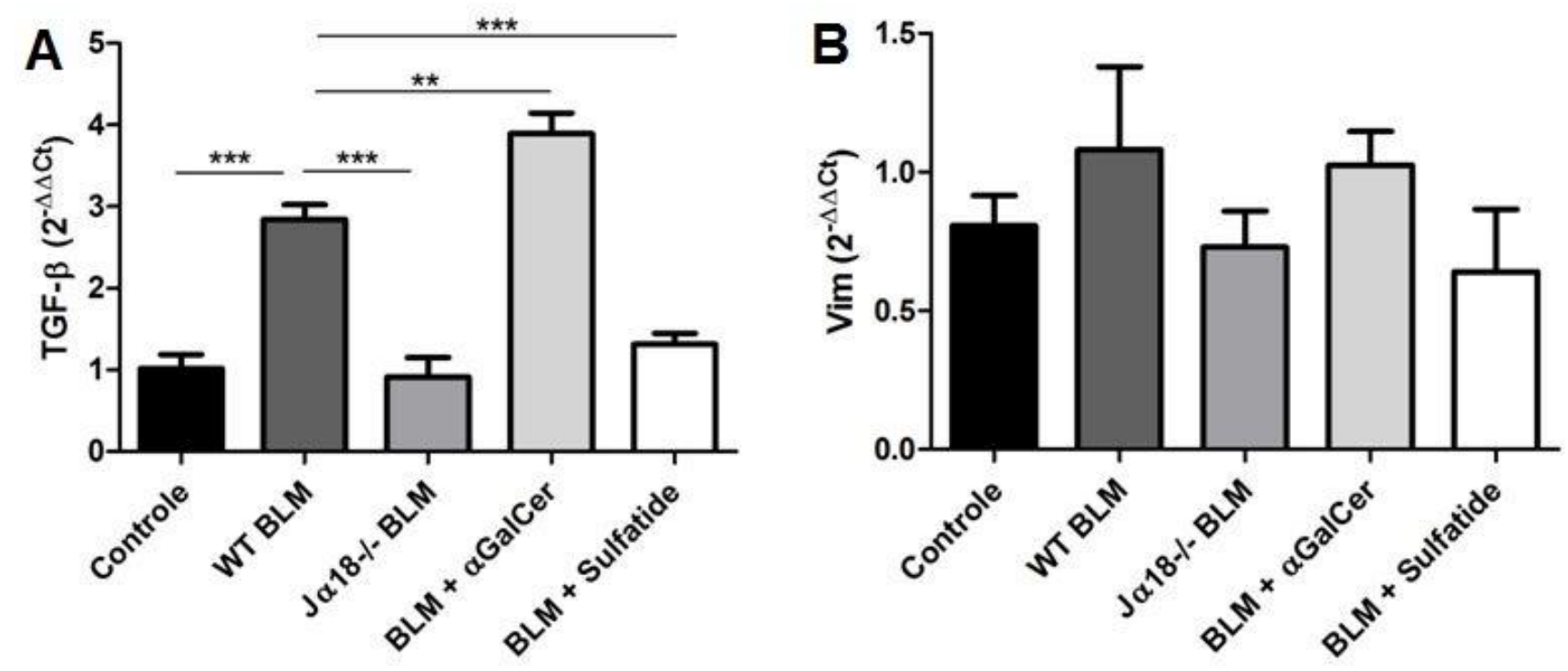

Figura 8. Análise dos transcritos gênicos. Camundongos selvagens e knockouts (Ja18//-) foram estimulados ou não com bleomicina, além da administração de agonistas para células NKT. A análise do mRNA tecidual foi avaliada com foco em citocinas pró-fibróticas, como o (A) TGF- $\beta$ e (B) Vimentina. ${ }^{* * *} \mathrm{p} \leq 0.0001 ;{ }^{* *} \mathrm{p} \leq 0.001 . \mathrm{n}=5$ por grupo. 

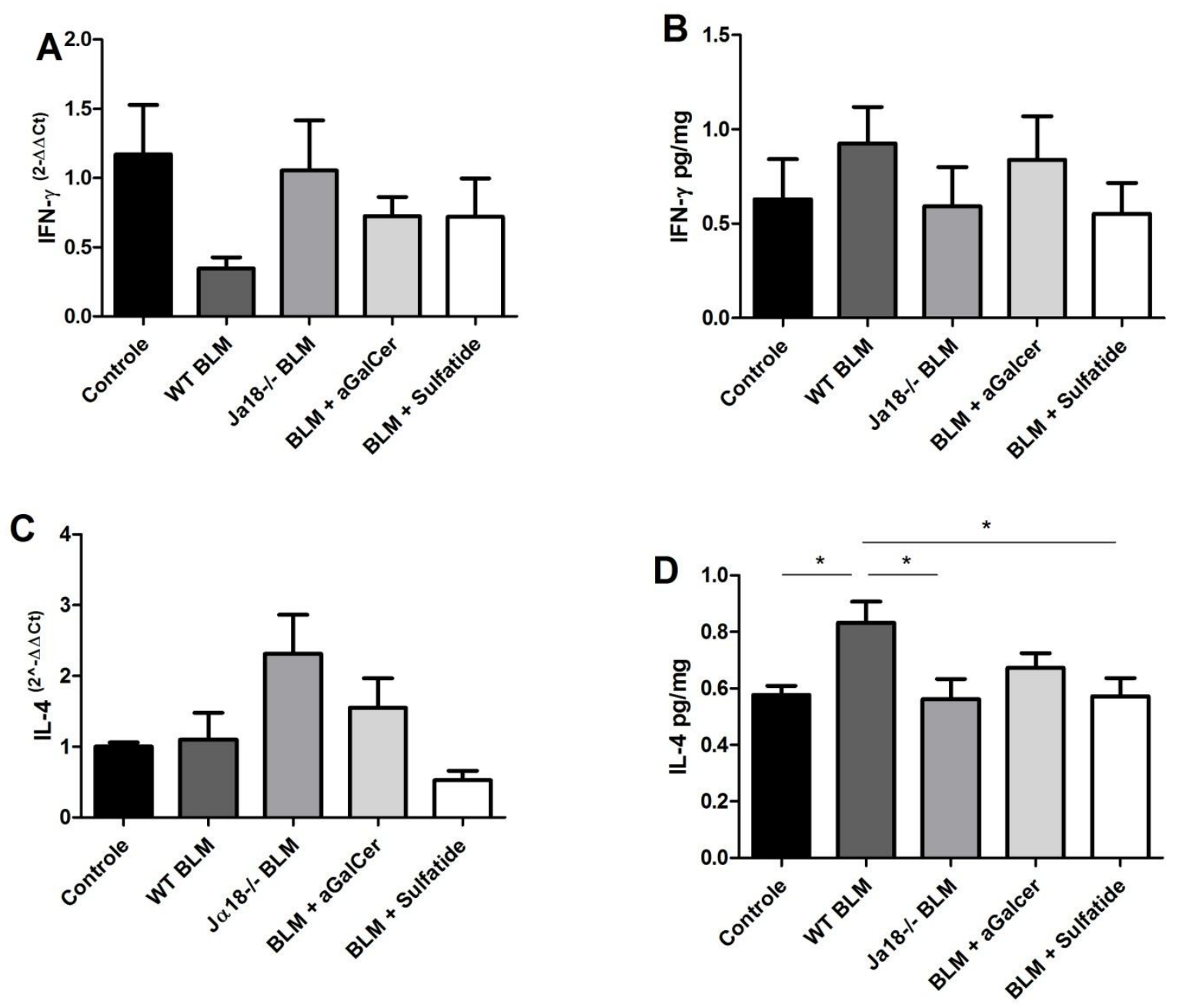

Figura 9. Análise dos transcritos gênicos e quantificação proteica. Camundongos selvagens e knockouts (Ja18 ${ }^{-/-}$) foram estimulados ou não com bleomicina, além da administração de agonistas para células NKT. A análise do mRNA e proteína tecidual foi avaliada com foco em de padrão Th1/Th2, como o (A-B) IFN- $\gamma$ e (C-D) IL-4. ${ }^{*} \mathrm{p} \leq 0.05 . \mathrm{n}=5$ por grupo. 

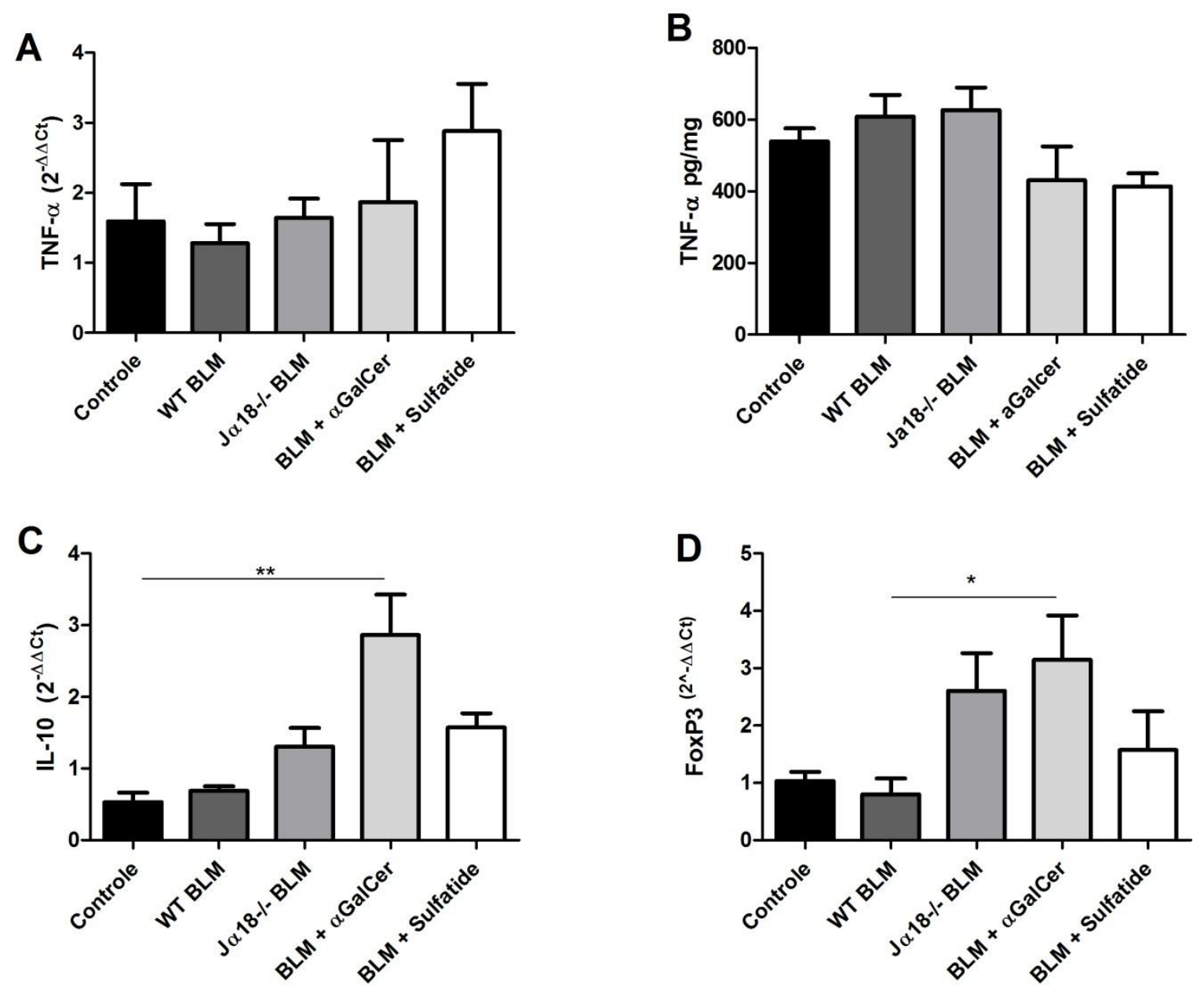

Figura 10. Análise dos transcritos gênicos e quantificação proteica. Camundongos selvagens e knockouts ( $\mathrm{J}_{118^{-/-}}$) foram estimulados ou não com bleomicina, além da administração de agonistas para células NKT. A análise do mRNA e proteína tecidual do TNF- $\alpha$ foram avaliadas com foco citocinas inflamatórias e fator de transcrição regulatório, como o (A-B) TNF- $\alpha$, (C) IL-10 e (D) FoxP3. ${ }^{* *} \mathrm{p} \leq 0.001 ;{ }^{*} \mathrm{p} \leq 0.05 . \mathrm{n}=5$ por grupo. 


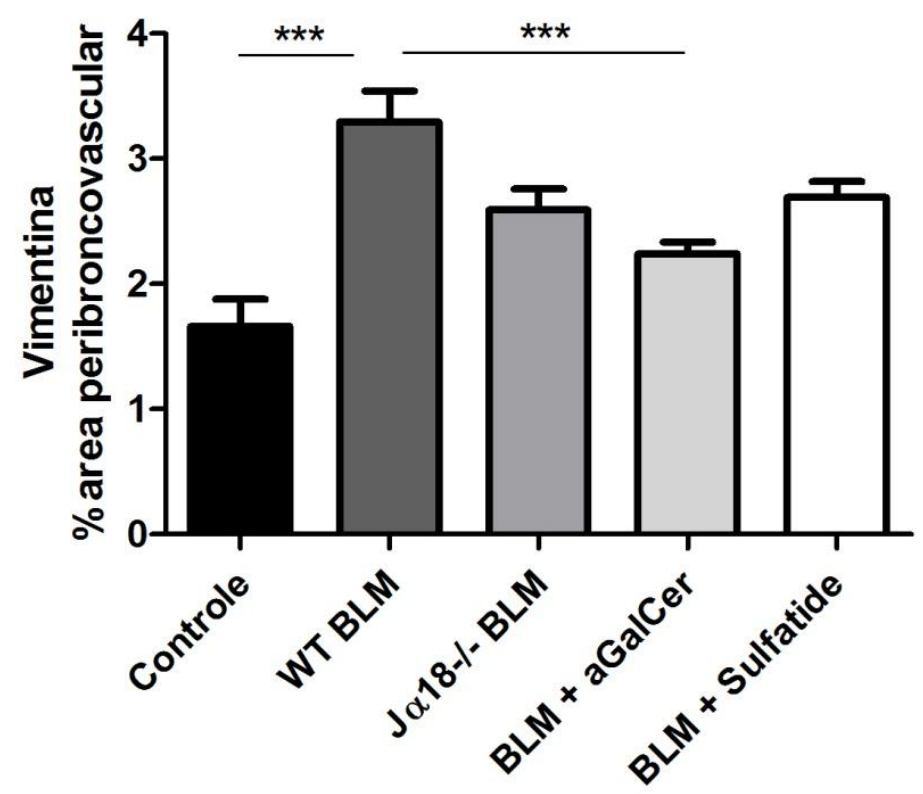

Figura 11. Síntese proteica de vimentina no tecido pulmonar. Camundongos $\mathrm{C}_{57} \mathrm{Bl} / 6 \mathrm{e}$ knockout para células NKT tratados ou não com bleomicina e agonistas para células NKT tiveram vimentina quantificada no tecido pulmonar, após estimulação com bleomicina. O tecido pulmonar foi marcado com anticorpos específicos para vimentina. Os campos marcados positivamente detectados por microscopia foram quantificados de forma aleatória, utilizando-se software adequado. ${ }^{* * *} \mathrm{p} \leq 0.0001 . \mathrm{n}=5$ por grupo.

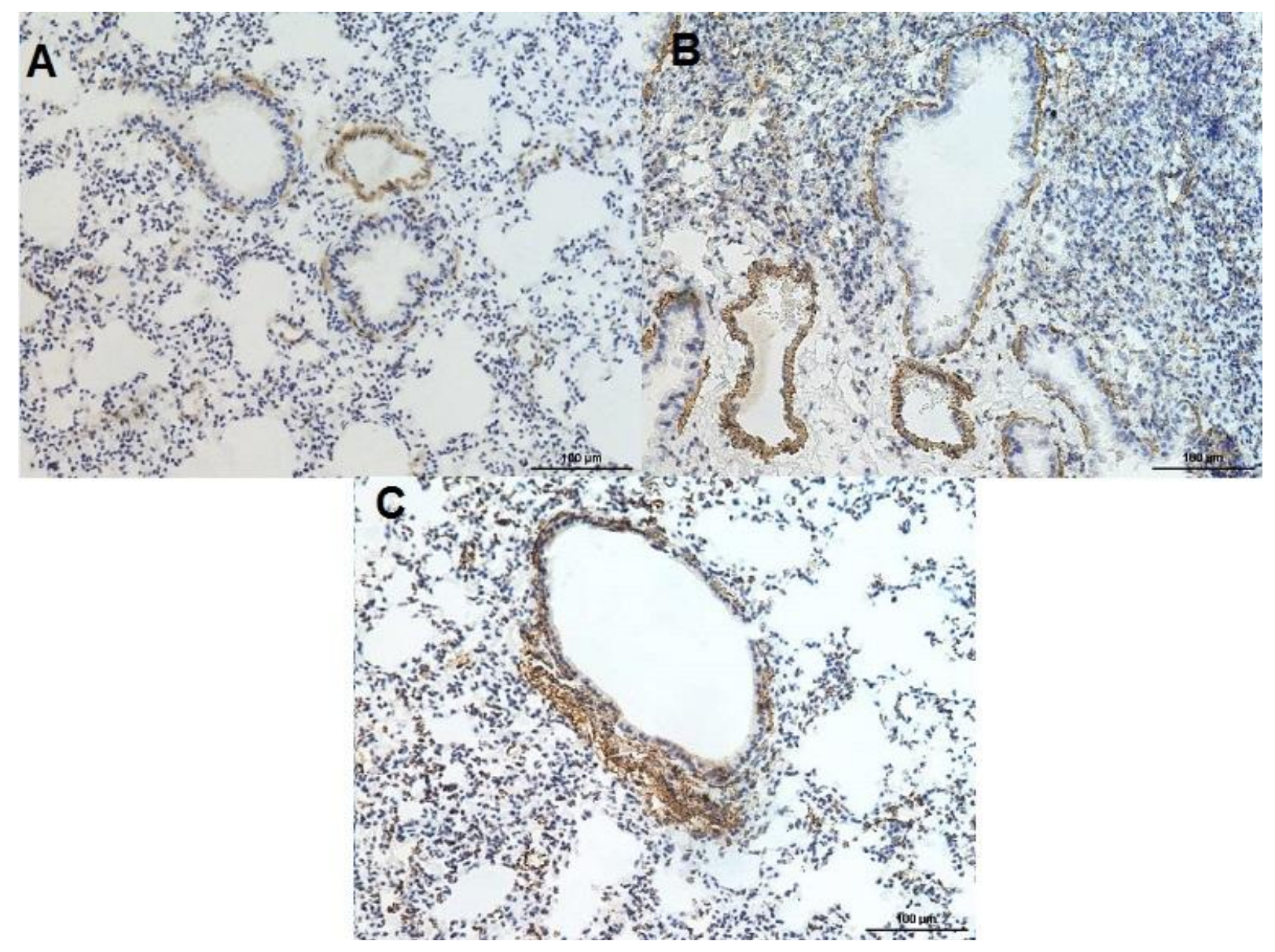




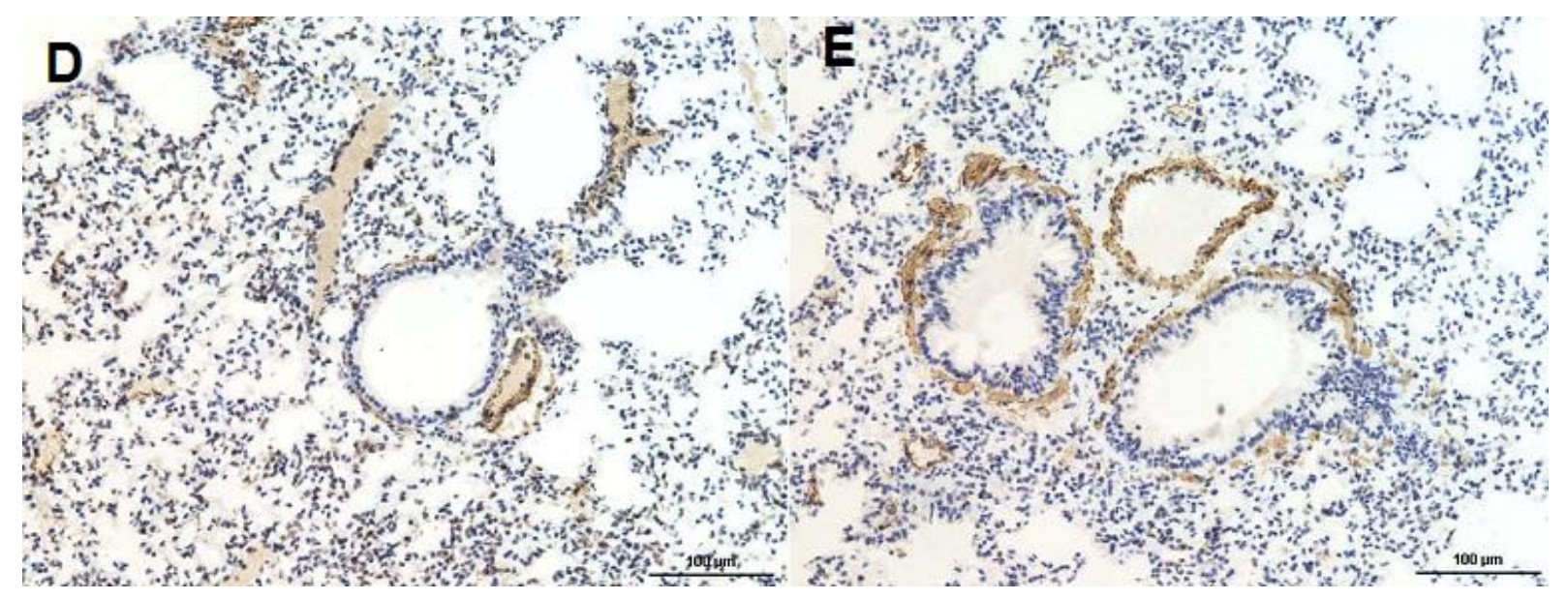

Figura 12. Análise histológica da síntese de Vimentina. Após 14 dias da indução da fibrose pulmonar pela bleomicina, os grupos experimentais tiveram o pulmão retirado para análise de síntese de vimentina pela técnica de imunohistoquímica. Os cortes histológicos envolvem fotos representativas dos grupos experimentais: (A) SHAM; (B) WT BLM; (C) Ja18\%- BLM; (D) BLM + aGalCer e (E) BLM + Sulfatídeo. Aumento de 20x. 

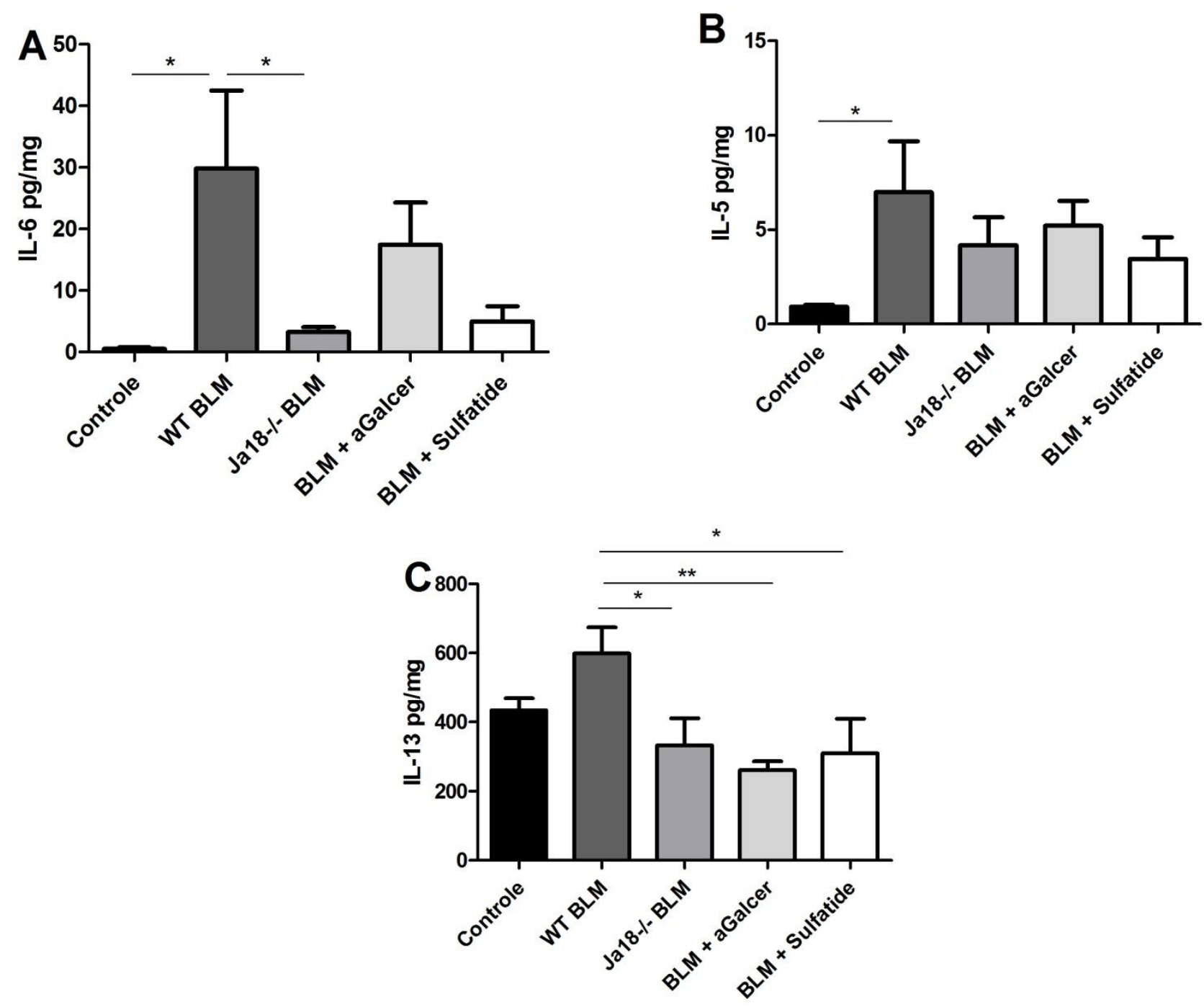

Figura 13. Dosagem proteica. Camundongos selvagens e knockouts (Ja1 $\left.8^{-/-}\right)$foram estimulados ou não com bleomicina, além da administração de agonistas para células NKT. A análise proteica tecidual foi avaliada com foco em citocinas pró-inflamatórias, como a (A) IL-6, e padrão Th2, como (B) IL-5 e (C) IL-13. ${ }^{* *} \mathrm{p} \leq$ 0.001; * $\mathrm{p} \leq$ 0.05. $\mathrm{n}=5$ por grupo. 


\subsection{Estratégia de análise para citometria de fluxo}

No caso dos experimentos feitos, todas as análises aqui demonstradas, passaram pela análise inicial envolvendo um primeiro gate de 'singlets' (Figura 14A), que prioriza células únicas, sem estarem conjugadas a outras células e/ou detritos e, posteriormente, o gate de exclusão de debree, que retira dos gráficos todo o tipo de detrito ou hemácias que poderiam estar presentes na amostra (Figura 14B).

Posteriormente, gates específicos para as células de estudo foram feitos. Para análise fenotípica e funcional de linfócitos TCD4+, os gates usados foram TCR $\beta, \mathrm{CD} 4$, fator de transcrição de células $\mathrm{T}$ reguladoras FoxP3 e citocinas intracelulares como IFN- $\gamma$ e IL-4 (Figura 15).

Para análise de macrófagos, o quadrante duplo-positivo para CD11b e F4/8o foi usado (Figura 16A). A análise fenotípica de macrófagos M1 foi feita através do anticorpo específico contra CD86 (Figura 16B) e para detecção de macrófagos M2, foi usado um anticorpo específico contra CD206 (Figura 16C).

No caso das células NKT, a análise começou com o TCR $\beta$, seguindo para células positivas do marcador NK1.1 e, posteriormente, o tetrâmero do isótipo de CD1, o CD1d, conjugado com o PBS57, análogo a molécula da a-galactosilceramida, permitindo a identificação de células NKT tipo I. A detecção de citocinas intracelulares, como IFN- $\gamma$ e IL-4, também foi feita. (Figura 17). 

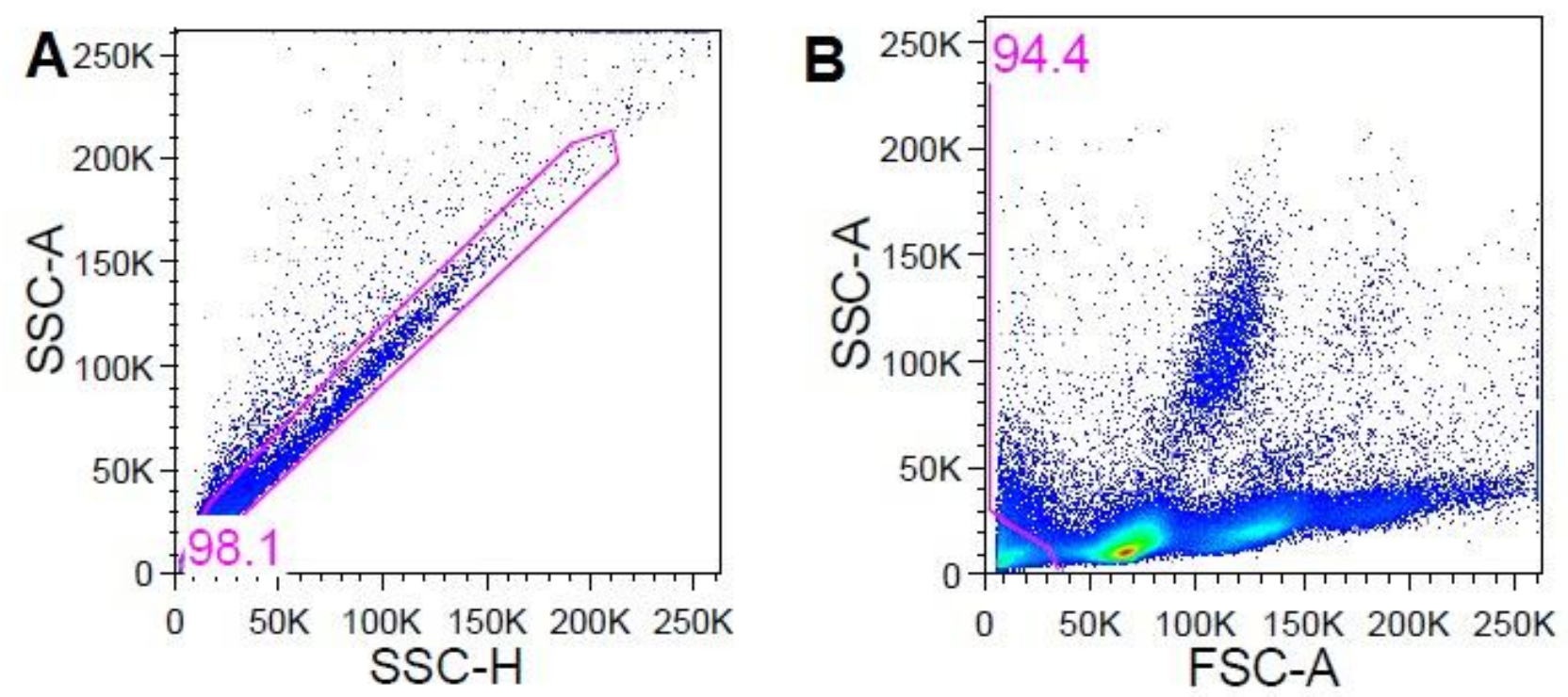

Figura 14. Análise por citometria de fluxo. Gráfico representativo da estratégia de análise para citometria de fluxo. Células foram inicialmente selecionadas em gate de singlets (A) e, posteriormente, o debree encontrado na amostra foi tirado, utilizando um gate de exclusão (B). Células retiradas de tecido pulmonar.
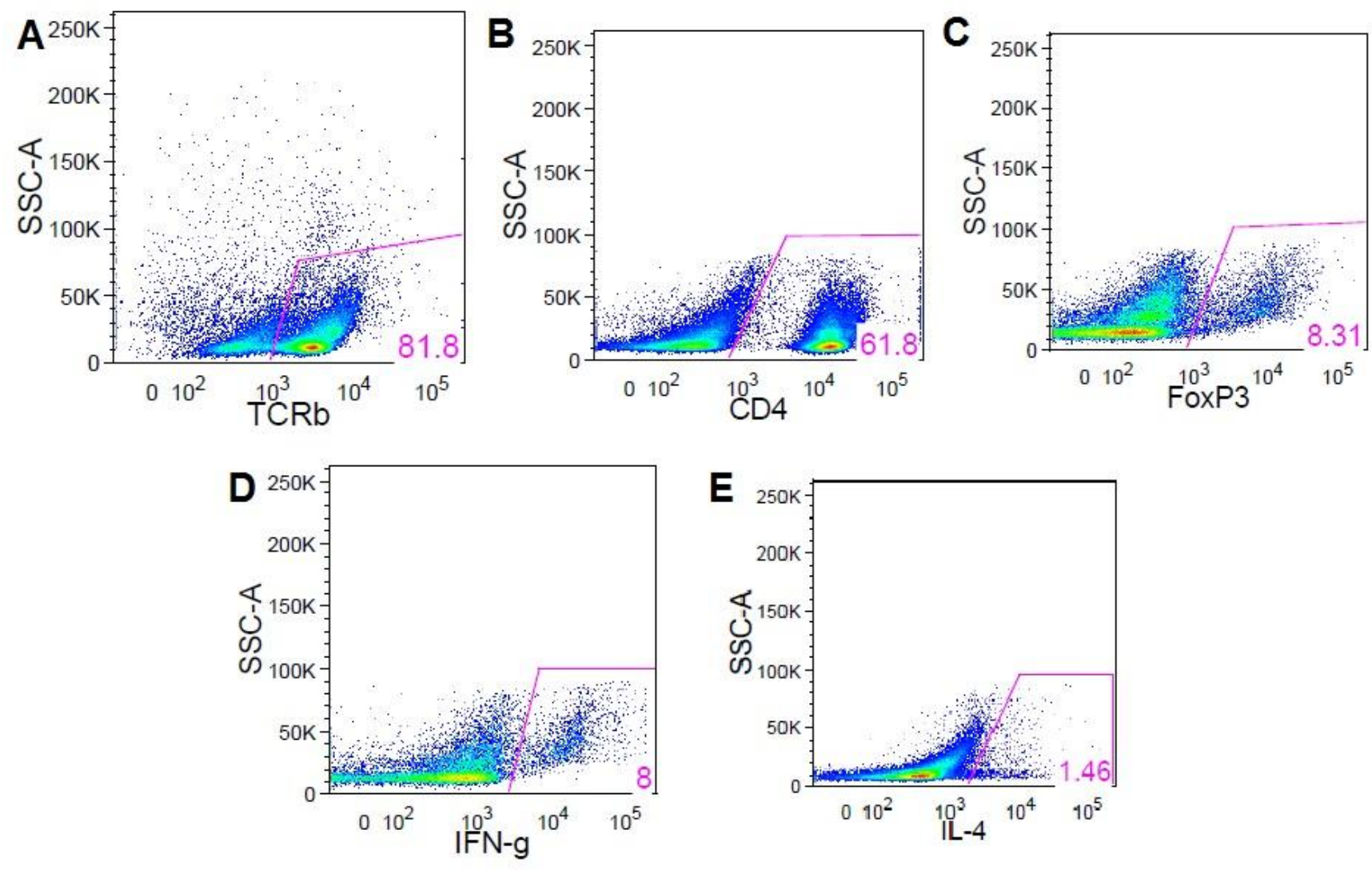

Figura 15. Análise por citometria de fluxo. Gráfico representativo da estratégia de análise de citometria de fluxo com ênfase em marcadores extracelulares e intracelulares de linfócitos TCD4+. Células retiradas de tecido pulmonar. 

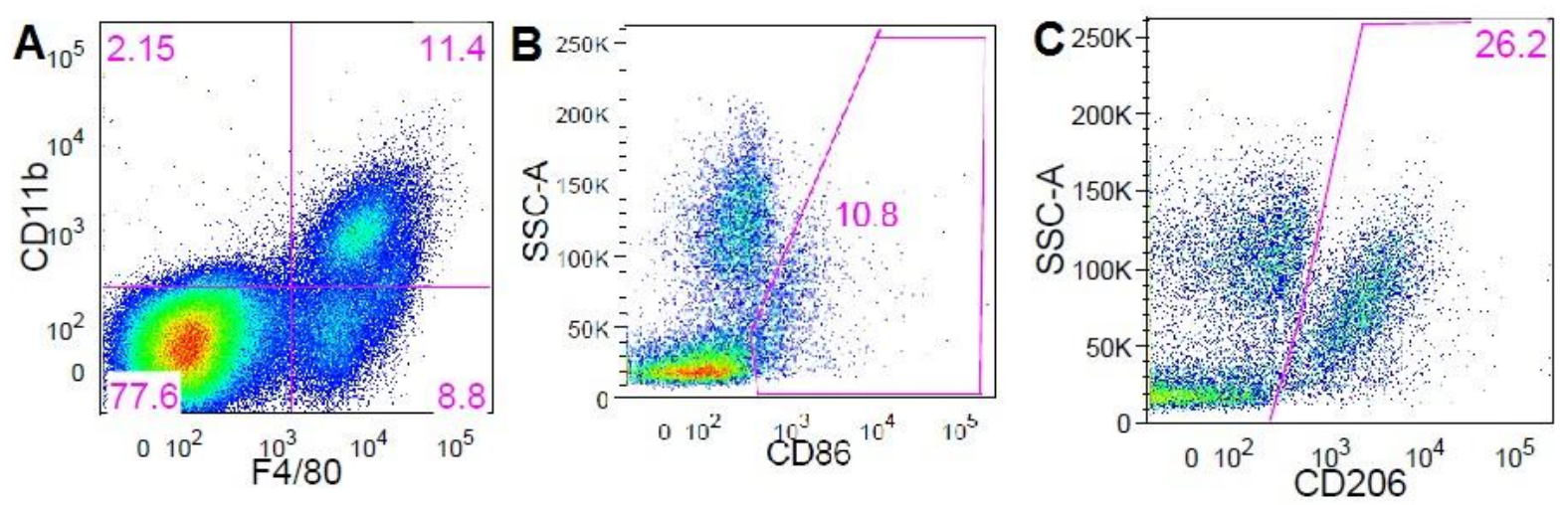

Figura 16. Análise por citometria de fluxo. Gráfico representativo da estratégia de análise de citometria de fluxo com ênfase em marcadores extracelulares para detecção fenotípica de macrófagos. Células retiradas de tecido pulmonar.
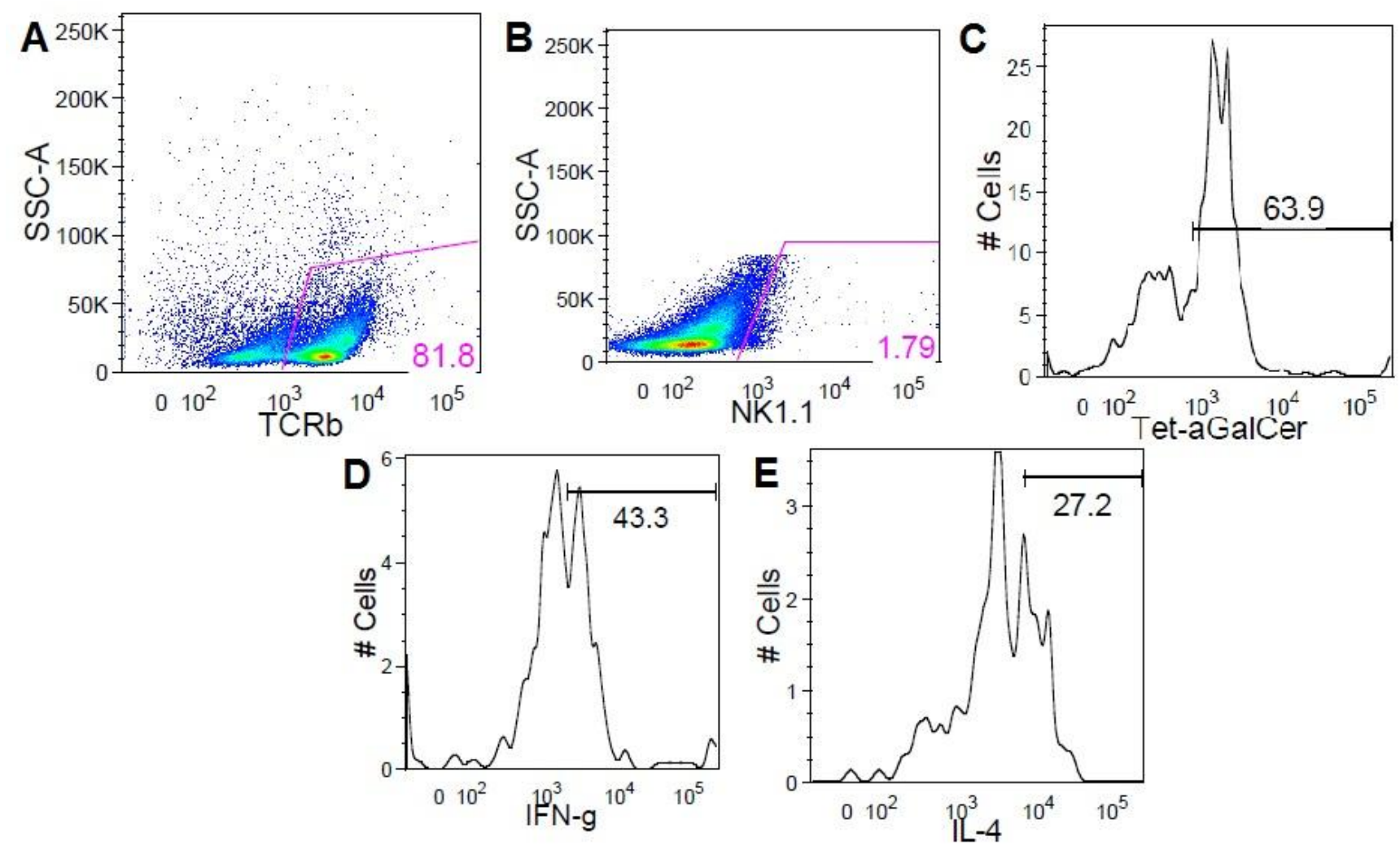

Figura 17. Análise por citometria de fluxo. Gráfico representativo da estratégia de análise de citometria de fluxo com ênfase em marcadores extracelulares e intracelulares de células NKT. Células retiradas de tecido pulmonar. 


\subsection{Regulação de padrão Th1/Th2 é em parte mediada por linfócitos T CD4+}

Após a quantificação proteica e de mRNA de IL-4 e IFN- $\gamma$, identificamos quais populações celulares poderiam estar mediando a regulação Th1/Th2. Os pulmões dos camundongos estimulados com bleomicina, agonistas para células NKT e seus respectivos controles, foram retirados, processados e marcados para análise pelo método de citometria de fluxo.

O IFN- $\gamma$, citocina de assinatura do grupo Th1 das células TCD4+, teve sua síntese diminuída após a instilação intratraqueal da bleomicina nos camundongos selvagens. Entretanto, quando as células NKT tipo I não estavam presentes neste modelo, a quantificação se elevou novamente, comparando-se ao nível basal (controle) (Figura 18A). Este mesmo grupo celular demonstrou um aumento de produção de IL-4 no grupo que não possui células NKT tipo I (Figura 18B). É interessante notar que, quando observamos a quantidade total de IFN- $\gamma$ no tecido pulmonar, não é possível observar diferença entre nenhum dos grupos (Figura 9B), fato que sugere a produção de IFN- $\gamma$ por outros tipos celulares. O inverso acontece com a IL-4. Esta citocina, que tem ação pró-fibrótica, está aumentada no grupo selvagem que recebeu apenas bleomicina e tem o maior grau de fibrose (Figura 9D), sugerindo um padrão Th2 de células no tecido pulmonar.

O outro grupo de células que poderia estar ajudando a regulação Th1/Th2 são as células NKT, que como descrito anteriormente, possuem alto grau de modulação da resposta imune através do perfil de síntese e secreção de citocinas. Nos resultados observados, apenas o grupo que recebeu o sulfatídeo como tratamento secundário a bleomicina possui um aumento de IFN- $\gamma$ mediado pelas células NKT. Nenhuma diferença significativa é observada na síntese de IL-4 pelas NKT tipo I (Figura 18C e 18D). 

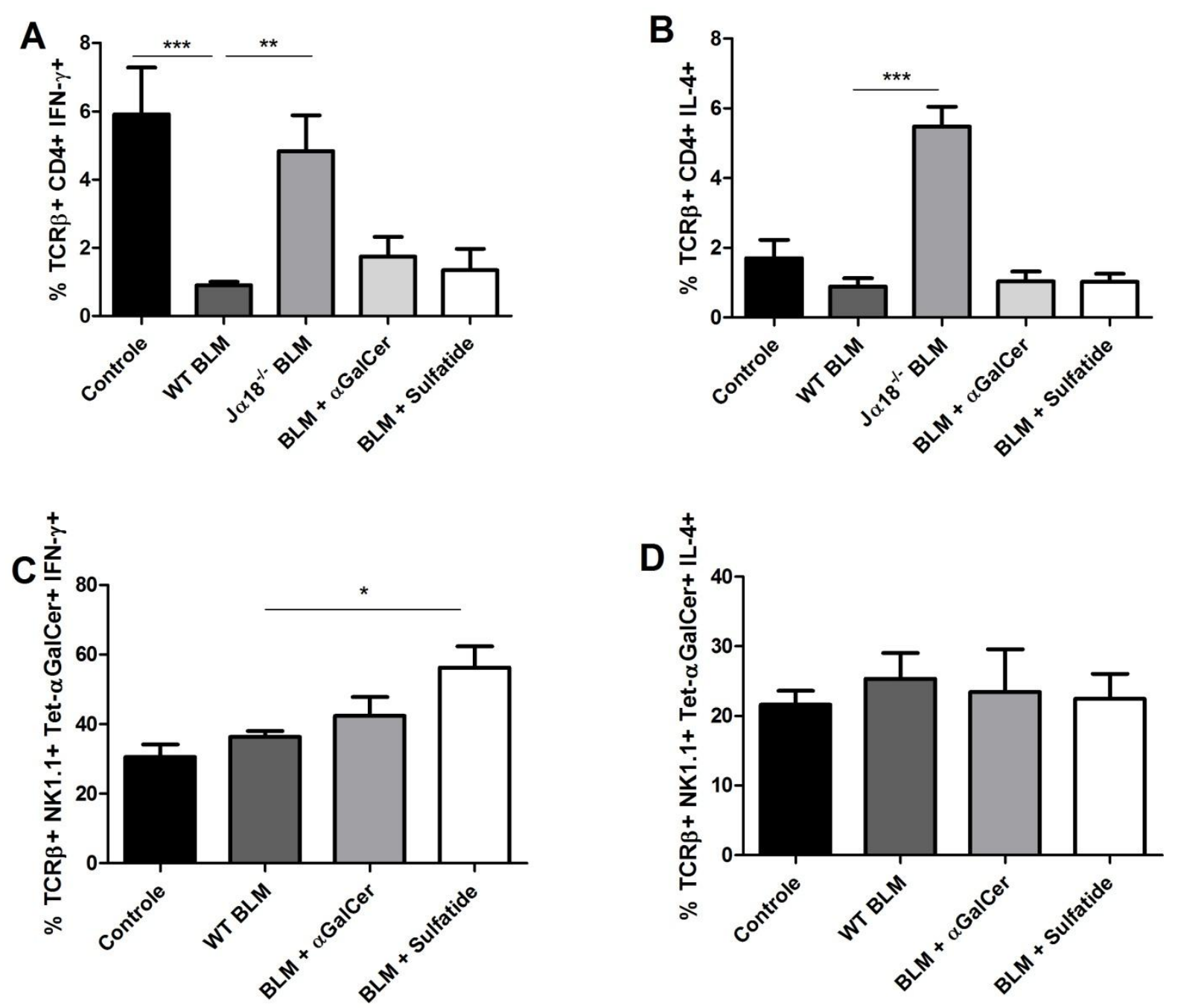

Figura 18. Representação gráfica da análise fenotípica de células TCD4+ e células NKT pelo método de citometria de fluxo. $O$ tecido pulmonar retirado foi processado e marcado com anticorpos para análise fenotípica extracelular de células TCD4+ e NKT, além de análise funcional por marcação intracelular de (A e C) IFN- $\gamma$ e (B e D) IL-4. ${ }^{* *} \mathrm{p} \leq 0.0001 ;{ }^{* *} \mathrm{p} \leq 0.001 ;{ }^{*} \mathrm{p} \leq 0.05 . \mathrm{n}=5$ por grupo.

\subsection{Transcritos gênicos dos fenótipos M1 e M2 nos grupos experimentais}

As análises de quimiocinas, de fatores de transcrição e de produtos de macrófagos podem ajudar na caracterização indireta dos fenótipos dos macrófagos presentes no tecido. A produção da quimiocina MCP-1 aumentou significativamente no grupo que recebeu apenas bleomicina, indicando grande infiltração macrofágica (Figura 19). Este mesmo grupo teve substancial aumento da molécula arginase-1, (Figura 2oD) indicando presença de macrófagos tipo M2 nas amostras estudadas, 
enquanto indicadores do fenótipo M1, como IRF5 e iNOS, não se alteraram em relação ao controle (Figura 20A e 2oB).

Camundongos Ja18\%, assim como os grupos que foram tratados com a $\alpha$ galactosilceramida e sulfatídeo, não tiveram alterações significativas de quimiocinas, IRF5 e iNOS, em comparação aos controles (Figura 19, 20A e 2oB). Porém, é interessante notar que houve uma diminuição da molécula arginase-1 quando estes grupos são comparados com o grupo que recebeu apenas bleomicina (Figura 2oD), o que pode indicar manutenção do fenótipo M1 nestes grupos que são mais protegidos contra a doença.

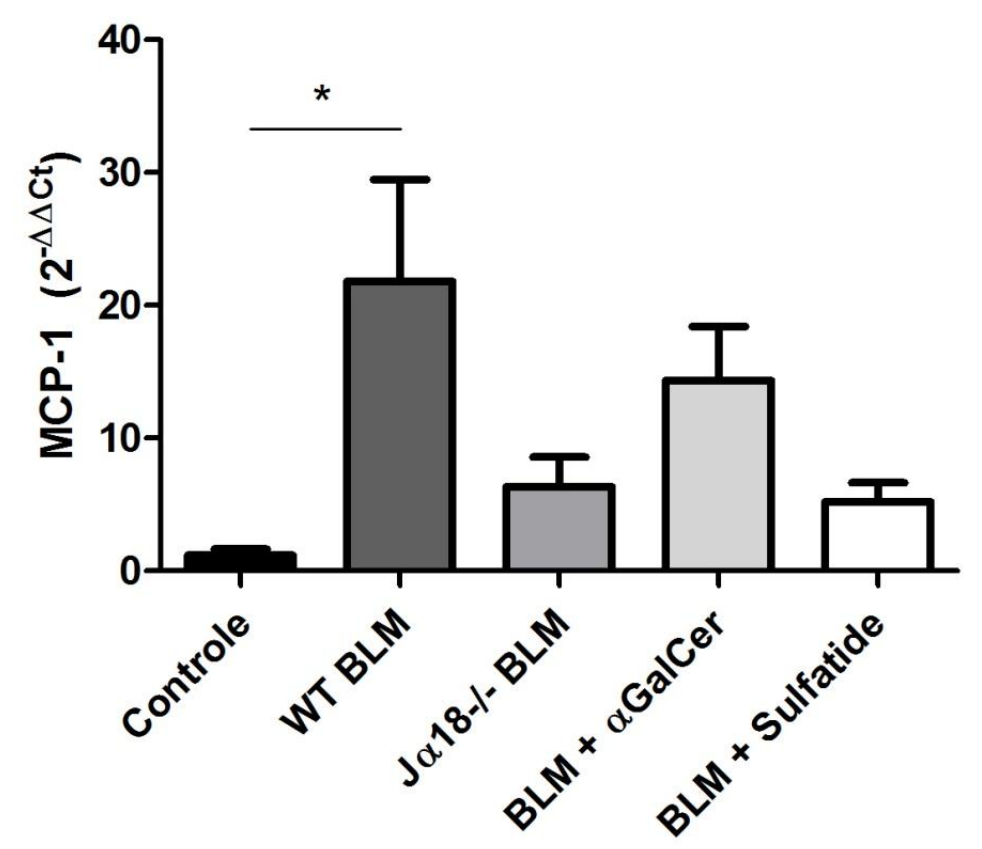

Figura 19. Análise de transcritos gênicos. $O$ mRNA do tecido pulmonar foi extraído e quantificado para análise de recrutamento macrofágico indicado pela quimiocina MCP-1. * $\mathrm{p} \leq 0.05$. $\mathrm{n}=5$ por grupo. 

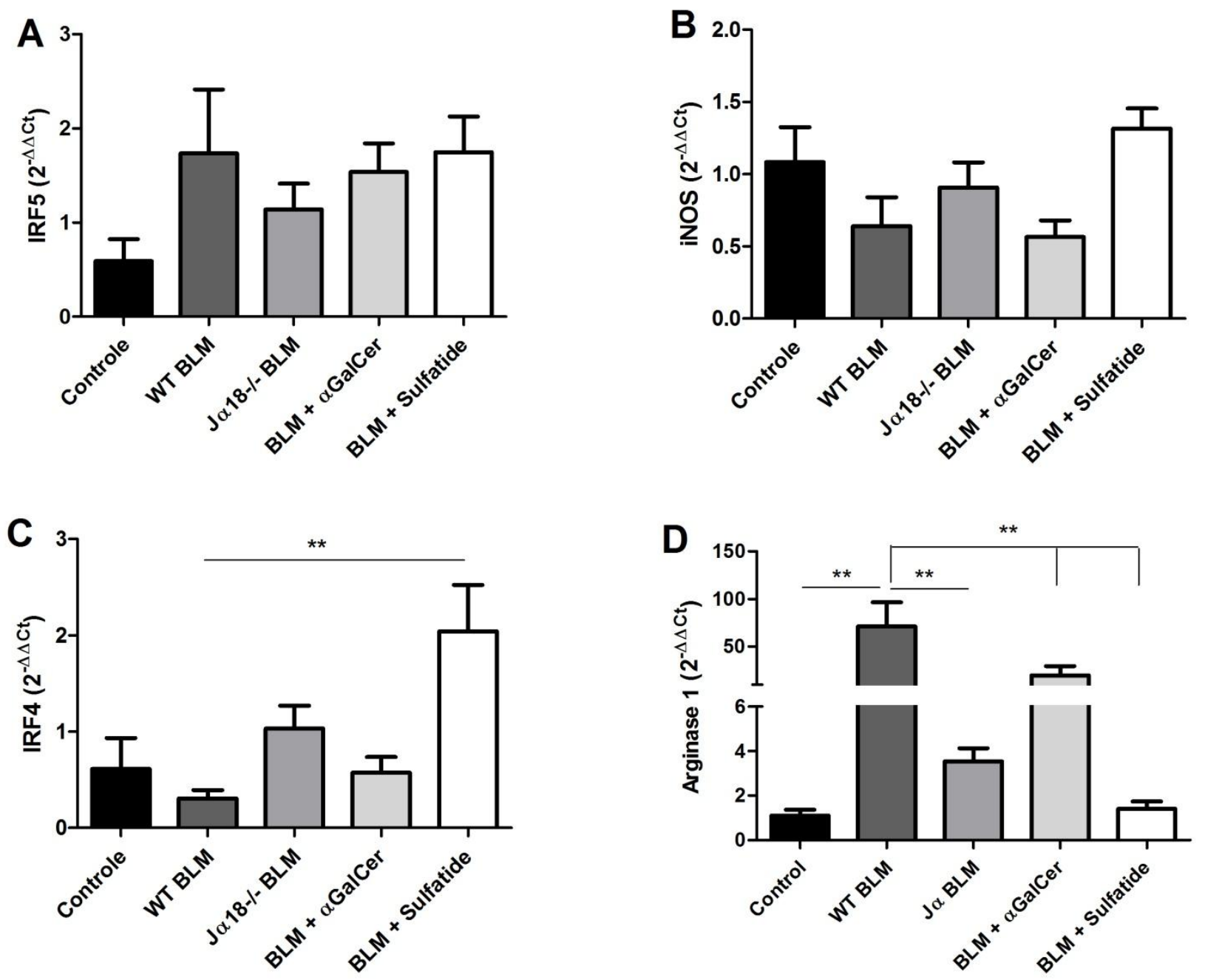

Figura 2o. Análise de transcritos gênicos de produtos e fatores de transcrição relacionados a fenótipo e recrutamento macrofágico. $\mathrm{O}$ mRNA do tecido pulmonar foi extraído e quantificado para análise das vias de ativação macrofágica. Em (A) IRF5 e (B) iNOS, está a via clássica e, em (C) IRF4 e (D) Arginase-1, está a via alternativa, que serve como análise indireta do fenótipo M1 ou M2. ** $\mathrm{p} \leq 0.001 . \mathrm{n}=5$ por grupo. 


\subsection{Identificação fenotípica de macrófagos por citometria de fluxo}

Após análise dos transcritos gênicos que poderiam indicar o fenótipo dos macrófagos no tecido pulmonar, a identificação celular direta por citometria de fluxo se torna necessária para a confirmação fenotípica.

Os resultados atingidos não demonstram nenhuma alteração fenotípica nos grupos experimentais analisados no $14^{\circ}$ dia. A quantificação de macrófagos M1 encontrados no tecido pulmonar não apresenta diferença estatística entre si a não ser pelo grupo que recebeu sulfatídeo, elevando os níveis de fluorescência do anticorpo específico para CD86 (Figura 21A). Seguindo a mesma linha de raciocínio, a análise de macrófagos $\mathrm{F} 4 / 80+$ e CD11b+ que expressam CD206 não apresentou nenhuma diferença significativa entre nenhum grupo, mostrando que, neste período de análise, não houve diferença (Figura 21B).

Os resultados encontrados neste trabalho demonstram que a via da arginase-1 está ativada em camundongos que possuem alto grau fibrótico, e diminuída nos grupos protegidos (Figura 2oD), enquanto o produto de macrófagos M1 continua em seu estado basal em todos os grupos estudados (Figura 2oB). De forma análoga, a detecção por citometria de fluxo não detectou diferença na expressão de CD86 (marcador para M1) e nem de CD206 (marcador para M2) (Figura 21).
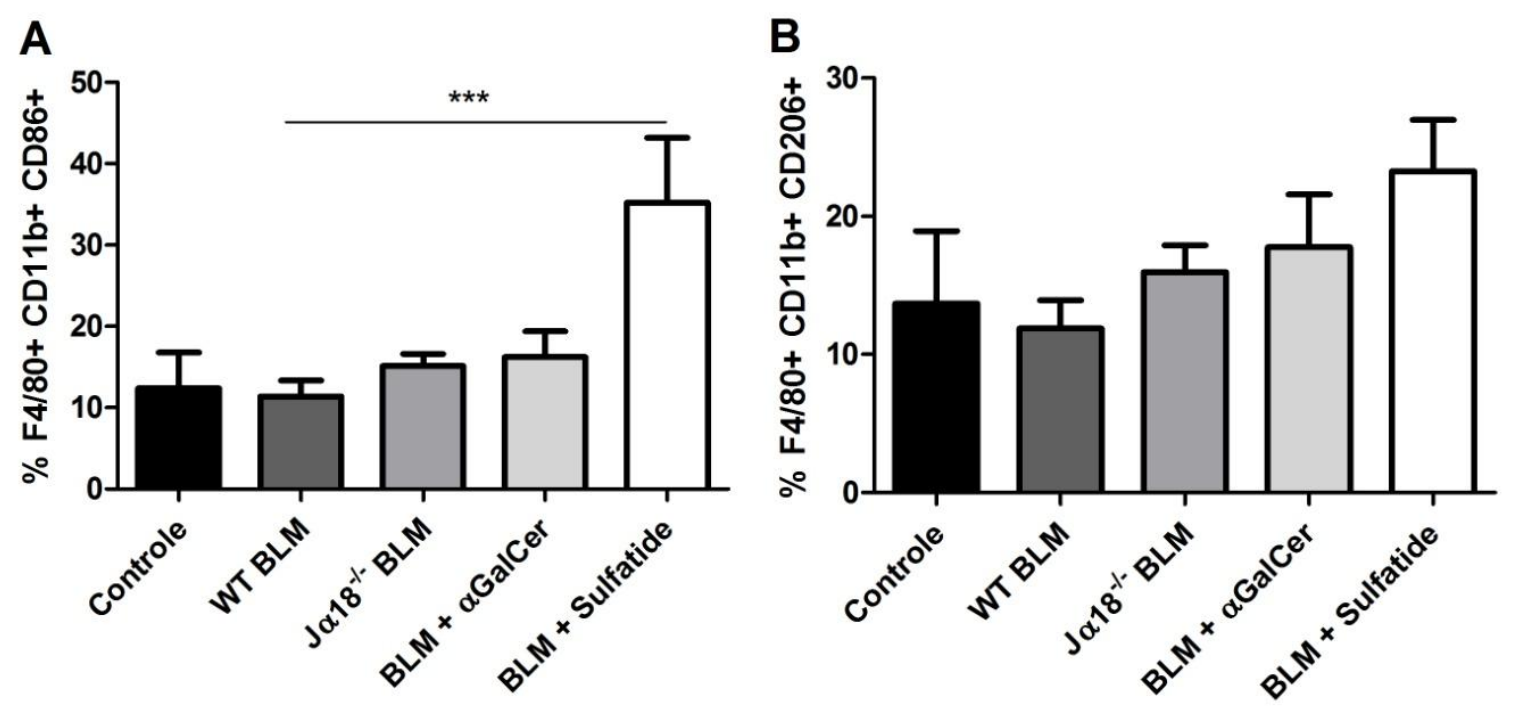

Figura 21. Representação gráfica da análise fenotípica dos macrófagos pelo método de citometria de fluxo. $O$ tecido pulmonar retirado foi processado e marcado com anticorpos para detecção de macrófagos (A) M1 e (B) M2. ${ }^{* * *} \mathrm{p} \leq 0.0001 . \mathrm{n}=5$ por grupo. 


\section{DISCUSSÃO}

A fibrose pulmonar é a sequela final de uma variedade de patologias, que incluem a injúria pulmonar resultante da inalação de poeira, radiação, drogas e de doenças sistêmicas e pulmonares. A fibrose pulmonar idiopática, também é descrita como um dos tipos de fibrose, e que surgem sem motivo aparente [1].

Os pacientes mostram os sintomas de forma tardia no curso da doença. $\mathrm{O}$ tratamento atual envolve imunossuprossores assim como corticoesteróides, mas esta abordagem terapêutica não se demonstrou eficaz no prognóstico, o que continua levando cerca de 50 \% do pacientes a óbito após 5 anos do diagnóstico [1]. Desta forma, todos os estudos que visam os entendimentos celulares e moleculares da doença se tornam importantes por visarem uma melhora da qualidade de vida e redução no número de óbitos de pacientes com esta doença.

O passo inicial do estudo foi a padronização do modelo animal que seria utilizado. O intervalo de tempo parece ser um fator chave, uma vez que, quanto mais duração para o efeito da droga, maiores níveis de hidroxiprolina são detectados. Outros estudos também demonstraram reproduzir a FPI em camundongos utilizando-se a dose de $5 \mathrm{mg} / \mathrm{kg}$ [47; 48] refletido também pelo aumento da síntese de hidroxiprolina e deposição de colágeno após 14 dias ou mais de exposição à droga $[49 ; 50 ; 51]$, o que corrobora os achados do presente trabalho.

A bleomicina tem uma preferência pelo epitélio pulmonar, vez que este órgão apresenta níveis menores da hidrolase da bleomicina, o que influencia diretamente a ação do medicamento neste órgão, além do fato do efeito adverso deste químico no pulmão ser dose-dependente [20]. Os experimentos realizados mostram que, depois de duas semanas, os camundongos tiveram fibrose consistente (evento não detectado no grupo de 7 dias). Além disso, não foi detectada diferença significativa entre os grupos de 14 e 21 dias.

A literatura relata que um bom modelo animal deve reproduzir a doença humana em níveis moleculares e celulares de uma maneira que uma hipótese possa ser testada. Tendo as características da FPI presentes no grupo estimulado por 14 dias, este modelo foi escolhido para servir como base experimental para todo o estudo deste projeto, duração que também parece ser o mais frequente em experimentos envolvendo este estudo em animais [52]. 
O próximo passo foi avaliar os parâmetros fibróticos nos grupos experimentais. O read-out dos experimentos para constatação ou não da fibrose foram baseados na síntese e quantificação de hidroxiprolina e colágeno.

Pelo método de microscopia, foi detectado uma predominância de macrófagos (cerca de 80\%), seguido pela presença de linfócitos (cerca de $20 \%$ ) no tecido pulmonar. Estes padrões celulares eram esperados, pois se relacionam com resultados observados em outro estudo que utiliza a bleomicina de forma intratraqueal [77].

A detecção de células NKT não pode ser feita por microscópio por não apresentar nenhuma diferença morfológica ao olho nu. Para a identificação destas células a amplificação do primer da parte invariante do TCR destas células foi detectada através do método de RT-PCR.

O uso do a-GalCer aumentou a amplificação do primer indicando ativação destas células, justamente por ser um agonista das NKT tipo I. O grupo que recebeu o tratamento com sulfatídeo tem a expressão do primer diminuída. Este resultado é esperado, considerando que a literatura demonstra que a ativação das células NKT tipo I regulam negativamente a ativação das células NKT tipo II [29, 30].

As células NKT têm sido descritas na literatura como importante fonte de IL4, podendo polarizar uma resposta imune para padrão Th2. Estudos envolvendo a deficiência deste grupo celular apresentam menores níveis de resposta Th2, o que influencia o fenótipo das células $\mathrm{T} \mathrm{CD}^{+}+$[53], impedindo a polarização para o fenótipo $\mathrm{T}$ helper 2. A liberação primária deste padrão de citocinas poderia influenciar uma resposta imune tardia, o que pode explicar a proteção no grupo $\mathrm{Ja18} /-$.

O uso da a-galactosilceramida como substância imunomodulatória é cada vez mais atraente, pois tem a propriedade de direcionar a resposta imunológica para padrões diferentes, criando mudanças fisiológicas a partir de modelos comportamentais nas células do sistema imune. Como descrito anteriormente, este componente tem grande eficiência na ativação das células NKT tipo I (iNKT). Estas células têm a capacidade de sintetizar e liberar citocinas de padrão Th1 e Th2 como IFN- $\gamma$ e TNF- $\alpha$ além de IL-4 e IL-13, respectivamente. De forma particular, as iNKT podem produzir citocinas de padrão Th1 e Th2 simultaneamente após a estimulação in vivo [54]. 
O reconhecimento do complexo binário CD1d-KRN 700 pelo TCR causa uma resposta branda de padrão Th1; porém, a capacidade deste agonista induzir uma resposta Th1 ou Th2 em diversas situações parece depender da célula APC, responsável por carregar este glicolipídio. Linfócitos B desencadeiam uma resposta com maior porção Th2, enquanto que a apresentação via célula dendrítica polariza a um padrão Th1 [45].

Outro ponto a ser considerado é que o comportamento biológico da $\alpha$-GalCer parece ser tempo-dependente, levando a produção de citocinas de padrão Th2 em uma resposta aguda, enquanto que uma resposta crônica direcionaria a uma polarização contrária [45], o que poderia explicar a proteção conferida neste modelo de fibrose após 14 dias de estimulação com a bleomicina.

A ativação das células NKT tipo II pelo uso do sulfatídeo também conferiu proteção aos camundongos expostos ao protocolo de indução da fibrose pulmonar fato que também pode ser observado em camundongos knockout para NKT tipo I (Ja18//-). A literatura fornece dados que demonstram uma regulação oposta entre estes dois tipos celulares caracterizados por uma anergia funcional após a ativação de um dos grupos de NKT. Em modelo experimental de imunidade contra tumores onde os dois grupos de NKT foram estimulados, o efeito protetor contra o tumor conferido pelas NKT tipo I foi suprimido pela ativação das NKT tipo II; evento observado in vitro e in vivo [30]. O fenótipo anérgico das NKT tipo I também foi detectado após ativação por sulfatídeo das NKT tipo II em modelo de inflamação hepática [29]

O estudo das NKT tipo II ainda permanece um desafio. A dificuldade de identificar este tipo de célula através dos seus marcadores impossibilita avanços nas pesquisas que focam este tipo celular. No entanto, é bem descrito que estas células, assim como as NKT tipo I tem um grande potencial imunomodulatório após ativação com sulfatídeos, conferindo um comportamento único nas respostas imunes. Além disso, as NKT tipo II tem sido colocadas em alvo como um possível potencial terapêutico, focando a imunomodulação de doenças, justamente por não apresentar regiões de polimorfismo na isoforma CD1d [55].

Os estudos que focam os diversos tipos de fibrose tem como base o entendimento das bases moleculares e celulares para a melhor sobrevida de pacientes portadores de uma determinada doença. Tendo este argumento como base, a observação de morte espontânea após a indução de fibrose pela bleomicina foi feita para análise de sobrevida dos animais. 
Como descrito anteriormente, a fibrose pulmonar idiopática é a mais comum das pneumonias com um prognóstico envolvendo elevados níveis de óbito (50\%70\%), após o diagnóstico [10, 11]. Por se tratar de uma doença com incidência relativamente alta e englobar uma série de sintomas que agravam a qualidade de vida, como tosse improdutiva, esforço ao respirar e deficiência pulmonar [10, 11, 12], os estudos que visam procedimentos para uma melhora fisiológica e respiratória assim como o foco na diminuição de óbitos em pacientes, se tornam de total validade considerando-se que a doença em questão não possui um tratamento terapêutico efetivo.

Os resultados encontrados em relação a sobrevida dos animais estudados (Figura 7) são corroborados por outro modelo experimental que mostra o potencial de dano feito pela bleomicina e diminui a sobrevida de camundongos [78]. A literatura é bem categórica no sentido que a bleomicina causa apoptose celular, regeneração tecidual desregulada e, consequentemente, deposição de colágeno e perda de funcionalidade pulmonar [79]. Desta forma, podemos correlacionar o índice de sobrevida dos grupos experimentais com a deposição de colágeno observada nos resultados anteriores. Portanto, quanto maior deposição de colágeno, maior é a perda funcional do órgão, o que acaba evoluindo para óbito. Como visto anteriormente, os grupos experimentais que são considerados protegidos tiveram menor deposição de colágeno e, portanto, maior sobrevida.

Após verificar o perfil celular que está envolvido no desenvolvimento da doença, o nosso próximo passo foi identificar as citocinas pró e anti-inflamatórias bem como citocinas que podem estar influenciando o fenótipo fibrótico ou a própria regulação deste cenário.

Diversas citocinas podem fazer parte dos processos fisiopatológicos envolvidos no organismo humano em resposta aos mais diversos estímulos. O TGF- $\beta$ é uma das citocinas chaves responsáveis em regular o fenótipo dos fibroblastos. Quando ocorre liberação desta molécula, os fibroblastos se transformam em miofibroblastos, uma das células essenciais no cenário fibrótico. Estas células fazem parte de um processo complexo de reparação em caso de dano tecidual; porém, em situações de desequilíbrio, podem ser responsáveis por mediar o surgimento da fibrose [43].

A literatura demonstra que, em modelos de fibrose pulmonar induzida pela bleomicina, o mRNA do TGF- $\beta$ também é encontrado em níveis aumentados [56; 
57] o que corrobora os dados obtidos. Estudos também demonstram que o aumento da expressão desta molécula através do uso de um vetor viral resulta em fibrose progressiva intersticial crônica [58]. Além disso, camundongos knockout para Smad3, transdutor de sinal desta molécula a partir da membrana celular até o núcleo, apresenta diminuição da expressão de mRNA de colágeno tipo I e diminuição da síntese de hidroxiprolina após estimulação com bleomicina [59], o que mantém a ideia de que o TGF- $\beta$ é uma das citocinas chaves neste processo patológico.

Subtipos de fibroblastos humanos e de camundongos demonstraram produzir proteínas da MEC in vitro, colágeno tipo I e tipo III e fibronectina após interação do IL-4 com seu próprio receptor na membrana destas células. Em um modelo experimental de esclerodermia, inibidores de IL-4 foram capazes de reduzir o desenvolvimento da fibrose dérmica. Além disso, altos níveis de IL-4 podem ser encontrados no BAL de pacientes que apresentam FPI [6o]. Esta citocina exerce sua função quando se liga ao receptor de IL-4 presente na membrana celular e promove a dimerização da cadeia $\alpha$ (IL-4R $\alpha$ ) e da cadeia comum gama $(\gamma c)$.

A fosforilação de resíduos de tirosina é orquestrada por quinases e leva a ativação do gene STAT6. Quando este fator atinge o núcleo, se adere ao loci específico no cromossomo, aumentando a expressão de IL-4, IL-5 e IL-13 [61], fortalecendo o processo de polarização para a via Th2 e assim acaba promovendo a deposição de colágeno pelos fibroblastos [16].

Em outro estudo científico utilizando a bleomicina como indutor da fibrose pulmonar, a IL-5 teve sua funcionalidade analisada. Este grupo utilizou um anticorpo anti-IL-5 para demonstrar a importância desta citocina, que se mostrou evidente pela supressão da inflamação e fibrose após o tratamento com o anticorpo bloqueador, impedindo a atividade funcional desta proteína. A fonte primária desta citocina descende de células mononucleares, em destaque as células $\mathrm{T}$ de padrão Th2, que também funciona como quimioatraente para eosinófilos que, por sua vez, também produzem fatores fibróticos como o próprio TGF- $\beta$ [80].

A IL-13, pertencente também ao grupo Th2 de citocinas, também é uma das citocinas chaves para o processo fibrótico se desenvolver. Juntamente com a IL-4, a IL-13 é igualmente capaz de estimular a proliferação e diferenciação de fibroblastos em miofibroblastos, bem como aumentar a expressão de a-actina de músculo liso e deposição de colágeno [81]. Outro estudo sugere que a IL-13 
poderia mediar efeitos fibróticos no pulmão e outros órgãos através da modulação de síntese de TGF- $\beta$ [82].

A IL-13 tem uma grande homologia com a IL-4, criando uma sinergia funcional entre estas duas citocinas em respostas de padrão Th2. Assim como a IL4, a IL-13 se liga à cadeia $\alpha$ do receptor de IL-4 (IL-4R $\alpha$ ), desencadeado a junção e sinalização de proteínas intracelulares, como as JAK, resultando na fosforilação do receptor. A STAT6 é então ativada e translocada para o núcleo onde pode se fixar nas regiões promotoras da IL-4/IL-13. O efeito pró-fibrótico da IL-13 foi demonstrado em modelo animal de fibrose pulmonar induzida pela bleomicina, na qual animais knockout para esta citocina tiveram níveis reduzidos de fibrose em relação a animais selvagens [83]. Desta forma, a literatura corrobora os dados deste trabalho, no qual foi encontrado um maior perfil Th2 quando há fibrose pulmonar.

A quantificação de IFN- $\gamma$ não demonstrou diferença nos grupos estudados. Os efeitos do IFN- $\gamma$ no desenvolvimento contrário à fibrose foram demonstrados através da administração desta molécula, causando a supressão de fibroblastos e promovendo efeito terapêutico [34; 35]. Assim, é sugerida a função imunomodulatória das células NKT pela sua característica de liberação massiva de todos os padrões de citocinas, podendo polarizar a favor ou contra o desenvolvimento da doença [24].

O TNF- $\alpha$ foi dosado e quantificado no tecido pulmonar para entender o nível de inflamação no tecido pulmonar. Esta citocina tem um papel central na inflamação e imunidade inata. No entanto, a produção de TNF- $\alpha$ é altamente regulada para evitar uma inflamação persistente e exagerada [62], o que pode explicar a concentração proteica estável após 14 dias de administração da droga.

Outra citocina que tem um papel importante na FPI é a IL-6. Esta proteína tem atividade multifuncional e pode desencadear um papel pró ou antiinflamatório através da ligação com seu respectivo receptor. O receptor na sua forma íntegra tem uma capacidade de ligação que abrange toda a família da IL-6: a GP130, também conhecida como IL-6ST, IL-6 $\beta$, ou CD130, forma um heterodímero com uma única cadeia $\alpha$, a IL-6R $\alpha$ tendo assim, atividade funcional. Após a associação citocina-receptor, uma cascata intracelular através das quinases JAK/STAT é desencadeada, ativando fatores nucleares da célula ativada [84]. A expressão e secreção desta citocina também abrange células que se relacionam 
diretamente com a patologia da FPI como macrófagos e fibroblastos pulmonares, assim como os próprios fibrócitos $[85 ; \mathbf{1 0 5}]$.

A literatura científica demonstra que a concentração de IL-6 aumentou no BAL de pacientes diagnosticados com FPI, quando comparados a pacientes controles [86]. Adicionalmente, a IL-6 demonstrou-se capaz de inibir a proliferação de fibroblastos em pulmões saudáveis; mas, por outro lado, teve papel mitogênico em pulmões com a FPI [87]. Um estudo subsequente do mesmo autor mostrou que a IL-6 foi capaz de induzir resistência a apoptose mediada por Fas em fibroblastos derivados de pulmões com FPI, através do aumento da proteína antiapoptótica Bcl-2. Neste mesmo estudo, a IL-6 foi capaz de deixar fibroblastos derivados de pulmões saudáveis mais sensíveis à indução de apoptose por Fas, aumentando a proteína pró-apoptótica Bax [88].

Recentemente, um grupo de pesquisadores identificou uma população diferente de fibroblastos em pulmões fibróticos que respondem de forma alternativa após a ligação da IL-6 com a GP130 [89], fato que se relaciona com todos os dados anteriores sobre a IL-6.

A literatura relata que a administração de sulfatídeo pode aumentar os níveis de IL-6 secretados por macrófagos [9o], fato que pode ajudar a explicar o porquê de não ter havido diferença estatística entre grupo WT BLM e grupo BLM+Sulfatídeo.

Como relatado, a administração da $\alpha$-galactosilceramida tem a capacidade de gerar uma resposta pró-inflamatória de perfil Th1, levando a níveis elevados de IL-6 [45]. Paralelamente, um trabalho científico demonstra que, após a administração da $\alpha$-GalCer, os níveis de IL-6 encontrados foram maiores que seu respectivo controle [91], fato que explica o nível relativamente alto da IL-6 encontrada no grupo de animais que recebeu esta substância juntamente com a bleomicina (Figura 13A).

O aumento de IL-10 também foi observado na avaliação da resposta imune após a estimulação por este mesmo agonista utilizado em outro modelo experimental [63]. Esta citocina tem grande potencial imunossupressor e pode modular negativamente tanto as respostas Th1 como Th2. A síntese desta molécula pode ser proveniente das células NKT [64], o que pode contribuir para o maior surgimento de células $\mathrm{T}$ regulatórias $\mathrm{FoxP}_{3}+$, demonstradas pelo aumento de 
quantificação do seu respectivo mRNA. Este conjunto imunoregulador é o que pode ter conferido a proteção a este grupo experimental.

A vimentina faz parte de uma família de filamentos intermediários, sendo a proteína mais importante e mais presente nas células mesenquimais e tem sido frequentemente usada como marcador no desenvolvimento de células e tecidos [65].

A análise experimental em camundongos knockout para esta proteína demonstrou que a vimentina participa em processos de cicatrização após injúrias teciduais, direcionando a migração de fibroblastos. A integridade vascular do endotélio, assim como a organização de proteínas envolvidas na adesão migração e sinalização celular, também está relacionada à expressão desta proteína [65]. A síntese da vimentina está relacionada à presença de fibroblastos, podendo funcionar como um bom marcador de alterações no comportamento celular, como a transição epitélio-mesenquimal [66].

Modelos experimentais corroboram os dados averiguados, demonstrando o aumento da expressão de vimentina em fibrose pulmonar induzida por metotrexato [67] e a exposição de células alveolares ao TGF- $\beta$ [68]. Este aumento pode ser um indicador da transição epitélio-mesenquimal através da presença de fibroblastos.

Diferente de qualquer outra questão que envolva nosso organismo, as células que compõem o sistema imune apresentam uma larga diversidade e centenas de subpopulações de uma mesma linhagem podem ser identificadas, como as células TCD4+ e TCD8+. No entanto, a identificação desta alta diversidade de células só pode ser feita através do uso da técnica de citometria de fluxo, que permite uma análise com múltiplos parâmetros, incluindo proteínas extracelulares e intracelulares [92].

O surgimento de novas técnicas e ensaios permitiu a quantificação de citocinas sintetizadas por células, além da análise de proteínas intracelulares fosforiladas, trazendo a atenção dos ensaios fenotípicos para a complexidade celular funcional que pode estar acontecendo. Diversas estratégias de análise e diferentes softwares para este fim podem ser utilizados [92].

Os resultados por citometria de fluxo quando analisadas com a quantificação total de citocinas no tecido pulmonar, sugere que as células TCD4+ medeiam parcialmente a regulação Th1/Th2. Por outro lado, na análise das células NKT não foi possível observar resultados significantes. 
Primeiramente, é interessante ressaltar que, após a estimulação antigênica das células NKT, o TCR invariante presente na superfície celular é regulado negativamente, tornando estas células anérgicas. Complementando este raciocínio, é clara a dificuldade no que condiz a identificação deste grupo nas primeiras 6-18 horas após sua ativação [25]. A amplificação do setor invariante do TCR destas células por PCR em tempo real não foi prejudicada e os resultados demonstram proliferação destas células (Figura 6) após 14 dias de administração do agonista agalactosilceramida. Contudo, é importante ressaltar que a volta da expressão extracelular do marcador NK1.1, usado para análise por citometria de fluxo, acontece muito depois que o TCR. Após a ativação celular, o marcador NK1.1 também é regulado negativamente; porém a não expressão desta proteína se prolonga por até 6 meses após a estimulação antigênica [25] tornando a análise das células NKT mais difíceis que outros grupos celulares.

As células $\mathrm{T}$ CD4+ se adaptam e amplificam suas respostas para coordenar suas respostas contra diferentes categorias de infecções e regular diversos tipos de células do sistema imune que pode afetar a fibrose [93].

Diversos estudos $[94 ; 95 ; 96]$ conectam o reparo tecidual e a própria fibrose com o perfil Th2 de células TCD4+, caracterizada pela síntese de citocinas típicas deste grupo, como IL-4 e IL-13, que atuam estimulando fibroblastos e iniciando a síntese de colágeno [93].

A quantificação total de IFN- $\gamma$ no tecido pulmonar não reflete totalmente o perfil de citocinas detectadas nas células T CD4+ e células NKT por citometria de fluxo, o que pode ser um indicativo de que outras células estão participando da mediação do microambiente pulmonar no padrão Th1/Th2. Além das células T CD4+, as células $\mathrm{T}$ CD8+, as células $\mathrm{NK}$ e as células $\mathrm{T} \gamma \delta$ podem participar do processo de síntese de IFN- $\gamma$ [97]. O mesmo aconteceu com a IL-4: a citocina presente no tecido está em alta concentração no grupo de animais selvagens que recebeu apenas bleomicina e apresenta elevado grau fibrótico. De forma análoga ao IFN- $\gamma$, outras células, como eosinófilos, basófilos, mastócitos e outras células da imunidade inata [98], podem estar produzindo a IL-4 ajudando na mediação de um micro ambiente que favoreça o aparecimento do processo fibrótico.

Após a análise do perfil Th1/Th2 no tecido pulmonar e a correlação com células que poderiam estar mediando este processo, nosso próximo passo foi 
avaliar o fenótipo dos macrófagos e observar se este perfil Th1/Th2 poderia estar influenciando a ativação da via clássica ou via alternativa.

Macrófagos M2 são descritos na literatura por serem induzidos através de citocinas padrão Th2, como IL-4 e IL-13, e são caracterizados pela produção de IL-10, arginase-1, FIZZ-1, CCL17, CD206, além de outros marcadores. No caso de uma pneumonia, uma resposta efetora contra a infecção necessita de um balanço na polarização do fenótipo dos macrófagos, sendo a indução de M1 necessária no estágio mais agudo, alterando seu fenótipo para M2 em modelos mais crônicos [69].

Os macrófagos M2 já foram descritos em casos de injúria muscular e hepática, além de estarem envolvidos em respostas fibróticas, fato que se relaciona diretamente com o presente trabalho [69]. A presença de macrófagos M2 foi observada em modelos experimentais de fibrose envolvendo tanto humanos quanto camundongos $[40 ; 70 ; 71]$, reforçando a hipótese de que o fenótipo M2 está envolvido no desenvolvimento da fibrose pulmonar.

O aumento de mRNA, envolvendo a infiltração e polarização para o fenótipos M2 em modelos de fibrose, também é descrito em modelos experimentais que utilizam camundongos selvagens, através da análise de MCP-1 e arginase-1 [44; 71], além da expressão de marcadores extra celulares, como o CD206 [40]. O dogma da transição fenotípica de M1 para M2 encontrado na literatura relata que, em processos de reparos teciduais, existe um predomínio de macrófagos M1 e, ao atingir um estágio cronificado, este fenótipo tende a polarizar para M2, justamente pelo ambiente de citocinas em que estas células estão envolvidas [72].

Após uma injúria, citocinas pró-inflamatórias, como IFN- $\gamma$, IL-12, IL-1 e TNF- $\alpha$, favorecem o surgimento do fenótipo M1. Estas citocinas também são expressas por esses macrófagos nas primeiras horas e dias após a lesão. Após 7 a 10 dias da lesão, a expressão de citocinas anti-inflamatórias começa a aumentar de concentração, favorecendo a transição fenotípica para M2 e contribuindo para a patologia da lesão enquanto aumenta a síntese de proteínas pró-fibróticas, como o TGF- $\beta$ [72].

A deleção específica da cadeia a do receptor de IL-4 reduziu significativamente a expressão de marcadores de M2, como FIZZ1 e arginase-1, reforçando a ideia de que um cenário de padrão Th2 favorece a polarização para este fenótipo celular. Seguindo esta lógica, a mudança fenotípica durante uma resposta de reparação tecidual com padrão Th2 aumenta progressivamente os 
marcadores de M2, de acordo com o tempo de progressão do reparo. Em modelo experimental humano de lesão de pele e modelo de lesão renal em camundongos, ambos apresentaram aumento da expressão de CD206 durante a progressão do reparo [72].

A literatura científica é bastante categórica no sentido de caracterizar e rotular os macrófagos em M1 e M2. Primeiro de tudo, é importante ressaltar que há uma grande discussão na atualidade que questiona a nomenclatura e rotulação destas células, gerando um conflito para quem trabalha com estas [99].

Em segundo lugar, é importante demonstrar que, apesar de existir um dogma de transição fenotípica de M1 para M2, estudos recentes demonstraram a presença híbrida de macrófagos com marcadores de M1 e M2 em modelo de reparação tecidual. Em algum ponto desta transição fenotípica, haverá expressão de marcadores dos dois fenótipos, bem como moléculas pró e anti-inflamatórias [100; 101; 102]. A plasticidade dos macrófagos é clara na literatura científica, sendo influenciada pelo microambiente em que se encontram. No entanto, a exposição a diferentes citocinas, como IFN- $\gamma$ e IL-4/IL-13, não induzem a uma diferenciação terminal, o que significa que os marcadores fenotípicos de M1 e M2 se alternam [103].

Com base na teoria científica encontrada e os dados no presente trabalho, é sugerido que o IL-4, presente no tecido no grupo selvagem que recebeu bleomicina, possa ter ativado os macrófagos presentes e induzido o aumento da via metabólica da arginase-1, levando a um fenótipo M2 [104]. No entanto, o marcador de M2 (CD206) não aumentou significativamente no tecido pulmonar como esperado, o que pode ser resultado do período analisado e relacionado a plasticidade dos macrófagos.

A arginase-1 está aumentada e foi dosada em nível transcricional, o que, posteriormente, será revertido em expressão proteica, no caso da CD206. Os macrófagos analisados por citometria de fluxo podem estar em constante processo de troca fenotípica, o que desvia o resultado esperado quando o CD86 e CD206 são analisados. 


\section{CONCLUSÃo}

- A bleomicina induz fibrose pulmonar em camundongos selvagens (WT BLM) de forma efetiva na concentração de $5 \mathrm{mg} / \mathrm{kg}$ em um período de 14 dias.

- A ausência ou ativação das células NKT levou a uma proteção ao desenvolvimento da fibrose pulmonar através da diminuição de citocinas de padrão Th2, transcritos pró-fibróticos causando menor deposição de colágeno.

- A mediação Th1/Th2 é em parte feita por linfócitos T CD4+, sendo detectado uma maior polarização de padrão Th2 quando a fibrose está presente.

- A presença da fibrose em uma resposta imune de padrão Th2 leva a polarização de macrófagos para o perfil M2 no tecido pulmonar.

- As células NKT participam no desenvolvimento da fibrose pulmonar; porém, o mecanismo pelo qual as células NKT protegem o pulmão da fibrose não está bem elucidado, sendo necessários estudos posteriores para melhor compreensão do processo. 


\section{REFERÊNCIAS ${ }^{*}$}

1. Zhang K, Phan SH. Cytokines and pulmonary fibrosis. BiolSignals. 1996;5:2329.

2. Marshall RP, Mcanulty RJ, Laurent GJ. The pathogenesis of pulmonary fibrosis: is there a fibrosis gene? Int $\mathrm{J}$ Biochem Cell Biol.1997;129:107-20.

3. Razzaque MS, Koji T., Harada T, Taguchi T. Localization in situ of type VI collagen protein and its mRNA in mesangial proliferative glomerulonephritis using renal biopsy sections. Histochem Cell Biol. 1999;111:1-6.

4. Razzaque MS, Foster CS, Ahmed AR. Tissue and molecular events in human conjunctival scarring in ocular cicatricial pemphigoid. Histol Histopathol. 2001;16:120312.

5. Mutsaers SE, Bishop JE, Mcgrouther G, Laurent GJ. Mechanisms of tissue repair: from wound healing to fibrosis. Int J Biochem Cell Biol. 1997;29:5-17.

6. Razzaque MS, Taguchi T. Cellular and molecular events leading to renal tubulointerstitial fibrosis. Med Electron Microsc. 2002;35:68-80.

7. American Thoracic Society and European Respiratory Society. Idiopathic pulmonary fibrosis: diagnosis and treatment. Am J Respir Crit Care Med. 2000;161:646-64.

8. Selman M, King TE, Pardo A. Idiopathic pulmonary fibrosis: prevailing and evolving hypotheses about its pathogenesis and implications for therapy. Ann Intern Med. 2001;134:136-51.

9. Chua F, Gauldia J, Laurent GJ. Pulmonary Fibrosis: searching for model answers. Amer Jour of Resp Cell and Molec Bio. 2005;33:9-13.

10. Swigris JJ, Brown KK. Fibrose Pulmonar, uma década de progressos. J Bras Pneumol. 2006;32(3):249-60.

11. Crystal RG, Bitterman PB, Mossman B. Future research directions in idiopathic pulmonary fibrosis: summary of a national heart, lung, and blood institute working group. Am J Respir Crit Care Med. 2002;166:236-46.

12. Coker RK, Laurent GJ. Pulmonary fibrosis: cytokines in the balance. European Respiratory Journal. 1998;11:1218-21.

13. Olson, AL, Swigris JJ. Idiopathic Pulmonary Fibrosis: Diagnosis and Epidemiology. Clin Chest Med. 2012;33:41-50.

14. Wynn TA. Integrating mechanisms of pulmonary fibrosis. $J$ Exp Med. 2011;208(7):1339-50.

\footnotetext{
* De acordo com:

International Committee of Medical Journal Editors. [Internet]. Uniform requirements for manuscripts submitted to Biomedical Journal: sample references. [updated 2011 Jul 15]. Available from:

http://www.icmje.org
} 
15. Pforte A, Gerth C, Voss A. Proliferating alveolar macrophages in BAL and lung function changes in interstitial lung disease. Eur Respir J. 1993;6:951-5.

16. Gharaee-Kermani M, Nozaki Y, Hatano K, Phan SH. Lung interleukin-4 gene expression in a murine model of bleomycin induced pulmonary fibrosis. Cytokine. $2001 ; 15: 138-47$.

17. Senoo H, Hata R. Extracellular matrix regulates and 1- ascorbic acid 2-phosphate further modulates morphology, proliferation, and collagen synthesis of perisinusoidal stellate cells. Biochem Biophys Res Commun. 1994;200:999-1006.

18. Zhang K, Gharaee-Kermani M M, McGarry B, Phan SH. In situ hybridization analysis of rat lung alpha 1 (I) and alpha 2 (I) collagen gene expression in pulmonary fibrosis induced by endotracheal bleomycin injection. Lab Invest. 1994;70:192-202.

19. Razzaque, MS, Taguchi T. The possible role of colligin/HSP47, a collagenbinding protein, in the pathogenesis of human and experimental fibrotic diseases. Histol Histopathol. 1999;14:1199-212.

2o. Moeller A, Ask K, Warburton D, Gauldia J, Kolb M. The bleomycin animal model: useful tool to investigate treatment options for idiopathic pulmonary fibrosis? Int $\mathrm{J}$ Biochem Cell Biol. 2008;40(3):362-82.

21. Adamson IYR. Drug-induced Pulmonary Fibrosis. Envirom Health Persp. $1984 ; 55: 25-36$.

22. Yamauchi K, Kasuya $Y$, Kuroda F, Tanka K, Tsuyusaki J, Ishizaki S, Matsunaga H, Iwamura C, Nakayama T, Tatsumi K. Attenuation of lung inflammation and fibrosis in CD69-deficient mice after intratracheal bleomycin. Resp Res. 2011;12:131.

23. Benitez SC. Bleomicina: um modelo de fibrosis pulmonar. Rev Inst Nal Enf Resp Mex. 2006;19(1):53-61.

24. Roman A, Rugeles MT, Montoya CJ. Papel de las células NKT invariantes en la respuesta inmune anti-viral. Colombia médica. 2006;37(2):159-68.

25. Kaer $\mathrm{LV}$, Parekh $\mathrm{VV}, \mathrm{Wu} \mathrm{L}$. Invariant natural killer $\mathrm{T}$ cells: bridging innate and adaptive immunity. Cell and Tissue Research. 2011;343(1):43-55.

26. Chiu YH, Jayawardena J, Weiss A, Lee D, Park SH, Dautry-Varsat A, Bendelac A. Distinct Subsets of CD1d-restricted T Cells recognize self- antigens loaded in different cellular compartments. J Exp Med. 1999;189(1):103-110.

27. Arrenberg P, Halder R, Kumar V. Cross-regulation between distinct natural killer T cells subsets influences immune response to self and foreign antigens. J Cell Physiol. 2009;218(2):246-50.

28. Jahng A, Maricic I, Aguilera C, Cardell S, Halder RC, Kumar V. Prevention of autoimmunity by targeting a distinct, noninvariant CD1d-reactive $\mathrm{T}$ cell population reactive to sulfatide. J Exp Med. 2004;199(7):947-57.

29. Halder RC, Aguilera C, Maricic I, Kumar V. Type II NKT cell-mediated anergy induction in type I NKT cells prevent inflammatory liver disease. J Clin Invest. 2007;117(8)2302-12.

3o. Ambrosino E, Terabe M, Halder RC, Peng J, Takaku S, Miyake S, Yamamura T, Kumar V, Berzosky JA. Cross regulation between Type I and Type II NKT cells in 
regulation tumor immunity: A new immunoregulatory axis. The Journal of Immunology. 2007;179(8):5126-36.

31. Cullery FJ. Natural killer cells in infection and inflammation of the lung. Immunology. 2009;128:151-63.

32. Fujii S, Motohashi S, Shimizu K, Nakayama T, Yoshiga Y, Taniguchi M. Adjuvant activity mediated by iNKT cells. Seminar in immunology. 2010;22:97-102.

33. Wu L, Gabriel CL, Parekh VV, Kaer LV. Invariant natural killer T cells: innate-like $\mathrm{T}$ cells with potent immunomodulatory activities. Tissue Antigens. 2009;73(6):535-45.

34. Strieter RM, Keane MP. Innate immunity dictates cytokine polarization relevant to the development of pulmonary fibrosis. The journal of clinical investigation. $2004 ; 114(2): 165-8$.

35. Kimura T, Ishii Y, Morishima Y, Shibuya A, Shibuya K, Tanaguchi M, Mochizuki M, Hegab AE, Sakamoto T, Normura A, Sekizawa K. Treatment with a-Galactosylceramide attenuates the development of Bleomycin-Induced Pulmonary Fibrosis. The journal of Immunology. 2004;172:5782-9.

36. Ricardo SD, Van Goor H, Eddy AA. Macrophage diversity in renal injury and repair. The Journal Clinical Investigation. 2008;118(11):3522-30.

37. Shapiro H, Lutaty A, Ariel A. Macrophages, Meta-Inflammation, and Immuno-Metabolism. The Scientific World Journal. 2011;11:2509-29.

38. Moreira AP, Hogaboam CM. Macrophages in allergic asthma: Fine-tuning their pro- and anti-inflammatory actions for disease resolution. Journal of Interferon \& Cytokine Research. 2011;31(6):485-91.

39. Casseta L, Cassol E, Poli G. Macrophage polarization in health and disease. The Scientific World Journal. 2011;11:2391-402.

40. Pechkovsky DV, Prasse A, Kollert F, Engel KMY, Dentler J, Luttman W, Friedrich K, Müller-Quernheim J, Zissel G. Alternatively activated alveolar macrophages in pulmonary fibrosis-mediator production and intracellular signal transduction. Clinical Immunology. 2010;137:89-101.

41. Khalil N, Whitman C, Zuo L, Danielpour, D, Greenberg A. Regulation of Alveolar Macrophage Transforming Growth Factor- $\beta$ Secretion by Corticosteroids in Bleomycininduced Pulmonary Inflammation in Rat. J. Clin. Invest. 1993;11:1812-8.

42. Raghow, R. Role of transforming growth factor- $\beta$ in repair and fibrosis. Chest. 1991;99:91-5.

43. Biernacka A, Dobaczewski $M$, Frangogiannis NG. TGF- $\beta$ signaling in fibrosis. Growth Factors. 2011;29(5):196-202.

44. Trujillo G, O'connor EC, Kunnel SL, Hogaboam CM. A novel mechanism for CCR4 in the regulation of macrophage activation in Bleomycin-induced pulmonary fibrosis. The American Journal of Pathology. 2008;172(5):1209-21.

45. Banchet-Cadeddu, A, Henon, E, Duachez M, Renault JH, Monneaux F, Haudrechy A. The stimulating adventure of KRN700. Org Biomol Chem. 2011;9(9):3080-104. 
46. Kwiecinski J, Rhost S, Löfbom L, Blomqvist M, Mansson JE, Cardell SL, Jin T. Sulfatide attenuates staphylococcus aureus sepsis through a CD1d- dependent pathway. Infec and Immun. 2013;81(4):1114-20.

47. Trujillo G, Hartigan AJ, Hogaboam CM. Treg cells and attenuated bleomycin induced fibrosis in lungs of ccr7-/- mice. Fibrog Tissue Repair. 2010;3:18.

48. Hirata H, Arima M, Fukushima $\mathrm{Y}$, Sugiyama K, Tokuhisa T, Fukuda T. Leukotriene aggravates bleomycin-induced pulmonary fibrosis. Respirology. 2013;18(4):674-81.

49. Zhao L, Wang X, Chang Q, Xu J, Huang Y, Guo Q, Zhang S, Wang W, Chen X, Wang J. Neferine, a bisbenzylisoquinline alkaloid attenuates bleomycin- induced pulmonary fibrosis. Eur Jour Pharmacol. 2010;627:304-12.

50. Ttrivedi R, Redente EF, Thakur A, Riches DWH, Kompella UB. Local delivery of biodegradable pirfenidone nanoparticles ameliorates bleomycin-induced pulmonary fibrosis in mice. Nanotechnology. 2012;23(50):505101.

51. Xiao JH, Zhang JH, Chen HL, Feng XL, Wang JL. Inhibitory effects of Isoliensinine on BLM-induced pulmonary fibrosis in mice. Planta Med. 2005;71(3):22530 .

52. Mouratis MA, Aidinis, V. Modelling pulmonary fibrosis with bleomycin. Curr Opin in Pulm Med. 2011;17:355-61.

53. Van Kaer L. Regulation of immune responses by CD1d-restricted natural killer T cells. Immunol Res.2004;30(2):139-53.

54. Godfrey DI, Kronenberg M. Going both ways - immune regulation via CD1d-dependent NKT cells. J Clin Invest. 2004;114(10):1379-88.

55. Rhost S, Sedimbi S, Kadri N, Cardell SL. Immunomodulatory type II Natural Killer T lymphocytes in health and disease. Scand J Immun. 2012;76(3):246-55.

56. Guru G, Hollinger MA, Giri SN. Regulation of transforming growth factor- $\beta 1 \mathrm{mRNA}$ expression by taurine and niacin in the bleomycin hamster model of lung fibrosis. Am $\mathrm{J}$ Respir Cell Mol Biol. 1998;18(3):334-42.

57. Hoyt DG, Lazo JS. Alterations in pulmonary mRNA encoding procollagens, fibronectin and transforming growth factor- $\beta$ precede bleomycin-induced pulmonary fibrosis in mice. J Pharmacol Exp Ter. 1988;246(2):765-71.

58. Warburton $\mathrm{D}$, Shi $\mathrm{W}, \mathrm{Xu}$ B. TGF- $\beta$ Smad3 signaling in emphysema and pulmonary fibrosis: an epigenetic aberration of normal development?. Am J Physiol Lung Cell Mol Physiol. 2013;304(2):83-5.

59. Zhao J, Shi W, Wang YL, Chen H, Bringas PJR, Datto MB, Frederick JP, Wang XF, Warburton D. Smad3 deficiency attenuates bleomycin- induced pulmonary fibrosis in mice. Am J Physiol Lung Cell Mol Physiol. 2002;282(3):585-93.

6o. Wynn TA. Fibrotic disease and the Th1/Th2 paradigm. Nat Rev Immunol. 2004;4(8):583-94.

61. Maier E, Duschl A, Horejs-Hoeck J. STAT6-dependent and independent mechanisms of th2 polarization. Eur J Immunol. 2012;42(11):2827-33. 
62. Sabio G, Davis RJ. TNF and MAP kinase signalling pathways. Semin Immunol. 2014;14.

63. Sharif S, Arreaza GA, Zucker P, Mi QS, Sondhi J, Naidenko OV, Kronenberg M, Koezuka Y, Delovitch TL, Gombert JM, Leite-De-Moraes M, Gouarin C, Zhu R, Hameg A, Nakayama T, Taniguchi M, Lepault F, Lehuen A, Bach JF, Herbelin A. Activation of natural killer $\mathrm{T}$ cells by a-galatosilceramide treatment prevents the onset and recurrence of autoimmune type 1 diabetes. Nat Med. 2001;7(9):1057-62.

64. Sonoda KH, Faunce DE, Taniguchi M, Exley M, Balk S, Stein-Streilein J. NK T cellderived IL-10 is essential for the differentiation of antigen-specific $t \mathrm{~T}$ regulatory cells in systemic tolerance. J Immunol. 2001;166(1):42-50.

65. Ivaska J, Pallari HM, Nevo J, Eriksson JE. Novel functions of vimentin in cell adhesion, migration and signaling. Exper Cell Res. 2007;313(10):2050-62.

66. Kokkinos MI, Wafai R, Wong MK, Newgreen DF, Thompson EW, Waltham M. Vimentin and epithelial-mesenchymal transition in human breast cancer observations in vitro and in vivo. Cells Tissues Organs. 2007;185:191-203.

67. Ohbayashi M, Kubota S, Kawase A, Kohyama N, Kobayashi Y, Yamamoto T. Involvement of epithelial-mesenchymal transition in methotrexato-induced pulmonary fibrosis. J Toxicol Sci. 2014;39(2):319-30.

68. Willis BC, Liebler JM, Luby-Phelps K, Nicholson AG, Crandall ED, Du Bois RM, Borok Z. Induction of epithelial-mesenchymal transition in alveolar epithelial cells by transforming growth factor-b1: potential role in idiopathic pulmonary fibrosis. Am J Pathol. 2005;166(5):1321-32.

69. Gharib SA, Johnston LK, Huizar I, Birkland TP, Hanson J, Wang Y, Parks WC, Manicome AM. MMP28 promotes macrophage polarization toward M2 cells and augments pulmonary fibrosis. J Leukoc Biol. 2014;95(1):9-18.

7o. Stahl M, Schupp J, Jäger B, Schmid M, Zissel G, MÜüller-Quernheim J, Prasse A. Lung collagens perpetuate pulmonary fibrosis via CD2O4 and M2 macrophage activation. Plos One. 2013;8(11).

71. Murray LA, Rosada R, Moreira AP, Joshi A, Kramer MS, Hesson DP, Argentieri RL, Mathai S, Gulati M, Herzog EL, Hogaboam CM. Serum amyloid P therapeutically attenuates murine bleomycin-induced pulmonary fibrosis via its effects on macrophages. Plos One. 2010;5(3).

72. Novak ML, Koh TL. Macrophages phenotype during tissue repair. J Leukoc Biol. 2013;93(6):875-81.

73. Eemoto M, Yoshida T, Fukuda T, Kawamura I, Mitsuyama M, Kita E, Hurwitz R, Kaufmann SH, Emoto Y. a-galactosilceramide promotes killing of Listeria monocytogenes within macrophage phagosome through invariant NKT-cell activation. Infect Immun. 2010;78(6):2667-76.

74. Hung LC, Lin CC, Hung SK, Wu BC, Jan MD, Liou SH, Fu SL. A synthetic analog of $\alpha-$ galactosilceramide induces macrophage activation via the TLR4- signaling pathway. Biochem Pharmacol. 2007;73(12):1957-70.

75. Zhang G, Nie H, Yang J, Ding X, Huang Y, Yu H, Li R, Yuan Z, Hu S. Sulfatideactivated type II NKT cells prevent allergic airway inflammation by inhibiting type I NKT 
cell function in a mouse model of asthma. Am $\mathrm{J}$ Physiol Lung Cell Mol Physiol. 2011;301(6):975-84.

76. Blomqvist M, Rhost S, Teneberg S, Lofbom L, Osterbye T, Brigl M, Mansson JE, Cardell SL. Multiple tissue-specific isoforms of sulfatide activate CD1d-restricted type II NKT cells. Eur J Immunol. 2009;39:1726-35.

77. Zhu T, Zhang W, Xiao M, Chen H, Jin H. Protective role of andrographolide in bleomycin-induced pulmonary fibrosis in mice. Int J Mol Sci. 2013;14(12):23581-96.

78. Jun D, Garat C, West J, Thorn N, Chow K, Cleaver T, Sullivan T, Torchia EC, Childs C, Shade T, Tadjali M, Lara A, Nozik-Grayck E, Malkoski S, Sorrentino B, Meyrick B, Klemm D, Rojas M, Wagner Jr DH, Majka SM. The Pathology of bleomycin induced pulmonary-fibrosis is associated with loss of resident lung mesenchymal stem cells which regulate effector t-cell proliferation. Stem Cells. 2011;29(4):725-35.

79. Kasper M, Barth K. Bleomycin and its role in inducing apoptosis and senescense in lung cells modulating effects of caveolin-1. Curr Canc Drug Targ. 2009;9:341-53.

8o. Gharaee-Kermani M, McGarry B, Lukacs N, Huffnagle G, Egan RW, Phan SH. The role of IL-5 in bleomycin-induced lung fibrosis. Jour of Leuk Bio. 1998;64(5):657-66.

81. Huaux F, Liu T, McGarry B, Ullenbruch M, Phan SH. Dual roles of IL-4 in lung injury and fibrosis. J Immunol. 2003;170(4):2083-92.

82. Lee CG, Homer RJ, Zhu Z, Lanone S, Wang X, Koteliansky V, Shipley JM, Gotwals P, Noble P, Chen Q, Senior RM, Elias JA. Interleukin-13 induces tissue fibrosis by selectively stimulating and activating transforming growth factor beta (1). J Exp Med. 2001;194(6):80921.

83. Liu T, Jin H, Ullenbruch M, Hu B, Hashimoto N, Moore B, McKenzie A, Lukacs NW, Phan SH. Regulation of found in inflammatory zone 1 expression in bleomycin-induced lung fibrosis: Role of IL-4/IL-13 and mediation via STAT-6. Jour of Immunol. 2004;173(5):342531.

84. Habiel DM, Hogaboam C. Heterogeneity in fibroblast proliferation and survival in idiopathic pulmonary fibrosis. Front Pharmacol. 2014;5(2).

85. Shahar I, Fireman E, Topilsky M, Grief J, Kivity S, Spirer Z, Ben Efraim S. Effect of IL6 on alveolar fibroblast proliferation in interstitial lung diseases. Clin Immunol Immunopathol. 1996;79(3):244-51.

86. Takizawa H, Satoh M, Okazaki H, Matsuzaki G, Suzuki N, Ishii A, Suko M, Okudaira H, Morita Y, Ito K. Increased IL-6 and IL-6 in bronchoalveolar lavage fluid (BALF) from patients with sarcoidosis: correlation with clinical parameters. Clin Exp Immunol. 1997;107(1):175-81.

87. Moodley YP, Scaffidi AK, Misso NL, Keerthisingam C, McAnulty RJ, Laurent GJ, Mutsaers SE, Thompson PJ, Knight DA. Fibroblasts isolated from normal lungs and those with idiopathic pulmonary fibrosis differ in interleukin-6/gp130-mediated cell signaling and proliferation. Am J Pathol. 2003;163(1):345-54.

88. Moodley YP, Misso NL, Scaffidi AK, Fogel-Petrovic M, McAnulty RJ, Laurent GJ, Thompson PJ, Knight DA. Inverse effects of interleukin-6 on apoptosis of fibroblasts from pulmonary fibrosis and normal lungs. Am J Respir Cell Mol Biol. 2003;29(4):490-8. 
89. Pechkovsky DV, Prêle CM, Wong J, Hogaboam CM, McAnulty RJ, Laurent GJ, Zhang SS, Selman M, Mutsaers SE, Knight DA. STAT3-mediated signaling dysregulates lung fibroblasts-myofibroblasts activation and differentiation in UIP/IPF. Am J Pathol. 2012;180(4):1398-412.

90. Popovic ZV, Sandhoff R, Sijmonsma TP, Kaden S, JennemannR, Kiss E, Tone E, Autschbach F, Platt N, Malle E, Gröne HJ. Sulfated glycosphingolipid as mediator of phagocytosis: SM4s enhances apoptotic cell clearance and modulates macrophage activity. Joun of Immunol. 2007;179:6770-82.

91. Tumurkhuu G, Koide N, Dagvadorj J, Morikawa A, Hassan F, Islam S, Naiki Y, Mori I, Yoshida T, Yokochi T. The mechanism of development of acute lung injury in lethal endotoxic shock using alpha-galactosylceramide sensitization. Clin Exp Immunol. 2008;152(1):182-91.

92. Lugli E, Roederer M, Cossarizza A. Data analysis in flow cytometry: the future just started. Cytometry A. 2010;77(7):705-13.

93. Barron L, Wynn TA. Fibrosis is regulated by Th2 nad Th17 responses and by dynamic interactions between fibroblasts and macrophages. Am J Physiol Gastroinest Liver Physiol. 2011;300(5):G723-8.

94. Chiaramonte MG, Dolnaldson DD, Cheever AW, Wynn TA. An IL-13 inhibitor blocks the development of hepatic fibrosis during a T-helper type 2 dominated inflammatory response. J Clin Invest. 1999;104:777-85.

95. Weng HL, Liu Y, Chen JL, Huang T, Xu LJ, Godoy P, Hu JH, Zhou C, Stickel F, Marx A, Bohle RM, Zimmer V, Lammert F, Mueller S, Gigou M, Samuel D, Mertens PR, Singer MV, Seitz HK, Dooley S. The etiology of liver damage imparts cytokine transforming growth factor beta1 or interleukin 13 as driving forces in fibrogenesis. Hepatol. 2009;50:230-43.

96. Wynn TA. Cellular and molecular mechanisms of fibrosis. J Pathol. 2008;214:199210.

97. Inoue S, Niikura M, Mineo S, Kobayashi F. Rolfes of IFN- $\gamma$ and $\gamma \delta$ T cells in protective immunity agains blood stage malaria. Front Immunol. 2013;4:258.

98. Allen JE, Sutherland TE. Host protective roles of type 2 immunity: parasite killing and tissue repair, flip sides of the same coin. Semin Immunol. 2014;14:60-8.

99. Murray PJ, Allen JE, Biswas SK, Fisher EA, Gilroy DW, Goerdt S, Gordon S, Hamilton JA, Ivashkiv LB, Lawrence T, Locati M, Mantovani A, Martinez FO, Mege JL, Mosser DM, Natoli G, Saeji JP, Schultze JL, Shirey KA, Sica A, Suttles J, Udalova I, Ginderachter JA, Vogel S, Wynn T. Macrophage activation and polarization: nomenclature and experimental guidelines. Immunity. 2014;14(1):14-20.

10o. Sindrilaru A, Scharffeter-Kochanek K. Disclosure of the culprits: macrophagesvesatile regulators of wound healing. Adv Wound CareI. 2013;2(7):357-68.

101. Sindrilaru A, Peters T, Wieschalka S, Baican C, Baican A, Peter H, Hainzl A, Schatz S, Qi Y, Schlecht A, Weiss JM, Wlaschek M, Sunderkotter C, Scharffeter-Kochanek K. An unrestrained proinflammatory M1 macrophage population induced by iron impairs wound healing in humans and mice. J Clin Invest. 2011;212(3):985-97.

102. Daley JM, Brancato SK, Thomay AA, Reichner JS, Albina JE. The phenotype of murine wound macrophages. J Leukoc Biol. 2010;87(1):59-67. 
103. Fernando MR, Reyes JL, Iannuzi J, Leung G, McKay DM. The pro-inflammatory cytokine IL-6 enhances the polarization of alternatively activated macrophages. Plos One. 2014;9(4):e94188.

104. Pourcet B, Pineda-Torra I.Transcriptional regulation of macrophage arginase 1 expression and its role in artherosclerosis. Trends Cardiovasc Med. 2013;23(5):143-52.

105. Chesney J, Metz C, Stavitsky AB, Bacher M, Bucala R. Regulated production of type I collagen and inflammatory cytokines by peripheral blood fibrocytes. $\mathrm{J}$ Immunol. 1998;160(1):419-25. 